\title{
POLYMER GRAFTING ONTO POLYURETHANE BACKBONE VIA DIELS-ALDER REACTION
}

M.Sc. THESIS

Soykan A ĞAR

\author{
Department of Chemistry \\ Chemistry Program
}

Thesis Advisor: Prof. Dr. Ümit TUNCA

JANUARY 2015 


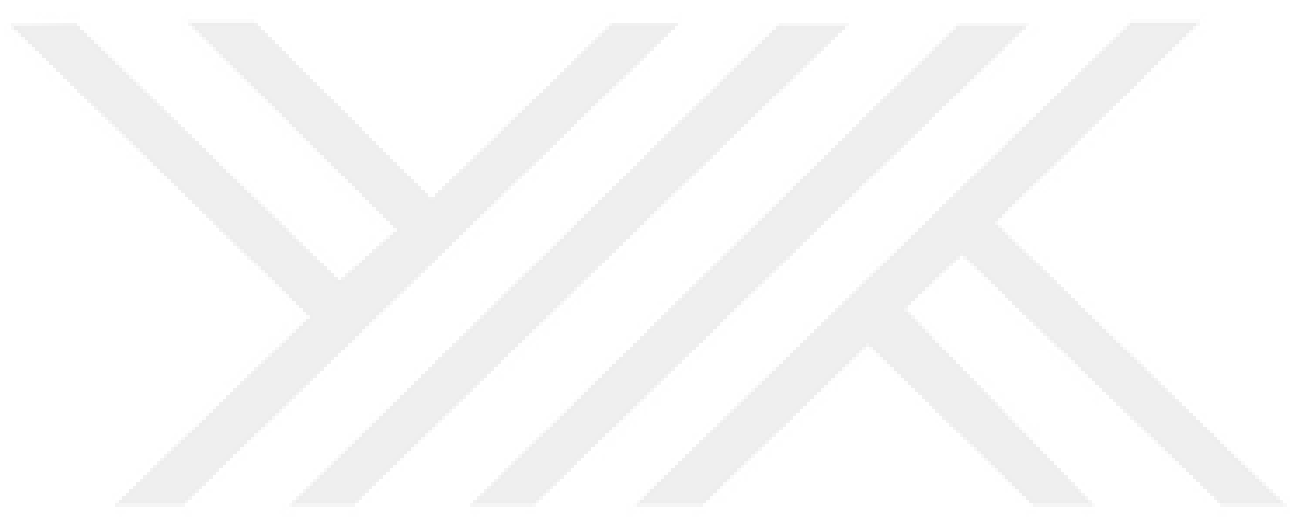




\title{
POLYMER GRAFTING ONTO POLYURETHANE BACKBONE VIA DIELS-ALDER REACTION
}

M.Sc. THESIS

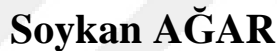

(509121029)

\author{
Department of Chemistry \\ Chemistry Program
}

Thesis Advisor: Prof. Dr. Ümit TUNCA

JANUARY 2015 


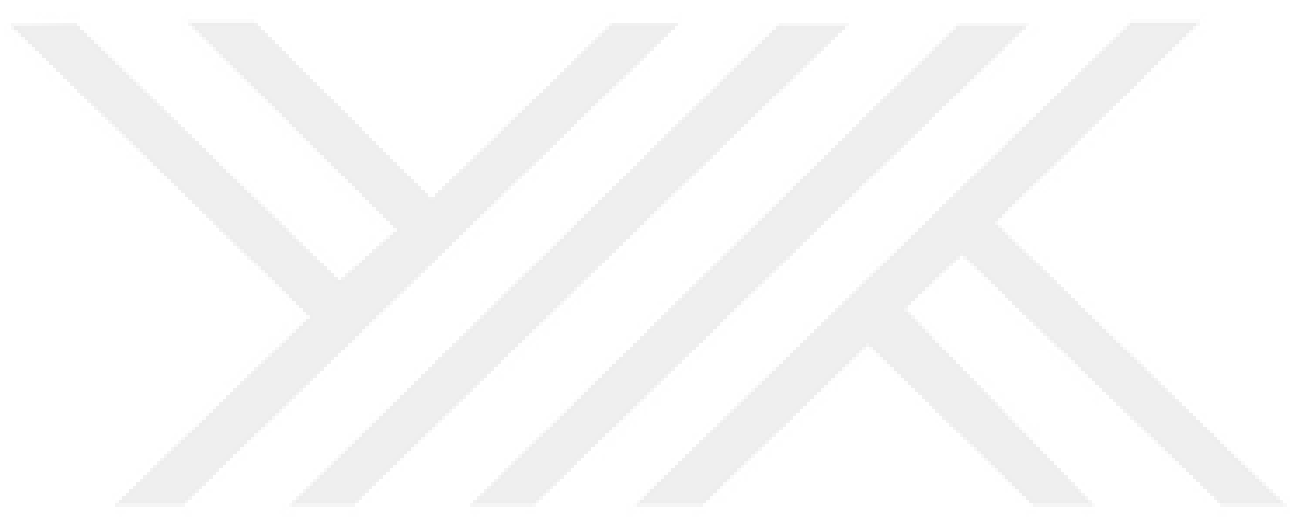


DIELS-ALDER KLİK TEPKIMMELERİ İLE POLIIÜRETAN GRAFT KOPOLIMERLERININ SENTEZI

\author{
YÜKSEK LISSANS TEZI \\ Soykan AĞAR \\ (509121029)
}

\author{
Kimya Anabilim Dalı \\ Kimya Programı
}

Tez Danışmanı: Prof. Dr. Ümit TUNCA

OCAK 2015 


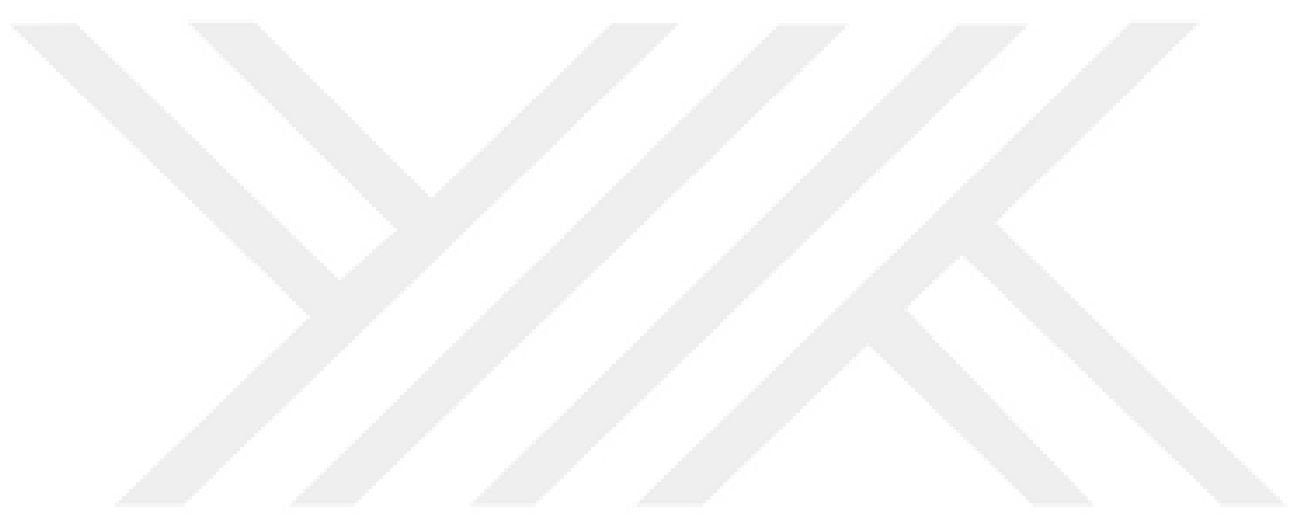


Soykan AĞAR, a M.Sc. student of ITU Graduate School of Science Engineering and Technology, with the student ID 509121029, successfully defended the thesis entitled "Polymer Grafting onto Polyurethane Backbone via Diels-Alder Reaction", which he prepared after fulfilling the requirements specified in the associated legislations, before the jury whose signatures are below.

Thesis Advisor : $\quad$ Prof. Dr. Ümit TUNCA

Istanbul Technical University

Jury Members : $\quad$ Prof. Dr. Gürkan HIZAL

Istanbul Technical University

Prof. Dr. Nergis ARSU

Yildız Technical University

Date of Submission : $\quad 01$ December 2014

Date of Defense : $\quad 21$ January 2015 
To my dear family and friends, 


\section{FOREWORD}

This master of science study has been carried out at Istanbul Technical University, Faculty of Science \& Letters, Department of Chemistry.

I would like to express my gratitude to my thesis supervisor Prof. Dr. Ümit TUNCA and my lab supervisor Assoc. Prof. Dr. Hakan DURMAZ and co-supervisor Prof. Dr. Gürkan HIZAL for offering invaluable help in all possible ways, continuous encouragement, and helpful criticisms throughout this research.

I would like to express my special thanks to Assoc. Prof. Dr. Hakan DURMAZ and M.Sc. Bilal Buğra UYSAL and my dear family for their helpful and understanding attitudes during my laboratory and thesis study at ITU. It has been a pleasure to work with them.

I would like to thank to buddies as well. It was really a great pleasure for me to know all of you. I am sure that we will always be in touch in the rest of our lives.

I would like to offer the most gratitude to my family for their patience, understanding and morale support during all stages involved in the preparation of this research. They are such wonderful human beings that they helped me to realize and achieve the goals I have dreamed.

December 2014

Soykan AĞAR

(Chemical \& Biological Engineer) 


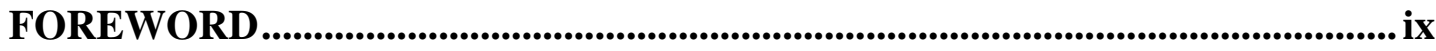

TABLE OF CONTENTS................................................................................... xi

ABBREVIATIONS ...........................................................................................................xiii

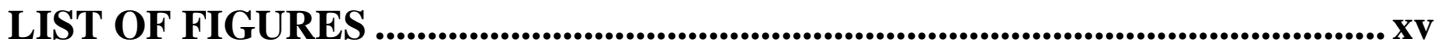

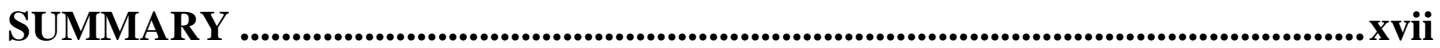

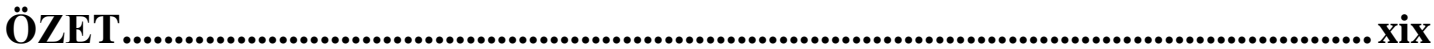

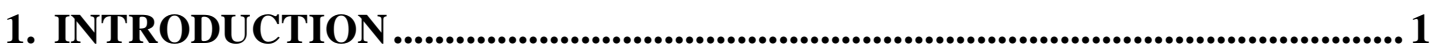

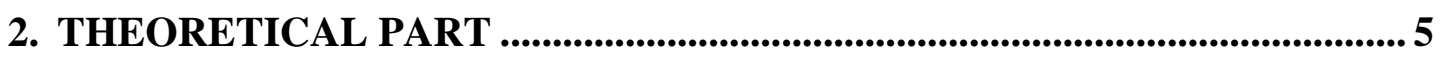

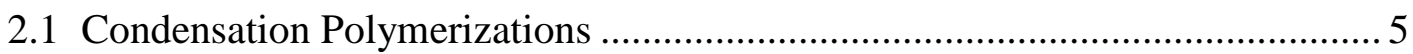

2.2 Controlled/“'Living”" Polymerizations .............................................................. 9

2.2.1 Atom Transfer Radical Polymerization (ATRP) ........................................ 11

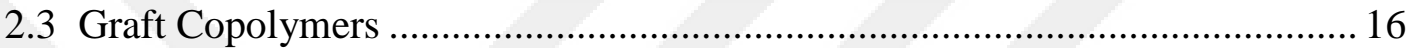

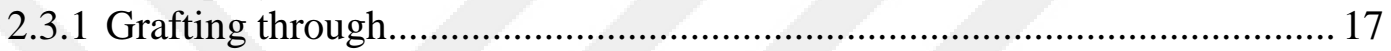

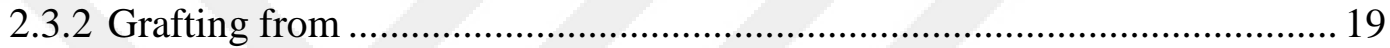

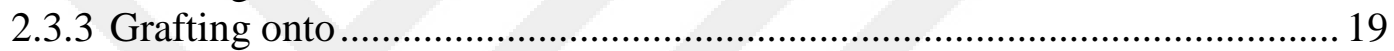

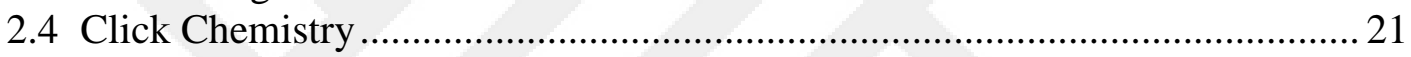

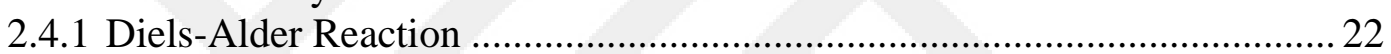

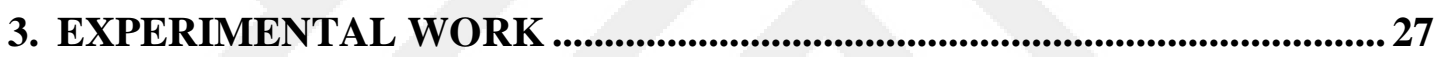

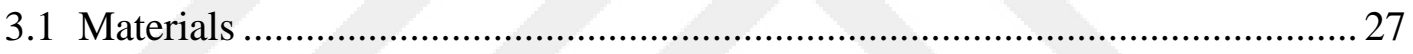

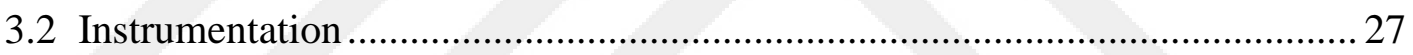

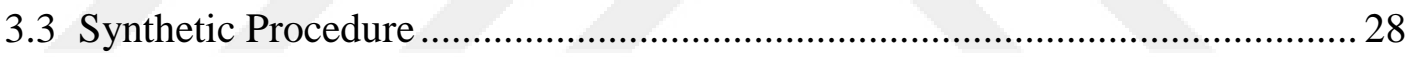

3.3.1 Synthesis of 2,2,5-trimethyl-[1,3]dioxane-5-carboxylic acid .................... 28

3.3.2 Synthesis of anthracen-9-ylmethyl 2,2,5-trimethyl-[1,3]dioxane-5-

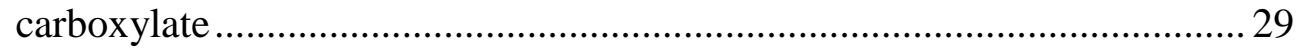

3.3.3 Synthesis of anthracen-9-ylmethyl 3-hydroxy-2-(hydroxymethyl)-2methylpropanoate ........................................................................ 29

3.3.4 Synthesis of pendant anthracene-functional polyurethane (PU-anthracene) via condensation polymerization

3.3.5 Synthesis of 4-(2-hydroxyethyl)-10-oxa-4-azatricyclo[5.2.1.02,6]dec-8-ene

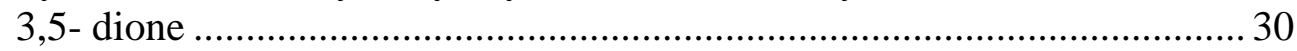

3.3.6 Preparation of furan-protected maleimide-end-functionalized PEG (PEG-

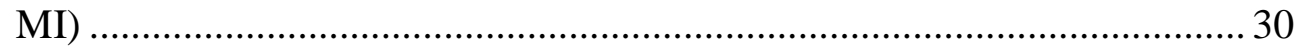

3.3.7 Preparation of furan-protected maleimide-end-functionalized PMMA (PMMA-MI)

3.3.8 Synthesis of Diels-Alder model reaction of PU-anthracene with 4-(2hydroxyethyl)-10-oxa-4-azatricyclo[5.2.1.02,6] dec-8-ene-3,5-dione, 2 (PUg-2).

3.3.9 Synthesis of PU-g-PEG copolymer via Diels-Alder reaction between PUanthracene and PEG-MI.

3.3.10 Synthesis of PU-g-PMMA copolymer via Diels-Alder reaction between

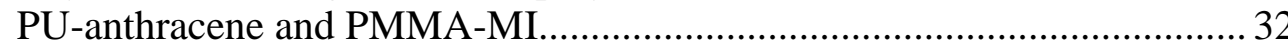

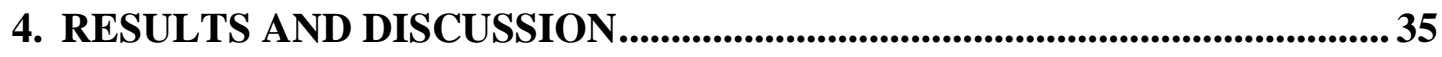

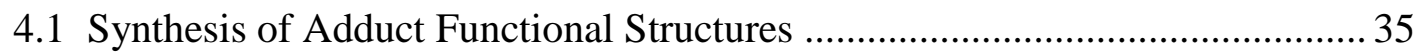

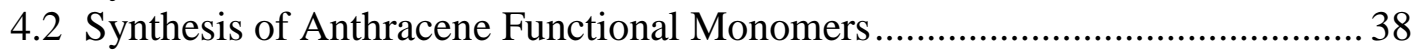

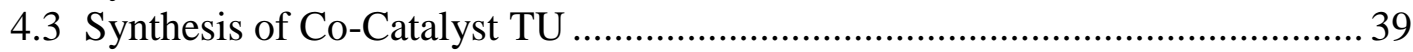


4.4 Homopolymers and Diels Alder Products 40

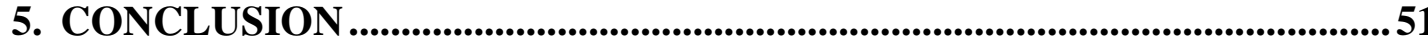

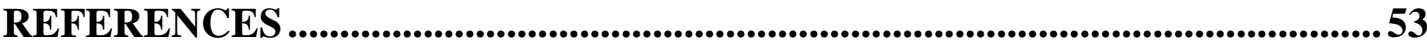

CURRICULUM VITAE .......................................................................................5 


\section{ABBREVIATIONS}

${ }^{1}$ H NMR : Hydrogen Nuclear Magnetic Resonance Spectroscopy

ATRP : Atom Transfer Radical Polymerization

$\mathbf{C H}_{2} \mathbf{C l}_{2}$ : Dichloromethane

$\mathrm{CHCl}_{3}$ : Chloroform

$\mathbf{C D C l}_{3}$ : Deutereated chloroform

DA : Diels-Alder

DBU : 1,8-diazabicyclo[5.4.0]undec-7-ene

DCM : Dichloromethane

DMAP : 4-dimethylaminopyridine

FPT : Freeze-Pump-Thaw

GPC : Gel Permeation Chromatography

PEG : Poly(ethyleneglycol)

PU : Poly(urethane)

PMMA : Poly(methylmetacrylate)

p-TSA : $p$-Toluenesulfonic acid

TGA : Thermogravimetric analysis

THF : Tetrahydrofuran

TU : Thiourea

TU/A : Thiourea/amine

UV : Ultraviolet 


\section{LIST OF FIGURES}

$\underline{\text { Page }}$

Figure 1.1 : General pathway of synthesis and modification of aliphatic polyurethane with pendant anthracene moieties (PU-anthracene)............ 3

Figure 2.1 : Two examples of synthetic condensation polymers...............................5

Figure 2.2 : Some Condensation Polymers.......................................................... 7

Figure 2.3 : Enhancement of crystallinity by hydrogen bonding ........................... 8

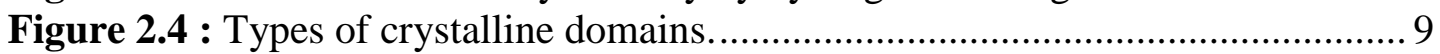

Figure 2.5 : The structure of an epoxy resin. ..................................................... 9

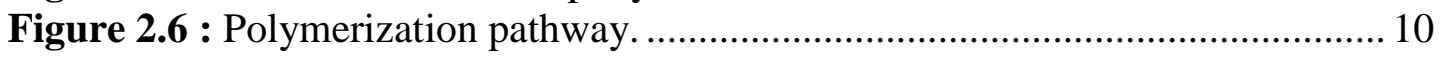

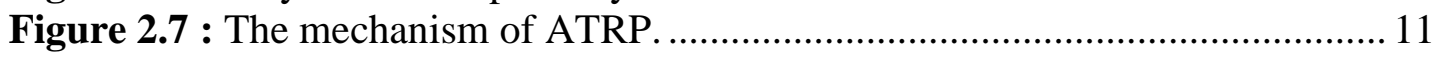

Figure 2.8 : The most common ligands for ATRP systems.................................. 16

Figure 2.9 : The "grafting-through" mechanism................................................. 17

Figure 2.10 : Homogeneous or heteregeous distribution of grafts......................... 18

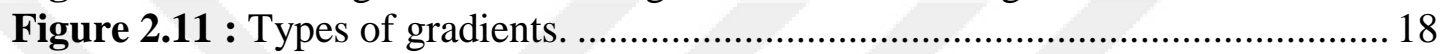

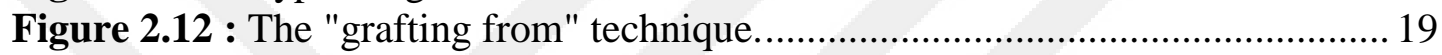

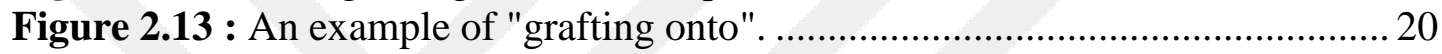

Figure 2.14 : A general notation of click chemistry. ............................................... 21

Figure 2.15 : A selection of reactions which match the criteria of Click Chemistry.22

Figure 2.16 : The mechanism of Diels-Alder reaction.......................................... 23

Figure 2.17 : General mechanism of Diels-Alder/retro Diels-Alder reactions of

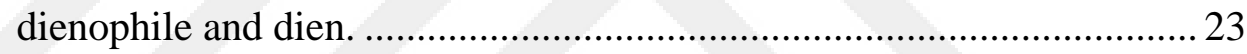

Figure 2.18 : Diels-Alder reaction's cis- and trans conformations.......................... 24

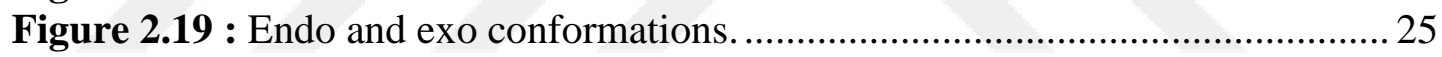

Figure 2.20 : Pi overlaps of endo - exo conformations....................................... 25

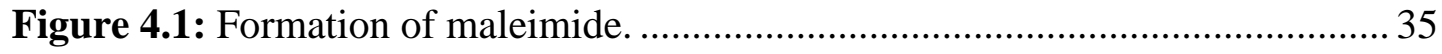

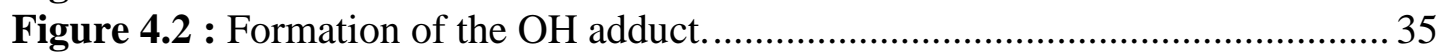

Figure 4.3 : The synthesis of 2-bromo-2-methyl-propionic acid 2-(3,5-dioxo-10-oxa4-azatricyclo[5.2.1.02,6]dec-8-en-4-yl) ethyl ester.............................. 36

Figure 4.4 : The synthesis of 4-(2-\{[(3-acetyl-7-oxabicyclo[2.2.1]heptyl)carbonyl] amino $\}$ ethoxy)-4-oxobutanoic acid.................................. 36

Figure 4.5 : Overlay 1H-NMR spectra of the compounds...................................... 37

Figure 4.6 : The synthesis of 1-(3,5-bis(trifloromethyl)phenyl)-3-

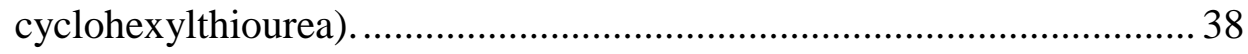

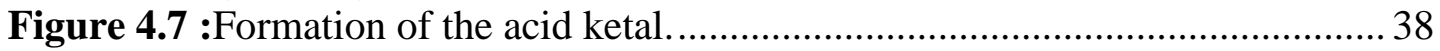

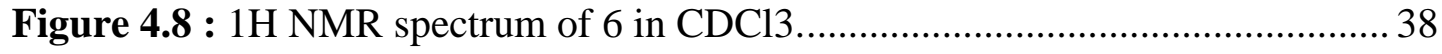

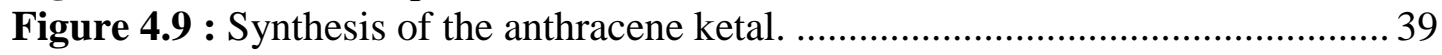

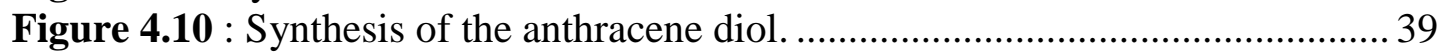

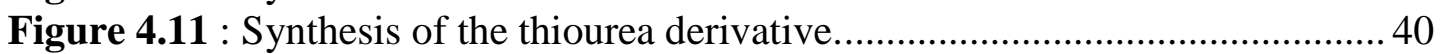

Figure 4.12 : 1H-NMR spectrum of 1-(3,5-bis(trifluoromethyl)phenyl)-3-cyclohexyl

thiourea (TU) in $\mathrm{CDCl} 3$ (500 MHz) .................................................. 40

Figure 4.13 : General reaction pathway for the synthesis of PU-graft copolymers. . 41

Figure 4.14 : 1H NMR spectra of PU-anthracene and PU-g-2 (model reaction) in $\mathrm{CDCl} 3(500 \mathrm{MHz})$.

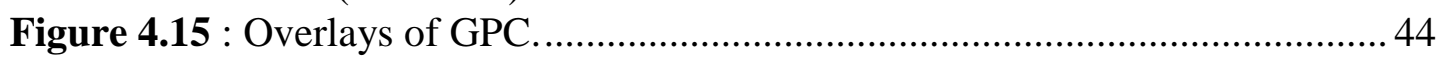

Figure 4.16 : 1H NMR spectrum of PU-g-PMMA copolymer in CDCl3 (500 MHz).

Figure 4.17 : 1H NMR spectrum of PU-g-PEG copolymer in CDCl3 (500 MHz). . 46 
Figure 4.18 : DSC thermograms of PU-anthracene, PU-g-2 (model reaction), and PU-g-PMMA copolymer at a heating rate of $10 \mathrm{oC} / \mathrm{min}$ in nitrogen....... 47

Figure 4.19 : UV spectra of PU-anthracene $(\mathrm{C} 0=0.033 \mathrm{~g} / \mathrm{L})($ at $0 \mathrm{~h}$ ) and PU-g-2 (at

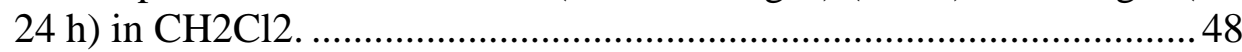

Figure 4.20 : GPC overlay of PU-anthracene and PU-g-2 (model react.) in THF. ... 48

Figure 4.21: UV spectra of $\mathrm{PU}$-anthracene precursor $(\mathrm{C} 0=0.033 \mathrm{~g} / \mathrm{L})($ at $0 \mathrm{~h})$, and

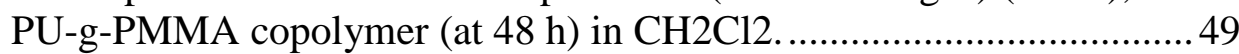

Figure 4.22 : UV spectra of PU-anthracene precursor $(\mathrm{C} 0=0.033 \mathrm{~g} / \mathrm{L})($ at $0 \mathrm{~h})$ and

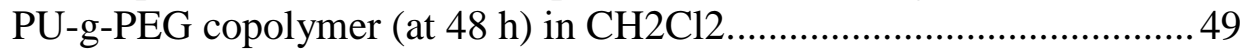

Figure 4.23 : TGA traces of PU-anthracene, PU-g-2 (model reaction), PU-g-PMMA copolymer and PU-g-PEG copolymer at a heating rate of $10 \mathrm{oC} / \mathrm{min}$ under nitrogen 


\title{
POLYMER-GRAFTING ONTO POLYURETHANE BACKBONE VIA DIELS-ALDER REACTION
}

\begin{abstract}
SUMMARY
Biocompatible, biodegradable, or bioresorbable polymers are constantly being used in biomedical and environmental applications, such as medical implants or drugdelivery systems. In terms of finding new technologies with the capability of having environmental friendly materials, it is paramount to seek new ways of improving the functionalities of polymers such as polyurethanes in this case. For that matter, since polyurethanes are an important class of polymers in the field of academy and industry, the development in that area would serve mankind a spectacular application branches in the field of medicine, autos, coatings, paintings and adhesives.

Aliphatic polyurethane with pendant anthracene moieties (PU-anthracene) were prepared from polycondensation of anthracen-9-yl methyl 3-hydroxy-2(hydroxymethyl)-2-methylpropanoate (anthracene diol) 1, with hexamethylenediisocyanate (HMDI) in the presence of dibutyltindilaurate (DBTL) in $\mathrm{CH}_{2} \mathrm{Cl}_{2}$ at room temperature for $10 \mathrm{~d}$.
\end{abstract}

Aliphatic polyurethane with a pendant anthracene group is employed as a backbone. The graft copolymers with regular graft points containing PU backbone combed with poly(methyl methacrylate) (PMMA) and poly(ethylene glycol) (PEG) side chains were simply achieved by a sequential polymer click reactions. The PU-anthracene $(\mathrm{Mn}, \mathrm{GPC}=12900 \mathrm{~g} / \mathrm{mol}, \mathrm{Mw} / \mathrm{Mn}=1.87$, relative to PS standards $)$ was clicked with a linear $\alpha$-furan protected-maleimide terminated-poly(methyl methacrylate) (PMMAMI) $(\mathrm{Mn}, \mathrm{GPC}=2500 \mathrm{~g} / \mathrm{mol}, \mathrm{Mw} / \mathrm{Mn}=1.33)$, or -poly(ethylene glycol) $(\mathrm{PEG}-\mathrm{MI})$ (Mn,GPC $=550 \mathrm{~g} / \mathrm{mol}, \mathrm{Mw} / \mathrm{Mn}=1.09)$, to result in well-defined PU-graft copolymers, PU-g-PMMA (Mn,GPC $=23800 \mathrm{~g} / \mathrm{mol}, \mathrm{Mw} / \mathrm{Mn}=1.65$, relative to PS standards) or PU-g-PEG (Mn, GPC $=11600 \mathrm{~g} / \mathrm{mol}, \mathrm{Mw} / \mathrm{Mn}=1.45$, relative to PS standards) using Diels-Alder reaction in dioxane/toluene at $105{ }^{\circ} \mathrm{C}$, have gained increasing interest for their potential use in biomedical and pharmaceutical applications due to their favorable biocompatibility, biodegradability, and nontoxicity. The Diels-Alder grafting efficiencies were found to be over 93-99\% using UV spectroscopy. Moreover, the structural analyses and the thermal transitions of all copolymers were determined via ${ }^{1} \mathrm{H}$ NMR, DSC and TGA, respectively. It was found out that all the graft structures including the model (PU-g-Adduct Alcohol, PU-g-PEG, PU-g-PMMA) were fitting with the results of ${ }^{1} \mathrm{H} N M R, \mathrm{UV}, \mathrm{DSC}$ and TGA. With respect to the UV Diels-Alder efficiencies of those mentioned grafts were found to be in the range of $93-99 \%$. This vindicates the success of the yields of graft.

In terms of technological aspects and future work, one can assume that, grafts onto Polyurethane backbone might have significant improvements in the stress vs strain graph. PMMA has the durability, PEG has the hydrophilicity and PU has the elasticity and toughness. When these are combined in the stress vs strain graph, an elastic, tough, strong, heat resistant (due to higher Tg points of DSC) combed like polymer structure is seen to be formed. 


\title{
DIELS-ALDER CLICK TEPKIMMELERİ İLE POLIÜRETAN GRAFT KOPOLIMERLERININ SENTEZI
}

\begin{abstract}
ÖZET
Biyouyumlu, biyodegrede olabilen ve çözünebilen polimerler, biyomedikal ve çevre bilimi alanlarındaki yüksek uygulanabilirlikleri ve kullanılabilirlikleri sayesinde medikal implantlarda ve ilaç kimyasında vücuda taşıyı vektörler olarak kullanılması hususunda önemli yer almaktadırlar. Çevreye uyumlu ve zarar vermeyen yeni teknolojilerin keşfedilebilmesi için polimerlerin bir kolu olan poliüretanların fonksiyonlarının geliştirilmesi çok önemlidir. Poliüretanlar akademi ve sanayi tarafından çalışılan ve önem arzeden polimerler olduğundan ötürü, bu gelişim, teknolojinin farklı farklı alanlarında (otomotiv, medikal, kaplamalar, boya, adhesivler vb.) kullanılan poliüretanların insanlığa daha iyi hizmet etmesinde rol oynayacaktır.
\end{abstract}

$\mathrm{Bu}$ manada, mekanik özellik bakımından daha dayanıklı, daha sert ve sertliğine rağmen elastisitesini koruyabilen yeni graft polimerler üretmek ve bunları sanayiye uyarlayabilmek büyük önem arz etmektedir. Sentezi yapılan yeni bir tip graft veya tarak kopolimerin, doğru sentezlendiğine ve yeni özellikler kazandığına dair ikna edici sonuçlar vermesi gerekmektedir. Proton NMR'1 bilinen en yaygın yöntem olmakla beraber bunu, bu tezde uygulanan UV ölçümü, GPC, DSC ve TGA gibi diğer yöntemler de takip etmelidir.

Antrasen gruplu alifatik poliüretanın sentezi genellikle literatürde bilindiği üzere isosiyanat ve diol grubu olan iki reaktant arasında gerçekleşip, step (kademeli) polimerleşme sınıfı altında yer almaktadır. Genellikle step (kademeli) polimerleşmede küçük bir molekülün eliminasyonu gerçekleşir. Bu çoğunlukla su gibi bir molekül olmasına karşın, bu çalışmada hiçbir yan ürün ve küçük molekül ortaya çıkmamıştır.

Poliüretanın karbamat gövdesini oluşturmak için, antrasen diol, hekzametilen diizosiyanat tercih edilmiştir. $\mathrm{Bu}$ reaktantların tepkimesi dibütiltindilaurat ile diklorometan çözücüsü içinde 10 gün süren kondenzasyon polimerleşmesi ile sentezlenmiştir. Süreç boyunca, polimerleşme tepkimesi oda sicaklığına sabitlendi. Sonuçlar çekilen proton NMR'ında bakıldığında en önemli olan isosiyanat ucuna bağlı $\mathrm{CH}_{2}$ 'deki hidrojenlerin, diğer uçtaki $\mathrm{OH}$ grubunun hidrojeninin ve de antrasenin piklerinin kusursuzca spektrumda var olduğu görüldü. Çekilen UV de elin parmaklarını andıran özel antrasen eğrisinin varlığı ve DSC'deki $72,9{ }^{\circ} \mathrm{C}$ 'lik $\mathrm{Tg}$ noktasının gözlemlenmesi bunu destekledi. TGA sonuçlarına göre ise yapının 200 ${ }^{\circ} \mathrm{C}$ 'den sonra bozunuyor olması yine destekleyici bir unsurdu.

Antrasen gruplu alifatik poliüretan homopolimeri, Diels-Alder ile oluşacak graft kopolimer için omurga olarak kullanıldı. Alifatik poliüretan omurgasına, ardışık polimer klik tepkimeleriyle poli(metil metakrilat) (PMMA) ve poli(etilen glikol) (PEG) başarıyla eklenerek tarak şeklinde graft kopolimer yapısı oluşturulmuştur. Tepkimeye BHT eklenerek, $105{ }^{\circ} \mathrm{C}$ gibi yüksek bir sicaklıkta oluşabilecek ortam radikalleri giderilmiştir. PU-antrasen $(\mathrm{Mn}, \mathrm{GPC}=12900 \mathrm{~g} / \mathrm{mol}, \mathrm{Mw} / \mathrm{Mn}=1.87$, PS standardlarına göre), $\alpha$-furan korumalı maleimid uçlu poli(metil metakrilat) (PMMAMI) $(\mathrm{Mn}, \mathrm{GPC}=2500 \mathrm{~g} / \mathrm{mol}, \mathrm{Mw} / \mathrm{Mn}=1.33)$ ile ve $\alpha$-furan korumalı maleimid uçlu poli(etilen glikol) (PEG-MI) $(\mathrm{Mn}, \mathrm{GPC}=550 \mathrm{~g} / \mathrm{mol}, \mathrm{Mw} / \mathrm{Mn}=1.09)$ ile büyüklüğü 
ve bağlanma yeri kesin olarak bilinecek şekilde Diels-Alder reaksiyonuna dioksan/toluen çözücü varlığında bağlanmıştır. Bilindiği üzere Diels Alder tepkimelerinin yüksek sıcaklıkta yüksek verimle gerçekleşiyor olması nedeniyle deneyde de $105^{\circ} \mathrm{C}$ kullanılmıştır. Daha yüksek sıcaklığa çıkılabilmesi mümkün iken, dioksanın kaybını önlemek amacıyla bu sıcaklık optimum olarak seçilmiştir. Neticesinde PU-g-PMMA (Mn,GPC $=23800 \mathrm{~g} / \mathrm{mol}, \mathrm{Mw} / \mathrm{Mn}=1.65$, PS standardlarına göre) ve PU-g-PEG $(\mathrm{Mn}, \mathrm{GPC}=11600 \mathrm{~g} / \mathrm{mol}, \mathrm{Mw} / \mathrm{Mn}=1.45$, PS standardlarına göre) oluşmuştur. PU-g-PMMA tepkimesinin veriminin çok yüksek olması ve saflaştırma sonrasında dahi $90 \%$ gibi bir oranda eldenin olması kontrollü yaşayan radikal polimerizasyon türlerinden biri olan ATRP'nin kullanılması ile mümkün olmuştur. PU-g-PMMA'in metil metakrilat tarafindan uç grubu $\mathrm{Cl}$ ile bitmektedir. Br yerine Cl'un uç grup olmasının sebebi, hem Bromun çok iyi bir ayrılan grup olması ve dolayısıyla ara basamaklardaki yapıda dursa bile, son yapıda uçta kalamayıp ayrılması ve de hem de $\mathrm{Cu}(\mathrm{I}) \mathrm{Cl}$ 'ün katalizör olarak kullanılmış olması sebebiyledir. Burada tek dezavantaj, $\mathrm{Cl}$ gibi bir uç gruplu grafta sahip olmaktır. Yalnız bu durum çok basit bir post polimerizasyon modifikasyonu ile giderilebileceği için bu konuda tez içerisinde bir adım daha yapılması gerekli görülmemiştir.

Diels-Alder graft kopolimer verimi, ultra viyole spektroskopisinde yüzde 93 ile 99 arası gibi yüksek bir değerde bulunmuştur. Kopolimerlerin yapı analizleri ${ }^{1} \mathrm{H}$ NMR ile, termal geçiş diyagramları ise DSC ve TGA ile sorunsuz olarak tayin edilmiştir. UV sonuçlarındaki Diels-Alder sonuçlarının verimlerinin bu denli yüksek olması çok büyük bir başarıdır. Bunu desteklemek maksatlı çekilen DSC diyagramlarında görülmüştür ki, PU'nun kendi Tg noktası olan 72,9'dan daha büyük değerler elde edilen graft kopolimerler, hem yapı olarak daha farklı davrandıklarını hem de 1sıya karşı daha yüksek direnç gösterdiklerini ispatlamışlardır. TGA diyagramında bambaşka eğrilere sahip oluşları yine yapıların farklı olduğunu yani Diels-Alder tepkimesinin gerçekleştiğini ispatlarken, bir yandan da külleştirme sırasındaki Retro Diels-Alder hakkında da bizlere bilgi vermektedir. Antrasen-maleimid arasındaki Retro Diels-Alder $200{ }^{\circ} \mathrm{C}$ 'den sonra gerçekleşmiştir.

${ }^{1} \mathrm{H}$ NMR spektrum piklerindeki en karakterize pikler olan polimer tekrar eden birimi hidrojenleri, antrasen hidrojenleri ve poliüretan omurga uç grup hidrojenleri sorunsuzca belirmiş ve yapılar ispatlanmıştır. Bunu takiben graftlarda, aynı UV'de olduğu gibi ${ }^{1} \mathrm{H}$ NMR'ında da antrasen pikleri aromatik bölgede kaybolmuştur.

GPC sonuçları ise PMMA'in graftının poliüretana normalde de olması gerektiği gibi poliüretan homopolimere oranla daha solda çıkarmıştır. GPC kolonuna tutunmadan hızlıca akıp geçen büyük PU-g-PMMA polimerleri kolonu erkenden terk edip, zaman eğrisinde solda çıkmıştır. Bu durum PU-g-PEG'de ters olmuştur. Sebebi ise PEG in hidrodinamik hacminin küçük olmasının onun kolona ve kolonun küçük keselerine tutunmasını arttırmış ve sanki küçük bir molekül kolonu geç terkediyor gibi bir izlenim yaratmıştır. Polistiren standartları bu datada böyle bir değişiklik yapmıştır ama netice kolayca bu şekilde anlaş1labilmektedir.

Konunun sanayiye uyarlanabilirlliğini ele almak gerekirse, biyomedikal ve ilaç kimyası alanlarında önemli sayılacak olan biyoçözünürlük, biyouyumluluk ve toksik olmayan özelliklere sahip olması yönünde geliştirilme yapılmış olmasıdır. $\mathrm{Bu}$ uyumun olmasını olası mekanik özelliklerin gelişimine ait ipuçları bizlere göstermektedir. Gerilme-defromasyon eğrisi genellikle teknolojik veya sanayi değerlendirmeler için kullanılmaktadır. PMMA gibi bir sert malzemenin, PU gibi bir 
elastic ve amorf bir polikondenzasyon polimerinin graft olarak birleşip hem elastic hem de güçlü bir polimer olması sanayi anlamında çok büyük önem arz etmektedir. PEG graftının ise düşük hidrodinamik hacmi, onu gerekli görülen viskoz alanlarda küçük ve dayanıklı kılabilecekken, aynı zamanda PEG'in hidrofilik özelliği yani suyu sevmesi, onun başlı başına kullanımına çok büyük katkı sağlayacaktır. Bu tarz dallı, taraklı polimerler bu tip özelliklerle tıbbi alanlarda etkin şekilde kullanılmaktadırlar ve bu tezdeki graftlar da yine bu yönde adımlar atabilir. İlaç kapsüllerinin PEG'in hidrofilik yapısında olması gibi veya dallı olan bu graftların hücre içerisinde yanlış katlanmış olan büyük tomarlar halindeki proteinleri tutup çekip çıkardığını öngörmek Parkinson, Alzheimer, ALS, Huntington gibi nörodejeneratif hastalıkların önüne geçmeyi dahi sağlayacaktır. Dolayısıyla hem tıpla hemde genetik ve biyoteknolojiyle birleşik multi disipliner çalışmalar yapılabilecektir. Polimer kimyasının bu geniş yelpazede kullanılabilir olması bu alanın önünün daha çok açık olduğunu ve yeni gelişmelere gebe olduğunu bizlere bir kez daha göstermektedir.

Aynı şekilde gelecekte bu konunun gidebileceği bir alan olan kalp pilleri ve kateterlerin graft kopolimer yapıları bir hayli önemlidir. Vücuda uyumlu, toksik olmayan taraklı kopolimerler geliştirmek ve bunları ucuz maliyetle yapabilmek Diels-Alder Klik kimyası gibi bir kimyanın sayesinde olacaktır.

Çevre Bilimi ve Mühendislik'inde de aynı şekilde toksiklikten uzak bu tarz yöntemler etkili bir biçimde kullanılabilir. 


\section{INTRODUCTION}

Polyurethanes (PUs) demonstrate an important class of polymers for the field of academy and industry [1]. The most popular applications of PUs are in the field of medicine, automobiles, coatings, paintings, and adhesives. The diol-diisocyanate based condensation polymerization has still been the most versatile method for the synthesis of PU despite the fact that isocyanate-free routes are available [2]. While the most of PUs are thermoset, thermoplastic PUs have found a wide range of applications because the mechanical, thermal, and chemical properties can be modified by the chemical nature and composition of the starting compounds [1]. The easiest way to introduce functionalities onto the PU chain is to use functionalized precursors $[2,3]$. Here, much attention has been paid to the functional diols since most of the commercialized diisocyanates do not contain suitable functionalities [35]. Even though the functional diols are commercially available, these functional groups generally need to be protected during the polymerization and should be removed afterwards [3-5]. As a result, protection and subsequent deprotection steps are not convenient. Therefore, it is a great challenge to prepare functionalized diols, which will be used in the preparation of PU, since they stay inert during the polymerization and allow efficient side chain modification of PU after the polymerization [3-5]. The "click" reactions mostly fulfill these requirements for the synthesis of side chain- functionalized PUs based on diols with clickable functional groups [5-12]. Among click reactions, copper catalyzed azide-alkyne cycloaddition (CuAAC) [4, 5], Michael thiol-ene [6], thiol-ene [7, 8], thiol-yne [9], nucleophilic substitution on perfluorophenyl ester [10], and Diels-Alder [11, 12] have been recently employed for the synthesis of side chain-functional PUs. In recent times, the Du Prez group, for the first time, reported an efficient preparation of side chainfunctionalized linear PUs by reacting the one of two types of alkyne-functionalized diols (together with butandiol) and hexamethylenediisocyanate (HMDI) [4, 5]. Subsequently, alkyne-functionalized PU was clicked to a variety of azide compounds via $\mathrm{CuAAC}$, either catalyzed by $\mathrm{CuBr} / N, N, N^{\prime}, N^{\prime}, N^{\prime \prime}$-pentamethyldiethylenetriamine (PMDETA) or $\mathrm{CuSO}_{4} .5 \mathrm{H}_{2} \mathrm{O} /$ sodium ascorbate in $N, N$-dimethyl formamide (DMF), 
or dimethyl sulfoxide (DMSO) at $50^{\circ} \mathrm{C}$ affording side chain-functionalized PUs having various degrees of functionalization. Moreover, the Du Prez group prepared PUs with clickable side chain groups, i.e. alkene, maleimide, and alkynes, and allowed to react with thiols using the Michael thiol-ene [6], thiol-ene [7b], and thiolyne [9] reactions, respectively, in order to quantitatively incorporate various functionalities. However, the Diels-Alder reaction in the PU chemistry is limited to a specific type of application based on the exploitation of the thermally reversible nature of the Diels-Alder reaction between furan and maleimide [11, 12]. The Wang group produced a linear PU with Diels-Alder bonds and demonstrated the selfhealing property of this PU under thermal treatment [11]. The self-healing efficiency was determined to be up to $80 \%$. More recently, Du Prez employed Diels-Alder reaction for the preparation of furan-based thermoset PUs having a self-healing property [12]. In this regard, the diol with one furan functionality was first clicked with bis(maleimide) to yield a Diels-Alder adduct as a cross-linker and subsequently reacted with HMDI together with a poly(e-caprolactone) (PCL) diol in order to give the final thermoset polyurethane in a one-pot reaction. The self-healing system operates in the cycles of retro-Diels-Alder and Diels-Alder at 100 and $40{ }^{\circ} \mathrm{C}$, respectively. In this work, we studied here a different application of the Diels-Alder reaction in PU chemistry. We intended to incorporate linear polymer precursors to the PU backbone with the anthracene pendant units through Diels-Alder reaction. The linear aliphatic PU with the anthracene pendant groups was first prepared and subsequently $\alpha$-furan-protected-maleimide terminated-linear poly(ethylene glycol) (PEG) and poly(methyl methacrylate) (PMMA) precursors were introduced into this PU backbone to yield corresponding graft copolymers, PU-g-PEG and PU-g-PMMA via Diels-Alder reaction. 
<smiles>O=C=NCCCCCCN=C=O</smiles><smiles>O=C(OCc1c2ccccc2cc2ccccc12)C(CO)(CO)CO</smiles>

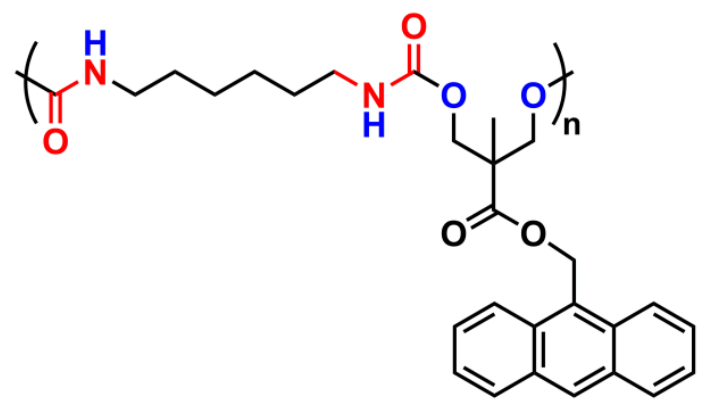

PU-Anthracene

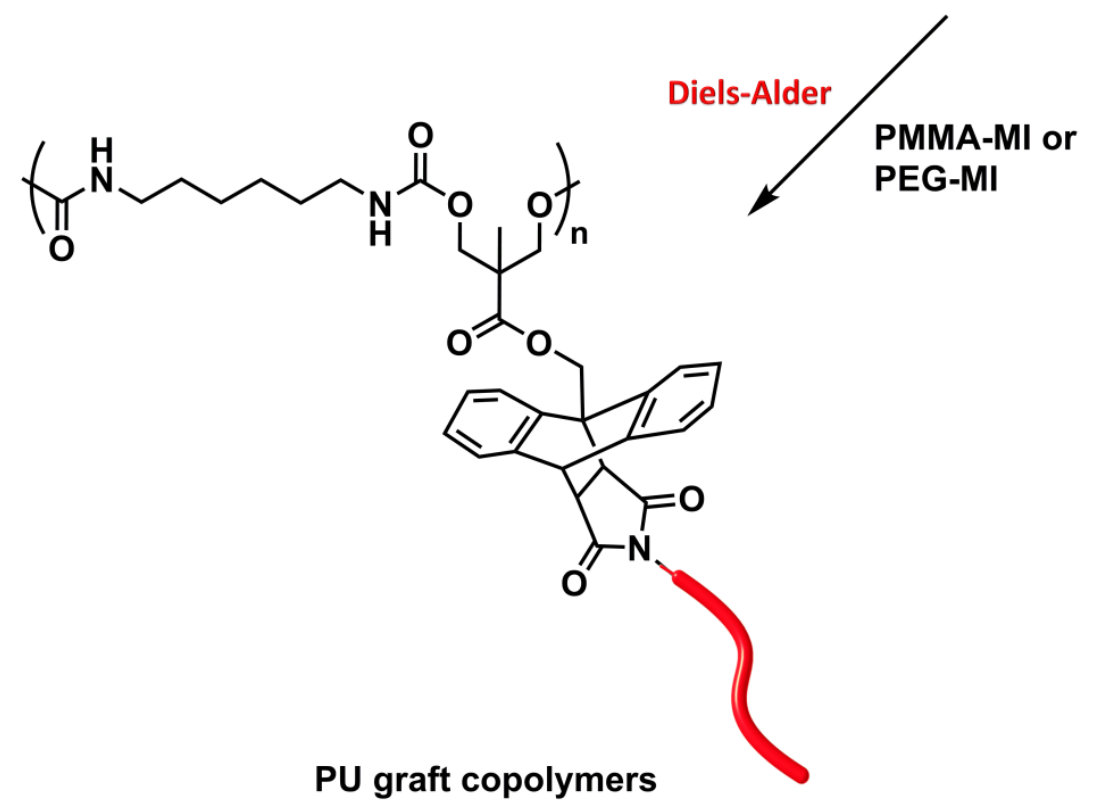

Figure 1.1: General pathway of synthesis and modification of aliphatic polyurethane with pendant anthracene moieties (PU-anthracene). 


\section{THEORETICAL PART}

\subsection{Condensation Polymerizations}

A large number of important and useful polymeric materials are not formed by chaingrowth processes involving reactive species such as radicals, but they proceed instead by conventional functional group transformations of polyfunctional reactants. These polymerizations often occur with the loss of a small byproduct (which even no loss of any byproduct in this thesis' synthesis of polyurethane), such as water, and generally (but not always) combine two different components in an alternating structure. The polyester Dacron and the polyamide Nylon 66, shown below, are two examples of synthetic condensation polymers, also known as step-growth polymers. In contrast to chain-growth polymers, most of which grow by carbon-carbon bond formation, step-growth polymers generally grow by carbon-heteroatom bond formation (C-O \& C-N in Dacron \& Nylon respectively). Although polymers of this kind might be considered to be alternating copolymers, the repeating monomeric unit is usually defined as a combined moiety [19].

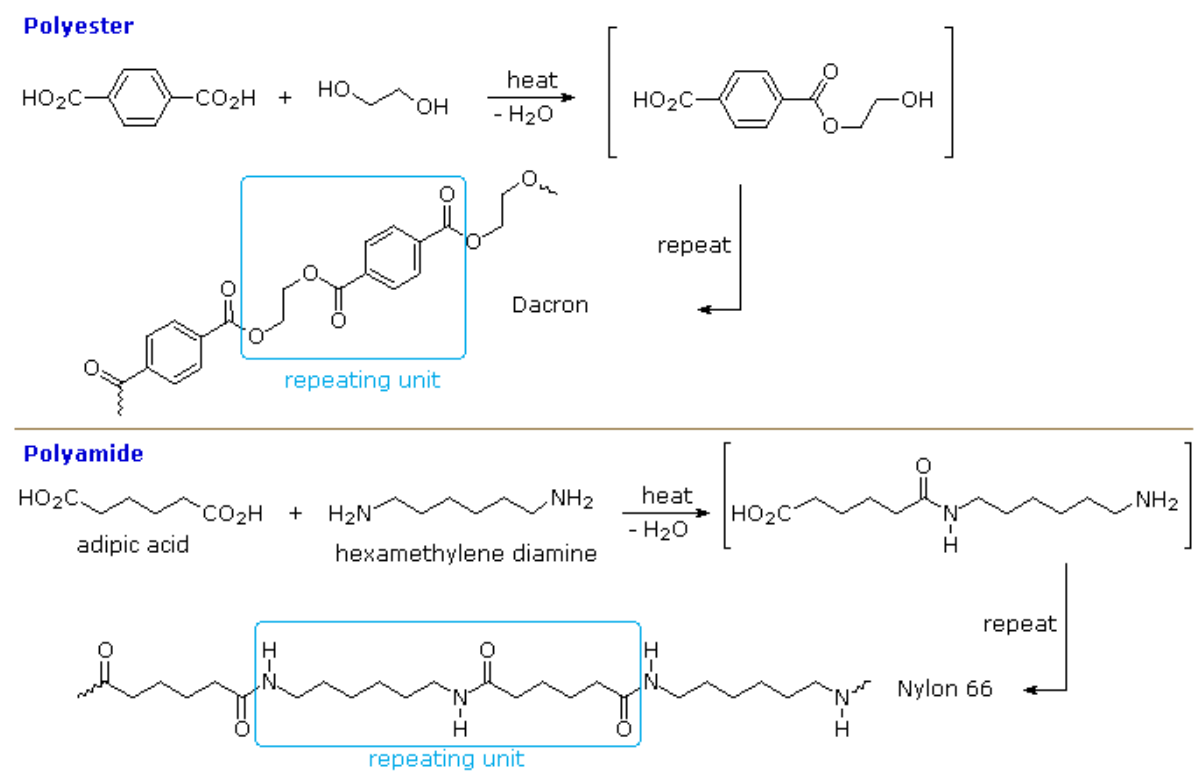

Figure 2.1: Two examples of synthetic condensation polymers. 
Examples of naturally occurring condensation polymers are cellulose, a polypeptide chain of proteins, and poly( $\beta$-hydroxybutyric acid), a polyester synthesized in large quantity by certain soil and water bacteria. Formulas for these are provided later on. Condensation polymers form slower than the addition polymers, often requiring heat, and they are generally lower in molecular weight. The terminal functional groups on a chain remain active, so that groups of shorter chains combine into longer chains in the late stages of polymerization. The presence of polar functional groups on the chains often enhances chain-chain attractions, particularly if these involve hydrogen bonding, and thereby, crystallinity and tensile strength. The following examples of condensation polymers are illustrative.

Note that for commercial synthesis the carboxylic acid components may actually be employed in the form of derivatives such as simple esters. Also, the polymerization reactions for Nylon 6 and Spandex do not proceed by elimination of water or other small molecules. Nevertheless, the polymer clearly forms by a step-growth process. 


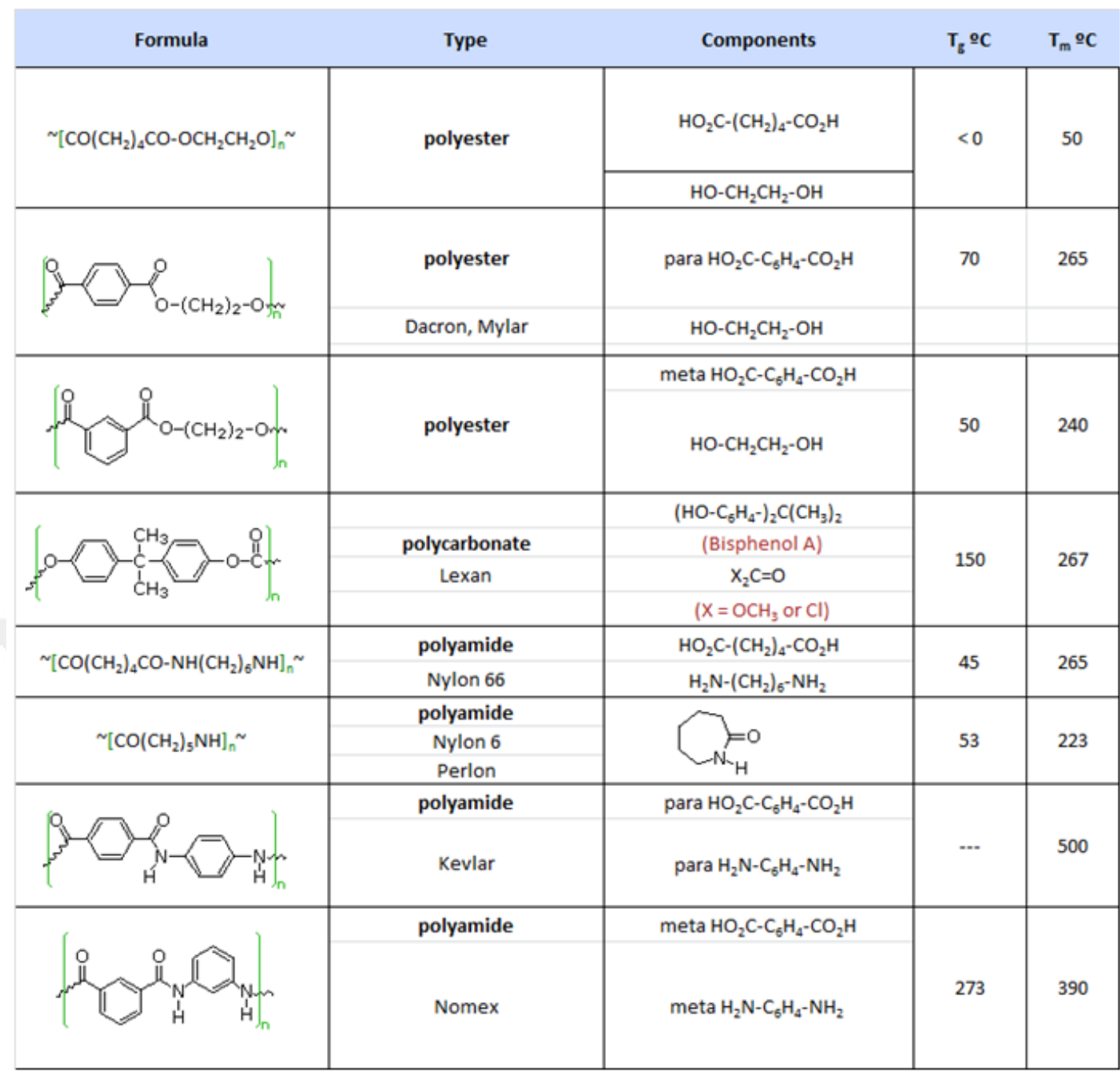

Figure 2.2: Some Condensation Polymers.

The difference in $\mathrm{Tg}$ and $\mathrm{Tm}$ between the first polyester (completely aliphatic) and the two nylon polyamides (5th \& 6th entries) shows the effect of intra-chain hydrogen bonding on crystallinity. The replacement of flexible alkylidene links with rigid benzene rings also stiffens the polymer chain, leading to increased crystalline character, as demonstrated for polyesters (entries 1, $2 \& 3$ ) and polyamides (entries 5, 6, $7 \& 8$ ). The high $\mathrm{T}_{\mathrm{g}}$ and $\mathrm{T}_{\mathrm{m}}$ values for the amorphous polymer Lexan are consistent with its brilliant transparency and glass-like rigidity. Kevlar and Nomex are extremely tough and resistant materials, which find use in bullet-proof vests and fire resistant clothing [19]. 
Interchain Hydrogen Bonding Enhances Crystallinity

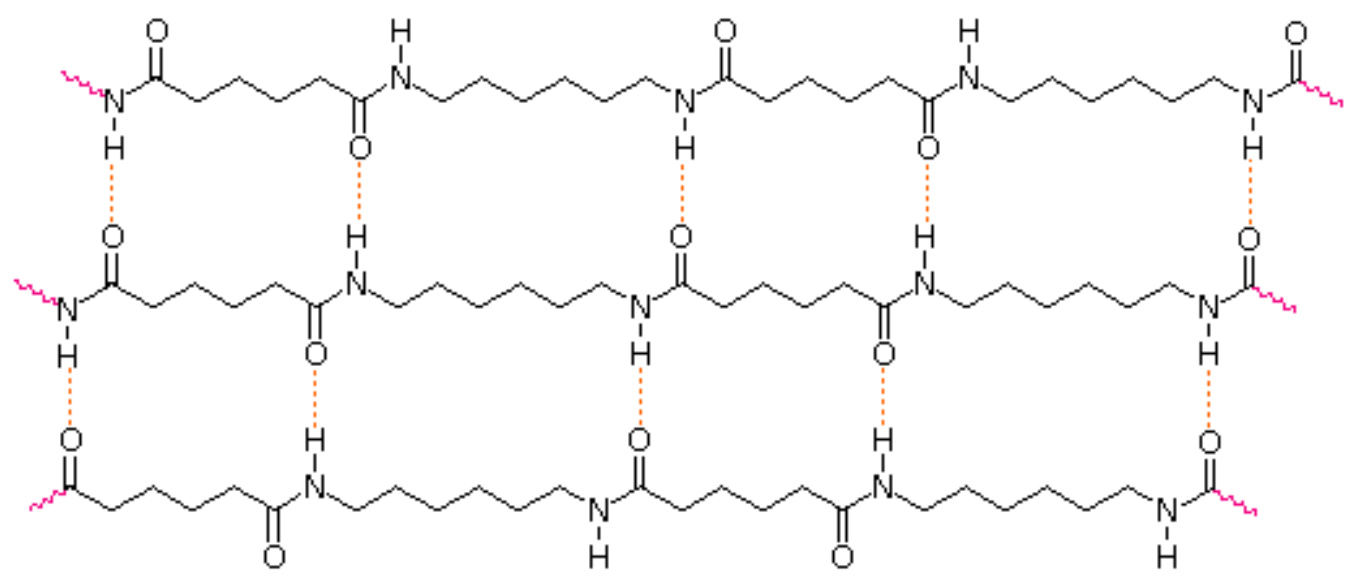

Figure 2.3: Enhancement of crystallinity by hydrogen bonding.

Many polymers, both addition and condensation, are used as fibers. The chief methods of spinning synthetic polymers into fibers are from melts or viscous solutions. Polyesters, polyamides, and polyolefins are usually spun from melts, provided the $\mathrm{Tm}$ is not too high. Polyacrylates suffer thermal degradation and are therefore spun from solution in a volatile solvent. Cold-drawing is an important physical treatment that improves the strength and appearance of these polymer fibers. At temperatures above $T_{g}$, a thicker than desired fiber can be forcibly stretched to many times its length; and in so doing the polymer chains become untangled, and tend to align in a parallel fashion. This cold-drawing procedure organizes randomly oriented crystalline domains, and also aligns amorphous domains so they become more crystalline. In these cases, the physically oriented morphology is stabilized and retained in the final product. This contrasts with elastomeric polymers, for which the stretched or aligned morphology is unstable relative to the amorphous random coil morphology. This cold-drawing treatment may also be used to treat polymer films (e.g. Mylar \& Saran) as well as fibers. 

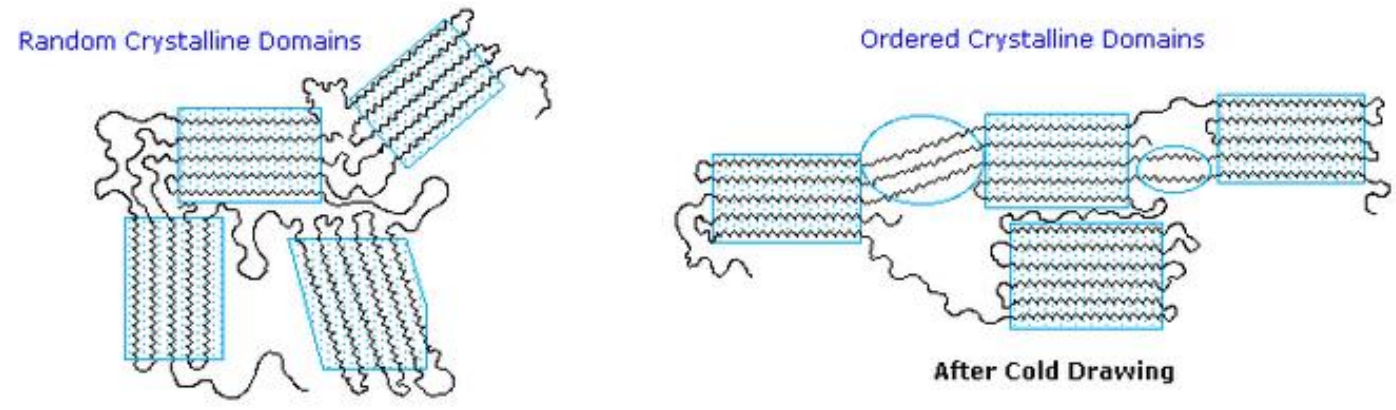

Figure 2.4: Types of crystalline domains.

Step-growth polymerization is also used for preparing a class of adhesives and amorphous solids called epoxy resins. Here the covalent bonding occurs by an SN2 reaction between a nucleophile, usually an amine, and a terminal epoxide. In the following example, the same bisphenol A intermediate used as a monomer for Lexan serves as a difunctional scaffold to which the epoxide rings are attached. Bisphenol A is prepared by the acid-catalyzed condensation of acetone with phenol [19].

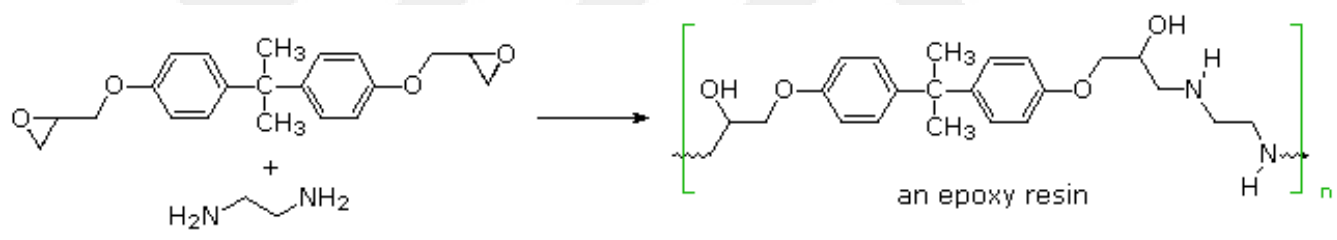

Figure 2.5: The structure of an epoxy resin.

\subsection{Controlled/“'Living” Polymerizations}

Conventional free radical polymerization (FRP) has many advantages over other polymerization processes. FRP does not require rigid conditions and can be used for the copolymerization of wide range of vinyl monomers [20]. The major limitation of FRP is poor control over some of the key elements of process that would allow the preparation of well-defined polymers with controlled molecular weight, polydispersity, composition, chain architecture, and site-specific functionality [21].

Living radical polymerizations started in the mid-1990s; radical polymerization was thought to be a mature process with relatively little left to discover. Chain polymerizations without chain-breaking reactions are called as living polymerization by Szwarc [1]. 
Well-defined polymers can only be synthesized by living ionic polymerizations or controlled/ "living" radical polymerization (C/LRP) methods [22]. Until recently, ionic polymerizations (anionic or cationic) were the only living techniques that efficiently controlled the structure and architecture of vinyl polymers. These polymerization techniques ensure low polydispersity materials, controlled molecular weight and defined chain ends but they are not useful for the polymerization and copolymerization of a wide range of functionalized vinylic monomers [23]. Furthermore, these techniques require stringent reaction conditions and pure reagents. To overcome all these limitations polymer chemists developed new concepts. These new concepts are often called controlled radical polymerization, living radical polymerization, control/“living” radical polymerization [24, 25]. Living or controlled/"living" polymerization techniques allow the synthesis of welldefined polymers with controlled molecular weight, polydispersities, and terminal functionalities. The polymerization proceeds until all of the monomer has been consumed, and further additions of monomer result in continued polymerization. Living or controlled/“living” polymerization can proceed by anionic, cationic, group transfer, metathesis, Ziegler-Natta or radical mechanisms [26].

Living polymerization provides end-group control and enables the synthesis of block copolymers by sequential monomer addition. Living polymerization would be demandable because of allowing the synthesis of block copolymers by sequential addition of different monomers. A reactive species $I^{*}$ initiates polymerization of monomer A (Figure 2.6).

$$
I^{*} \stackrel{A}{\longrightarrow} I-A_{n} * \stackrel{B}{\longrightarrow} I-A_{n}-B_{m} *
$$

Figure 2.6: Polymerization pathway.

When the polymerization of monomer $\mathrm{A}$ is complete, the reactive centers are intact owing to the absence of chain-breaking reactions. Addition of a second monomer B culminate in the formation of a block copolymer containing a long block of A repeat units followed by a long block of B repeat units.

Block copolymers have commercial potential for obtaining products that can include demandable properties of two or more homopolymers. Living radical polymerizations have good commercial potential for materials synthesis because many more monomers undergo radical polymerization [1]. However, it does not 
necessarily provide polymers with molecular weight (MW) control and narrow molecular weight distribution (MWD). To obtain well defined polymers the initiator should be consumed at early stages of polymerization and that the exchange between species of various reactivities should be at least as fast as propagation [27-29].

\subsubsection{Atom Transfer Radical Polymerization (ATRP)}

Atom transfer radical polymerization (ATRP) is a living radical polymerization process, which is consisting of the monomer, initiator, and catalyst composed of transition metal species with any suitable ligand. ATRP is a facile technique, which allows the preparation of well-defined polymers with narrow molecular weight distribution, predictable chain length, controlled microstructure, defined chain-ends and controlled architecture [30]. The ATRP system is consisting of the monomer, initiator, and catalyst composed of transition metal species with any suitable ligand. ATRP, which is the most versatile method of the controlled radical polymerization system, uses a wide variety of monomers, catalysts, solvents, and reaction temperature. ATRP is one of the most convenient methods to synthesize well-defined low molecular weight polymers [31].

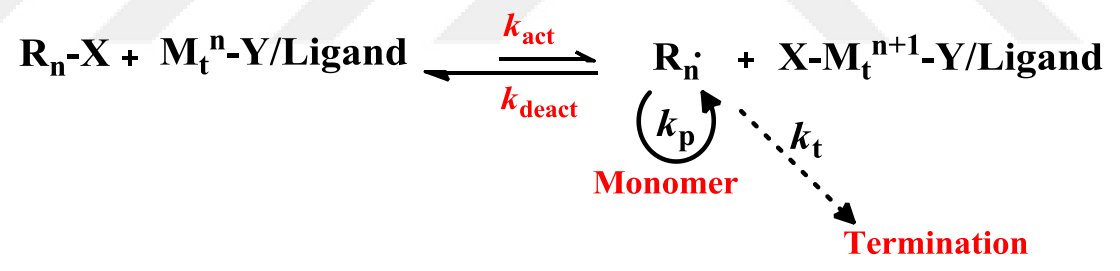

Figure 2.7: The mechanism of ATRP.

A general mechanism for ATRP shown in Fig. 2.7. The radicals the propagating species Rn•, are generated through a reversible redox process catalyzed by a transition metal complex. Radicals react reversibly with the oxidized metal halide complexes, $\mathrm{X}-\mathrm{Mtn}+1 /$ ligand, the deactivator, to reform the dormant species and the activator. These processes are fast, and the dynamic equilibrium that is established favors the dormant species. For that matter, all chains can begin growth at the same time, and the concentration of the free radicals is quite low, resulting in reduced amount of irreversible radical-radical termination. Since the deactivation rate constant is substantially higher than that of the activation reaction,

$$
k_{\text {eq }}=\frac{k_{\text {act }}}{k_{\text {deact }}} \sim 1^{-7}
$$


Each polymer chain is protected by spending most of the time in the dormant state, and thereby the permanent termination via radical coupling and disproportionation is substantially reduced [32]. ATRP will not occur at all, or occur very slowly, if the equilibrium constant is too small. On the contrary, too large an equlibrium constant will cause to a large amount of termination because of a high radical concentration [33]. Polymer chains grow by the addition of the free radicals to monomers in a manner similar to a conventional radical polymerization, with the rate constant of propagation, kp. Termination reactions (kt) also occur in ATRP, mainly through radical coupling and disproportionation. However, in a well-controlled ATRP, only several percents of the chains become dead via termination [32]. Polydispersities in ATRP decrease with conversion, with the rate constant of deactivation and also with the concentration of deactivator.

The molecular conversion and the amount of initiator used,

$$
D P=\frac{\Delta[M]}{[I]_{0}}
$$

polydispersities are low:

$$
\frac{M_{w}}{M_{n}}<1,3
$$

ATRP was grown by designing a suitable catalyst (transition metal compound and ligands), using an initiator with the suitable structure, and adjusting the polymerization conditions such that the molecular weights increased linearly with conversion and the polydispersities were typical of a living process [34, 35]. This allowed for an unprecendented control over the chain topology (stars, combs, branched), the composition (block, gradient, alternating, statistical), and the end functionality for a wide distribution of radically polymerizable monomers [36-38].

\subsubsection{Components of ATRP}

ATRP is a multicomponent system, which is comprises of the monomer, an initiator with transferable (pseudo)halogen.

\section{a) Monomers}

A variety of monomers have been used for atom transfer radical polymerization. The typical monomers are methacrylates, acrylonitriles, styrenes, acrylates and 
(meth)acrylamides in bulk, solution using organics or water as solvents, and emulsion, supercritical carbon dioxide, producing polymers with well-controlled molecular weights and structures [39].

Each monomer has its own intrinsic radical propagation rate. Therefore, for a specific monomer, the concentration of propagating radicals and rate of radical deactivation need to be adjusted to maintain polymerization control [33].

\section{b) Initiators}

In ATRP, alkyl halides are typically used as the initiator and the rate of the polymerization is first order with respect to the concentration of alkyl halides.

To obtain well-defined polymers with narrow molecular weight distributions, the halide group $\mathrm{X}$, must rapidly and selectively migrates between the growing chain and the transition-metal complex. Thus far, bromine and chlorine are the halogens that afford the best molecular weight control [40-43]. Iodine works well for acrylate polymerizations; however, in styrene polymerizations the heterolytic elimination of hydrogen iodide is too fast at high temperatures [44]. Fluorine is not used, because the $\mathrm{C}-\mathrm{F}$ bond is too strong to undergo homolytic cleavage [33].

It should be noted that R-X bonds can be cleaved not only homolytically, but also heterolytically, which depends mostly on the initiator structure and the choice of the transition metal catalyst.

The amount of the initiator in the ATRP determines the final molecular weight of the polymer at full monomeric conversion. The main role of the initiator is to determine the number of growing polymer chains. If initiation is fast and transfer and termination negligible, then the number of growing chains is constant and equal to the initial initiator concentration. The theoretical molecular weight or degree of polymerization (DP) increases reciprocally with the initial concentration of initiator in a living polymerization (Fig. 2.8).

$$
D P=\frac{\left[M_{0}\right]}{[\text { Initiator }]_{0}} \times \text { conversion }
$$

Simultaneously, polydispersities decrease with the conversion:

$$
\text { Polydispersity }=\left(\frac{M_{w}}{M_{n}}\right)
$$


The most frequently used initiator types used in the atom transfer radical polymerization systems are, 1-bromo-1-phenylethane (Styrene), 1-chloro-1phenylethane (Styrene), ethyl 2-bromopropionate (Methyl methacrylate), and ethyl 2- bromoisobutyrate (Methyl methacrylate). Two parameters are important for a successful ATRP initiating system; first, initiation should be fast in comparison with propagation. Second, the probability of side reactions should be minimized [45].

\section{c) Catalysts}

Catalyst is another important component of ATRP. Catalyst determines the position of the atom transfer equilibrium and the dynamics of exchange between the dormant and active species. There are several prerequisites for an efficient transition metal catalyst. First, the catalyst should react with initiator fast and quantitatively to ensure that all the polymer chains start to add monomer at the same time. Second, the catalyst must have moderate redox potential to ensure an appropriate equilibrium between dormant and active species. In general, a low redox potential of the catalyst leads to formation of the high $\mathrm{Cu}(\mathrm{II})$ concentration (equilibrium is shifted toward transient radicals). Consequently, a fast and uncontrolled polymerization is observed. In contrast, high redox potential strongly suppresses $\mathrm{Cu}$ (II) formation (equilibrium is shifted toward dormant species) via a halogen atom abstraction process leading to very slow polymerization. Third, the catalyst should be less sterically hindered, because large steric congestion around the metal center of catalyst results in a reduction of the catalyst activity. Fourth, a good catalyst should not afford side reactions such as Hoffman elimination, $\beta-\mathrm{H}$ abstraction, and oxidation/reduction of radicals [50].

A variety of transition metal complexes with various ligands have been studied as ATRP catalysts. The majority of work on ATRP has been conducted using copper as the transition metal. Apart from copper-based complexes, iron, nickel, rhenium, ruthenium, rhodium, and palladium have been used to some extent [51-56]. Recent work from Sawamoto and co-workers shows that the Ru-based complexes can compete with the $\mathrm{Cu}$-based systems on many fronts. A specific Fe-based catalyst has also been reported to polymerize vinyl acetate via an ATRP mechanism [46]. 


\section{d) Ligands}

The main role of the ligand in ATRP is to solubilize the transition-metal salt in the organic media and to adjust the redox potential and halogenophilicity of the metal center forming a complex with an appropriate reactivity and dynamics for the atom transfer. The ligand should complex strongly with the transition metal, should also allow expansion of the coordination sphere, and should allow selective atom transfer without promoting other reactions.

Nitrogen ligands have been used in copper- and iron-mediated ATRP. For coppermediated ATRP, nitrogen-based ligands work particularly well. In contrast, sulfur, oxygen, or phosphorus ligands are less effective due to in appropriate electronic effects or unfavorable binding constants.

For copper-based ATRP, the coordination chemistry of the transition-metal complex greatly affects the catalyst activity. The electronic ans steric effects of ligands are also important [33].

The most common ligands for ATRP systems are substituted bipyridines, alkyl pyridylmethanimines and multidentate aliphatic tertiary amines such as $\mathrm{N}, \mathrm{N}, \mathrm{N}^{\prime}, \mathrm{N}^{\prime \prime}, \mathrm{N}^{\prime \prime}-$ pentamethyldiethylenetriamine $\quad$ (PMDETA), and tris[2(dimethylamino)ethyl]amine ( $\mathrm{Me}_{6}$-TREN) $[58,59]$. In addition to those commercial products, it has been demonstrated that hexamethyltriethylene tetramine (HMTETA) provides better solubility of the copper complexes in organic media and entirely homogeneous reaction conditions [57]. Since copper complexes of this new ligand are almost insoluble in water, ATRP technique can be employed in preparing poly(acrylate esters) in aqueous suspensions [47].

In ATRP, also phosphorus-based ligands can be used to make complex most transition metals containing rhenium, ruthenium, iron, rhodium, nickel, and palladium, however not copper [33]. 

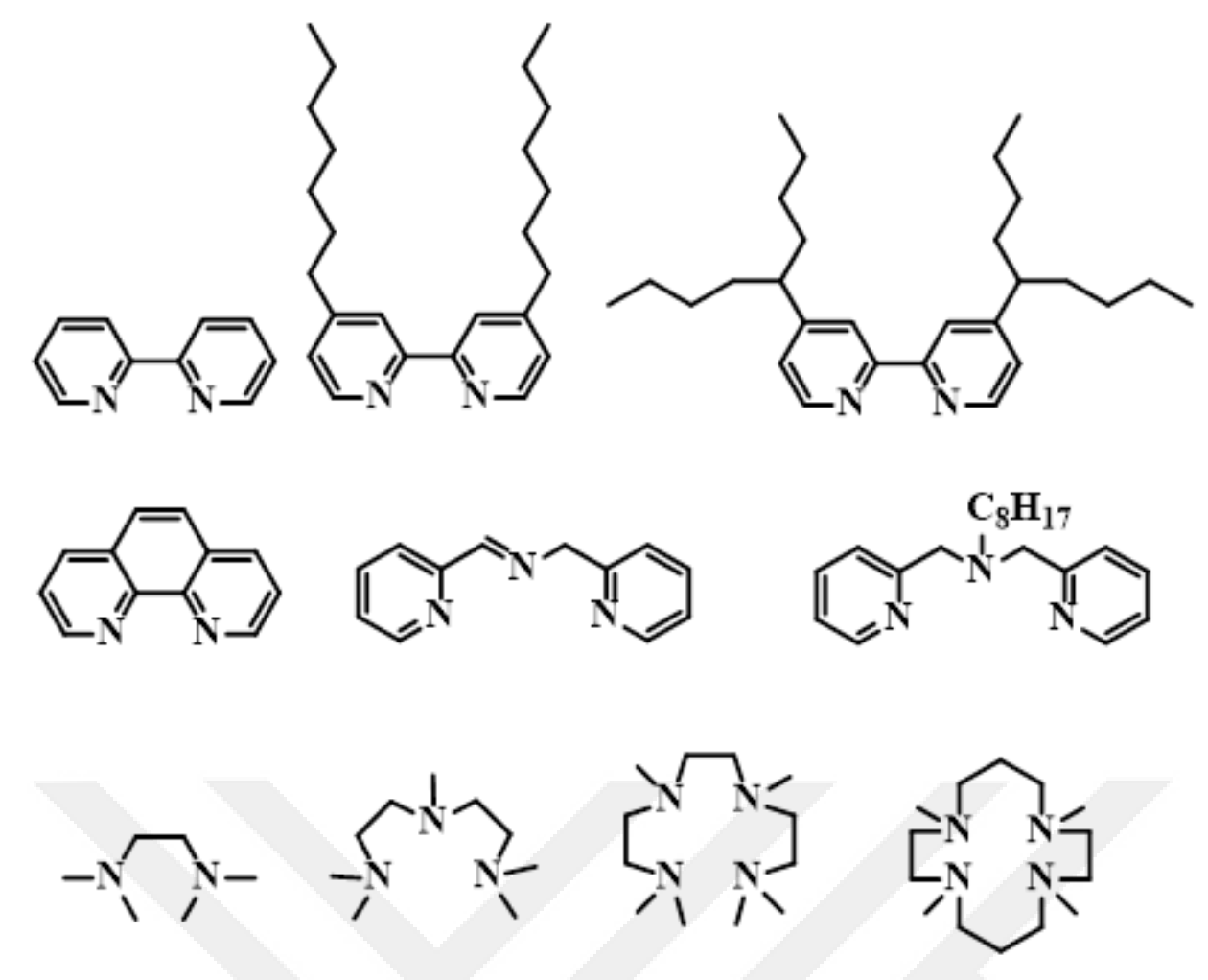

Figure 2.8: The most common ligands for ATRP systems.

\section{e) Solvents}

ATRP can be carried out either in bulk, in solution or in a heterogeneous system (e.g., emulsion, suspension). Various solvents such as benzene, toluene, anisole, diphenyl ether, ethyl acetate, acetone, $N, N$-dimethyl formamide (DMF), ethylene carbonate, alcohol, water, carbon dioxide and many others have been used for different monomers. A solvent is sometimes necessary especially when the obtained polymer is insoluble in its monomer [48].

\subsection{Graft Copolymers}

Graft copolymers belong to the general class of segmented copolymers and generally consist of a linear backbone of one composition and randomly distributed branches of a different composition. They have been prepared for many decades and have been used as impact resistant materials, thermoplastic elastomers, compatibilizers or emulsifiers for the preparation of stable blends or alloys. The number of potential applications has now expanded with the development of CRP.

Well-defined graft copolymers are most frequently prepared by either 2.3.1) a "grafting through" or 2.3.2) a "grafting from" controlled polymerization process. 
However the development of "click" chemistry [60] has led to a third approach, 2.3.3) based on site specific "grafting onto" chemistry.

\subsubsection{Grafting through}

The "grafting through" method (or macromonomer method) is one of the simplest ways to synthesize graft copolymers with well defined side chains.

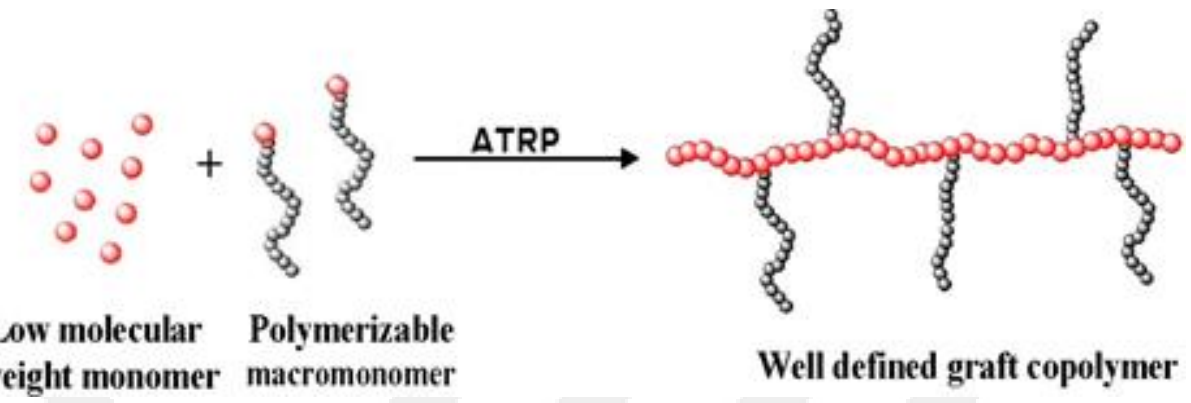

Figure 2.9: .The "grafting-through" mechanism.

Typically a low molecular weight monomer is radically copolymerized with a (meth)acrylate functionalized macromonomer. This method permits incorporation of macromonomers that have prepared by other controlled polymerization processes into a backbone prepared by a CRP. Macromonomers such as polyethylene [61, 62], poly(ethylene oxide) [63], polysiloxanes [64], poly(lactic acid) [65], polycaprolactone [66] have been incorporated into a polystyrene or poly(meth)acrylate backbone.

Moreover, it is possible to design well-defined graft copolymers by combining the CRP "grafting through" macromonomers procedure where the macromonomers had been prepared by any controlled polymerization process [67]. This combination of controlled polymerization processes allows control of polydispersity, functionality, copolymer composition, backbone length, branch length, and branch spacing by consideration of mole-ratio of the $\mathrm{MM}$ in the feed and reactivity ratio of both the monomer and macromonomer. Branches can be distributed homogeneously or heterogeneously based on the reactivity ratio of the terminal functional group on the macromonomer and the low molecular weight monomer; and, as shown in the properties section, this has a significant effect on the physical properties of the materials $[65,66]$. 


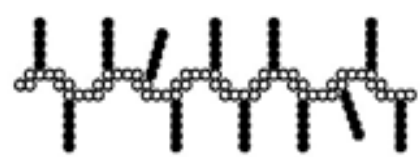

Homogeneous distribution of grafts

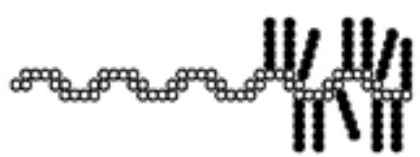

Heterogeneous distribution of grafts

Figure 2.10: Homogeneous or heteregeous distribution of grafts.

A series of segmented poly(alkyl methacrylate)-g-poly(D-lactide) / poly(dimethylsiloxane) terpolymers, with different topologies were prepared by employing a combination of the "grafting through" technique and CRP [68]. Two synthetic pathways were used. The first was a single-step approach in which a methacrylate monomer (methyl methacrylate or butyl methacrylate) was copolymerized with a mixture of a PLA macromonomer and a PDMS macromonomer. The second strategy was a two-step approach in which a graft copolymer containing one macromonomer was chain-extended by a copolymerization of the second macromonomer and the low-molecular weight methacrylate monomer. The molecular structure of the terpolymers was investigated by 2D GPC which indicated that well-defined terpolymers with controlled branch distribution were prepared via both pathways. The topologies of the graft terpolymers prepared by different combinations of the two step approach are displayed in the following schematic diagrams.

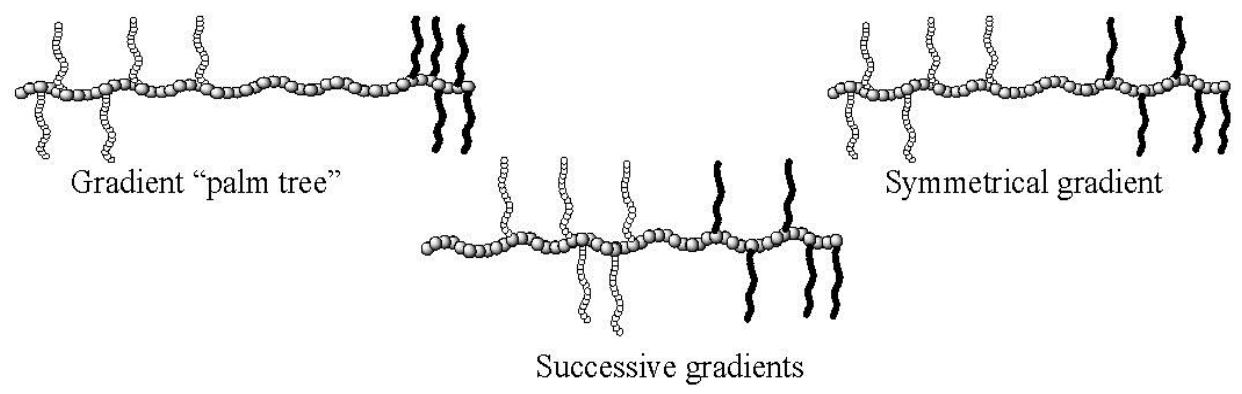

Figure 2.11: Types of gradients.

While properties have yet to be fully explored, it is likely that phase separation is modified by polymer topology and hence the properties of the material will differ even though compositions were held constant.

A spontaneous gradient graft copolymer was prepared by grafting through two different PEO macromonomers [69]. Selection of a PEO methacrylate with a methyl end-group (PEOMeMA, DP of the PEO = 23) and a PEO acrylate end-capped by a 
phenyl ring $(\mathrm{PEOPhA}, \mathrm{DP}$ of the $\mathrm{PEO}=4)$ for the copolymerization led to a spontaneous gradient of PEO grafts along the copolymer backbone. A gradient copolymer was formed because of the significant difference in the reactivity of the two PEO macromonomers. The resulting copolymer has a high fraction of PEOMeMA grafts at one end of the polymer chain, gradually changing through hetero-sequences to predominately $\mathrm{PEOPhA}$ at the other chain end. An increase in the initial feed ratio of PEO acrylate reduced the rate of change in the shape of the gradient.

\subsubsection{Grafting from}

The primary requirement for a successful "grafting from" reaction is a preformed macromolecule with distributed initiating functionality.

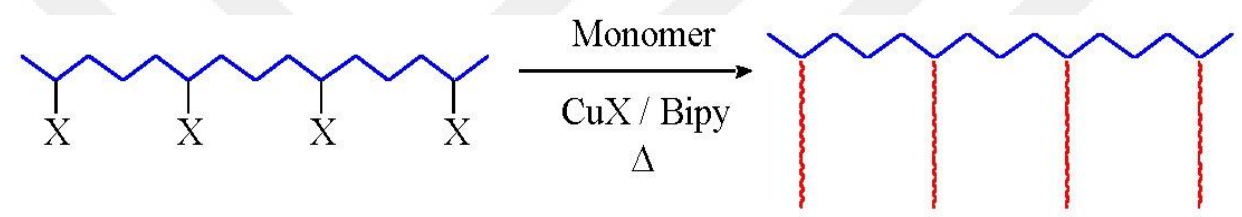

Figure 2.12: The "grafting from" technique.

Grafting from reactions have been conducted from polyethylene [70-72], polyvinylchloride $[73,74]$, and polyisobutylene $[75,76]$. The only requirement for a multifunctional ATRP grafting from macroinitiator is distributed radically transferable atoms along the polymer backbone. The initiating sites can be incorporated by copolymerization [70-73], be an inherent part of the first polymer [74], or incorporated in a post-polymerization reaction [75]. Indeed a prefunctionalized isobutylene rubber is commercially available from Exxon, (EXXPRO 3035) and has been employed in a grafting from ATRP of MMA forming a spectrum of materials ranging from elastomers to impact resistant poly(MMA) [75].

\subsubsection{Grafting onto}

Grafting onto has become a more efficient method for the preparation of graft copolymers with the rise of various "click" chemistries. This approach has been used for the preparation of well defined star molecules [77], loosely grafted copolymers, [78] and as noted in the following section densely grafted structures $[79,80]$. 


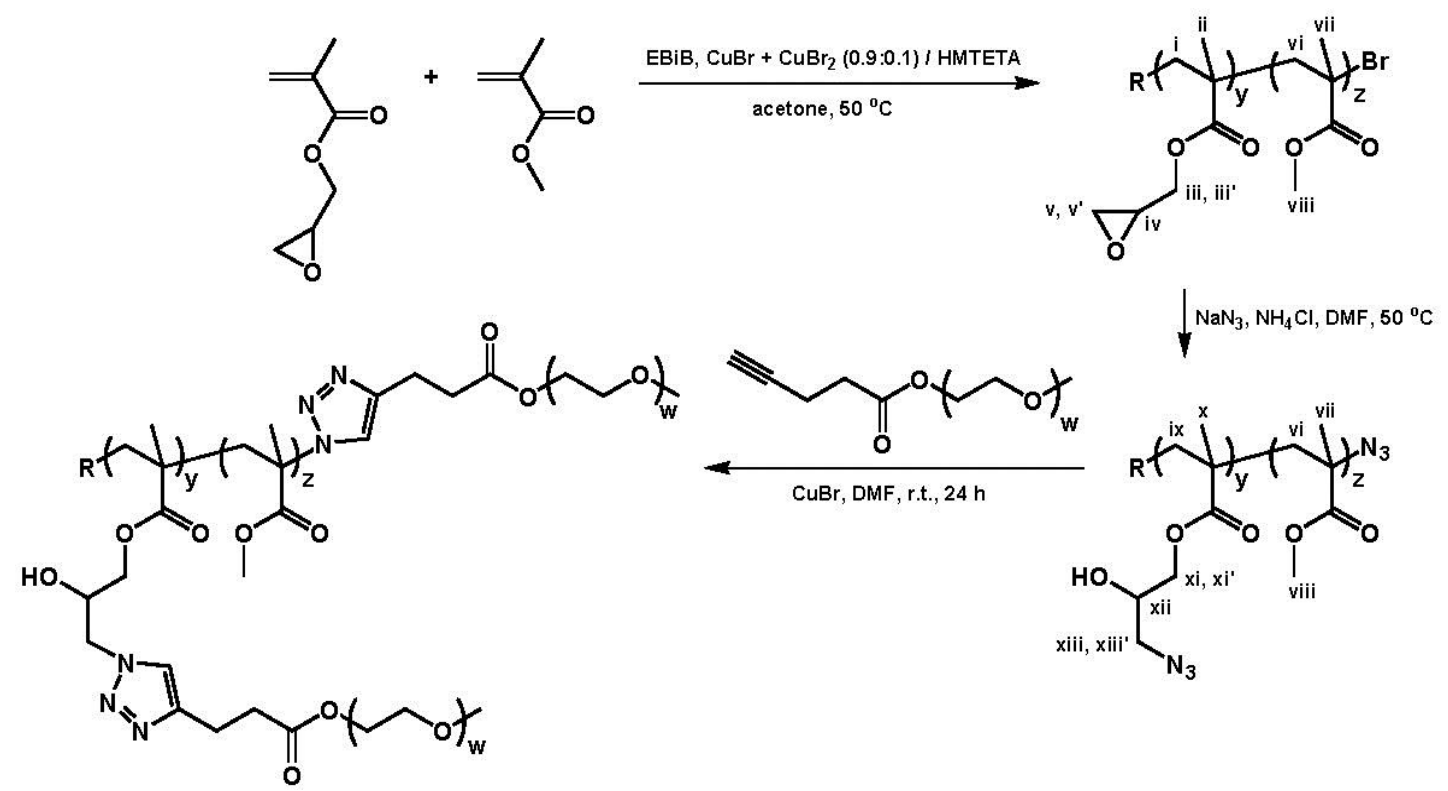

Figure 2.13: An example of "grafting onto".

A well-defined copolymers of glycidyl methacrylate $(<40 \mathrm{~mol} \%)$ and $\mathrm{Me}$ methacrylate prepared by ATRP. The glycidyl butyrate monomer unit that had been incorporated into the copolymer was efficiently opened with sodium azide in the presence of ammonium chloride in DMF at $50{ }^{\circ} \mathrm{C}$ to prepare a copolymer suitable for "grafting onto" using click linking chemistry. This click-type reaction led to the formation of a copolymer with distributed units of the corresponding 1-hydroxy-2azido functional group in high yields. These azide-cont aining copolymers were further functionalized in a second click reaction conducted at room temp. $\mathrm{CuBr} / \mathrm{N}, \mathrm{N}, \mathrm{N}$,N",N"-pentamethyldiethylenetriamine-catalyzed 1,3-dipolar cycloaddition of poly(ethylene oxide) methyl ether pentynoate yielded loosely grafted polymeric brushes with hydrophilic PEO side chains.

Another "high yield" chemical reaction, familiar to all interested in CRP, was exploited in a simple one-pot synthesis of heterograft copolymers via "grafting onto" by atom transfer nitroxide radical coupling chemistry [81]. The main chain was prepared by anionic ring-opening copolymerization of ethylene oxide (EO) and 4glycidyloxy-2,2,6,6-tetramethylpiperidine-1-oxyl (GTEMPO) then polystyrene and poly(tert-Bu acrylate) with bromine end (PS-Br, PtBA-Br) were prepared by ATRP. When the three polymers were mixed in the presence of $\mathrm{CuBr} / \mathrm{N}, \mathrm{N}, \mathrm{N}^{\prime}, \mathrm{N}^{\prime \prime}, \mathrm{N}^{\prime \prime}-$ pentamethyldiethylenetriamine (PMDETA) at $90{ }^{\circ} \mathrm{C}$, the formed secondary carbon radicals at the PS and PtBA chain ends were quickly trapped by nitroxide radicals on 
poly(GTEMPO-co-EO). It was found that the density of GTEMPO groups on the main chain of the poly(GTEMPO-co-EO), the MW of PS/PtBA side chains, and the structure of macroradicals significantly affected the efficiency of the grafting onto reaction.

Heterograft copolymers poly(4-glycidyloxy-2,2,6,6-tetramethylpiperidine-1-oxyl-coethylene oxide)-graft-polystyrene and poly(tert-Bu acrylate) (poly(GTEMPO-coEO)-g-PS/PtBA) were synthesized in one-pot by atom transfer nitroxide radical coupling (ATNRC) reaction via "graft onto."

\subsection{Click Chemistry}

In 2001, Sharpless and coworkers introduced "click" chemistry, a new approach in organic synthesis that involves a handful of almost perfect chemical reactions [82]. Click chemistry can be summarized to only one sentence: "Molecules that are easy to make". Requirements for click reactions involving one or more polymeric reagents, which orginally defined by Sharpless, are high yields, stable compounds, modular, wide in scope, chemoselective, single reaction trajectory. There are other adapted requirements, which are related to synthetic polymer chemistry, like equimolarity, large-scale purification, fast timescale [83].

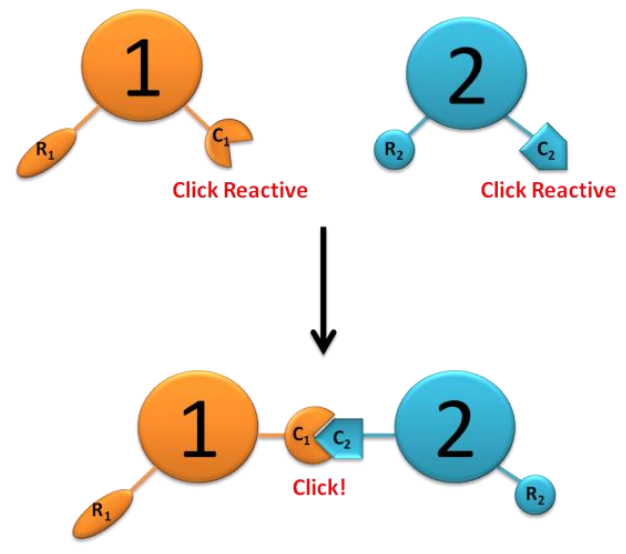

Figure 2.14: A general notation of click chemistry.

Nowadays there are several processes have been identified under this term in order to meet these criterias such as nucleophilic ring opening reactions; non-aldol carbonyl chemistry; thiol additions to carbon-carbon multiple bonds (thiol-ene and thiol-yne); and cycloaddition reactions. 
Among these selected reactions, copper(I)-catalyzed azide-alkyne (CuAAC) and Diels-Alder (DA) cycloaddition reactions and thiol-ene reactions have gained much interest among the chemists not only the synthetic ones but also the polymer chemists.

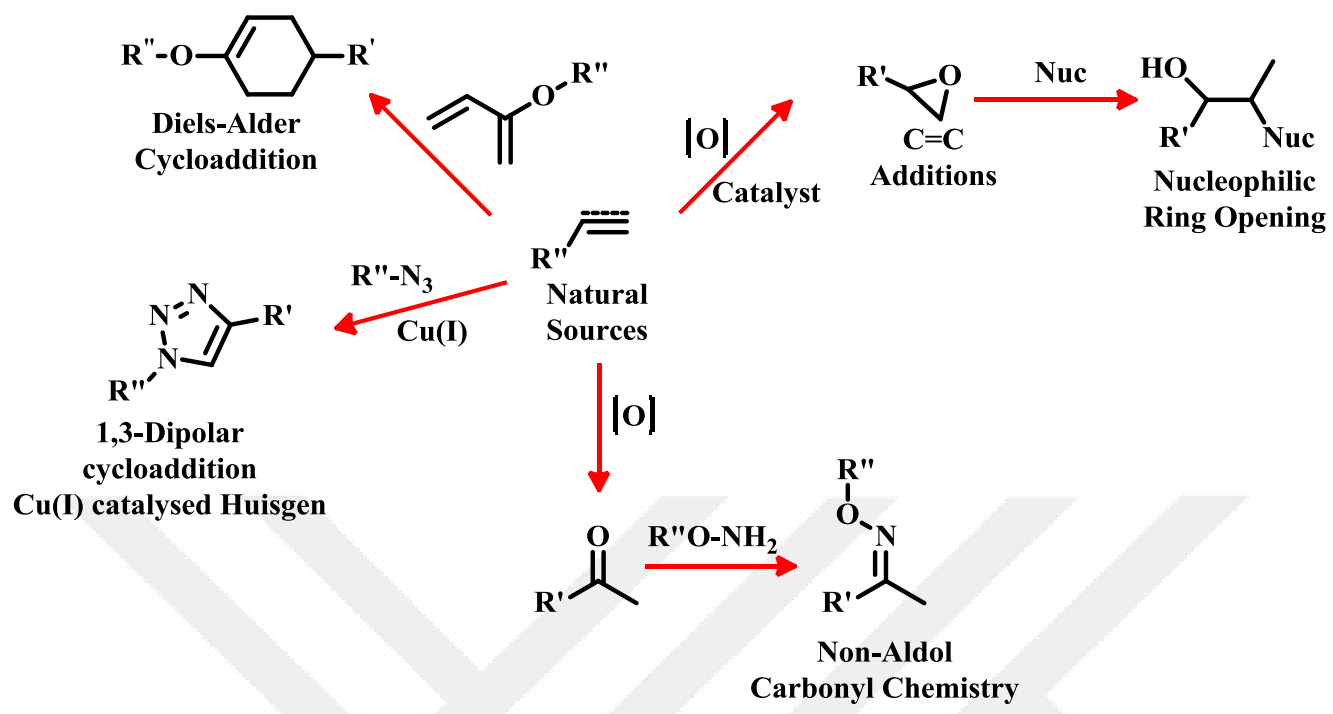

Figure 2.15: A selection of reactions which match the criteria of Click Chemistry.

During the last years, "click" cycloadditions became also very popular in polymer chemistry, as a tool for functionalizing synthetic macromolecules [30].

\subsubsection{Diels-Alder Reaction}

Diels-Alder (DA) reaction is one of the most common reactions used in organic chemistryand invented by Otto Diels and Kurt Alder who recieved the Nobel Prize in 1950 for their discovery [84]. The Diels-Alder reaction is a concerted $[4 \pi+2 \pi]$ cycloaddition reaction of a conjugated diene and a dienophile to yield a 6-membered ring. This reaction is one of the most powerful tools used in the synthesis of important organic molecules. The three double bonds in the two starting materials are converted into two new single bonds and one new double bond to afford cyclohexenes and related compounds (Fig. 2.18).

This reaction is named for Otto Diels and Kurt Alder, who received the 1950 Nobel prize for discovering this useful transformation [85-87]. 


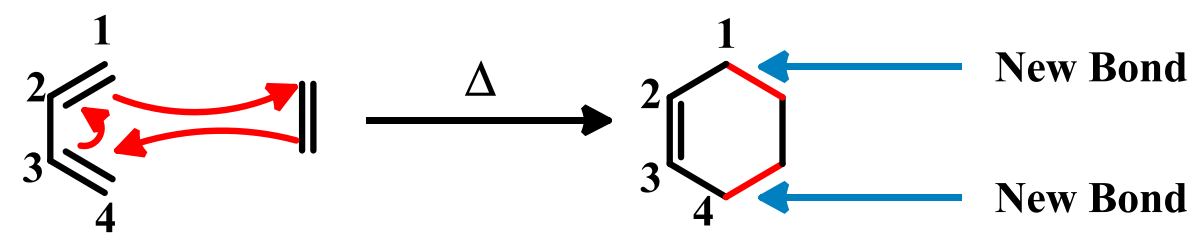

\section{Diene Dienophile}

Figure 2.16: The mechanism of Diels-Alder reaction.

DA cycloaddition reaction forms not only carbon-carbon bonds but also heteroatomheteroatom bonds (hetero-Diels-Alder, HDA) and it is widely used synthetically to prepare six-membered rings [88]. Typically, the DA reaction works best when either the diene is substituted with electron donating groups (like -OR, -NR2, etc) or when the dienophile is substituted with electron-withdrawing groups (like -NO2, - $\mathrm{CN}$, COR, etc) [89].

Some attractive features of DA reactions (retro-Diels-Alder, rDA) are thermal reversibility and decomposition reaction of the cyclic system that can be controlled by temperature [90].

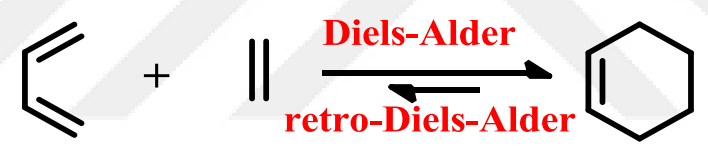

Figure 2.17: General mechanism of Diels-Alder/retro Diels-Alder reactions of dienophile and dien.

These DA reactions are suitable for green chemistry because of the absance of metal catalyst in reaction medium. DA "click" reactions can be combined with the living /controlled polymerization methods such as RAFT, NMRP, ATRP and ROP. By using simple and efficient DA cycloaddition reactions, linear thermoplastic, thermosetting polymers and telechelic polymers can be synthesized.

In brief, DA "click" reactions show great potential for the prepration of tailor-made functional materials such as telechelic polymers, block, graft, star, star-block, Hshaped polymers, dendirimers, bioconjugates and hybris materials. DA "click" chemistry has some advantages such as water-solubility, high reaction yields, no detectable side-reactions and no requirement for additional catalysts [91]. 


\subsubsection{Stereochemistry of Diels-Alder Reaction}

There are stereochemical and electronic requirements for the DA reaction to occur smoothly. First, the diene must be in an s-cis conformation instead of an s-trans conformation to allow maximum overlap of the orbitals participating in the reaction (Fig. 2.20).

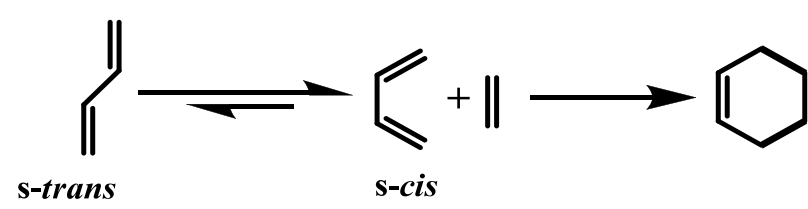

Figure 2.18: Diels-Alder reaction's cis- and trans conformations.

The "s" in s-cis and s-trans refers to "sigma", and these labels describe the arrangement of the double bonds around the central sigma bond of a diene. Dienes often exist primarily in the lower energy s-trans conformation, but the two conformations are in equilibrium with each other. The s-cis conformation is able to react in the DA reaction and the equilibrium position shifts towards the s-cis conformer to replenish it. Over time, all the s-trans conformer is converted to the scis conformer as the reaction proceeds.

A unique type of stereoselectivity is observed in DA reactions when the diene is cyclic. In the reaction of maleic anhydride with cyclopentadiene, for example, the endo isomer is formed (the substituents from the dienophile point to the larger bridge) rather than the exo isomer (the substituents from the dienophile point away from the larger bridge) (Fig. 2.21).

The preference for endo-stereochemistry is "observed" in most DA reactions. The fact that the more hindered endo product is formed puzzled scientists until Woodward, Hoffmann, and Fukui used molecular orbital theory to explain that overlap of the $p$ orbitals on the substituents on the dienophile with p orbitals on the diene is favorable, helping to bring the two molecules together [92, 93]. 

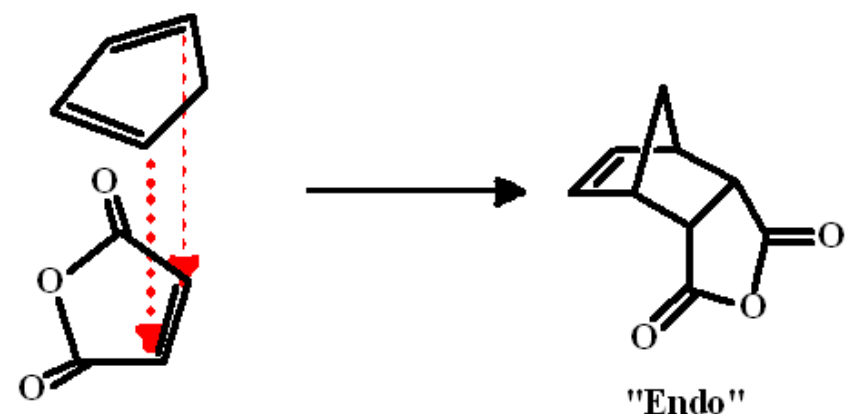

"Endo"

substituents
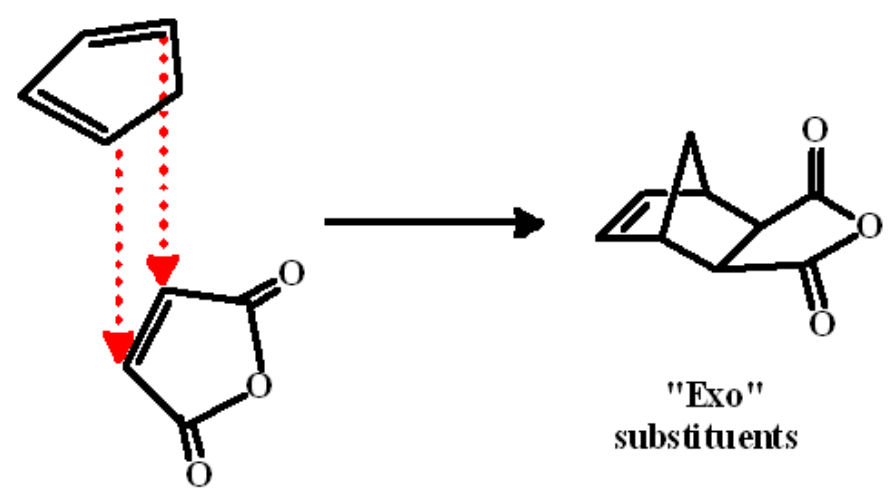

"Exo"

substituents

Figure 2.19: Endo and exo conformations.

Hoffmann and Fukui shared the 1981 Nobel Prize in chemistry for their molecular orbital explanation of this and other organic reactions. In the illustration below, notice the favorable overlap (matching light or dark lobes) of the diene and the substituent on the dienophile in the formation of the endo product (Fig. 2.22):

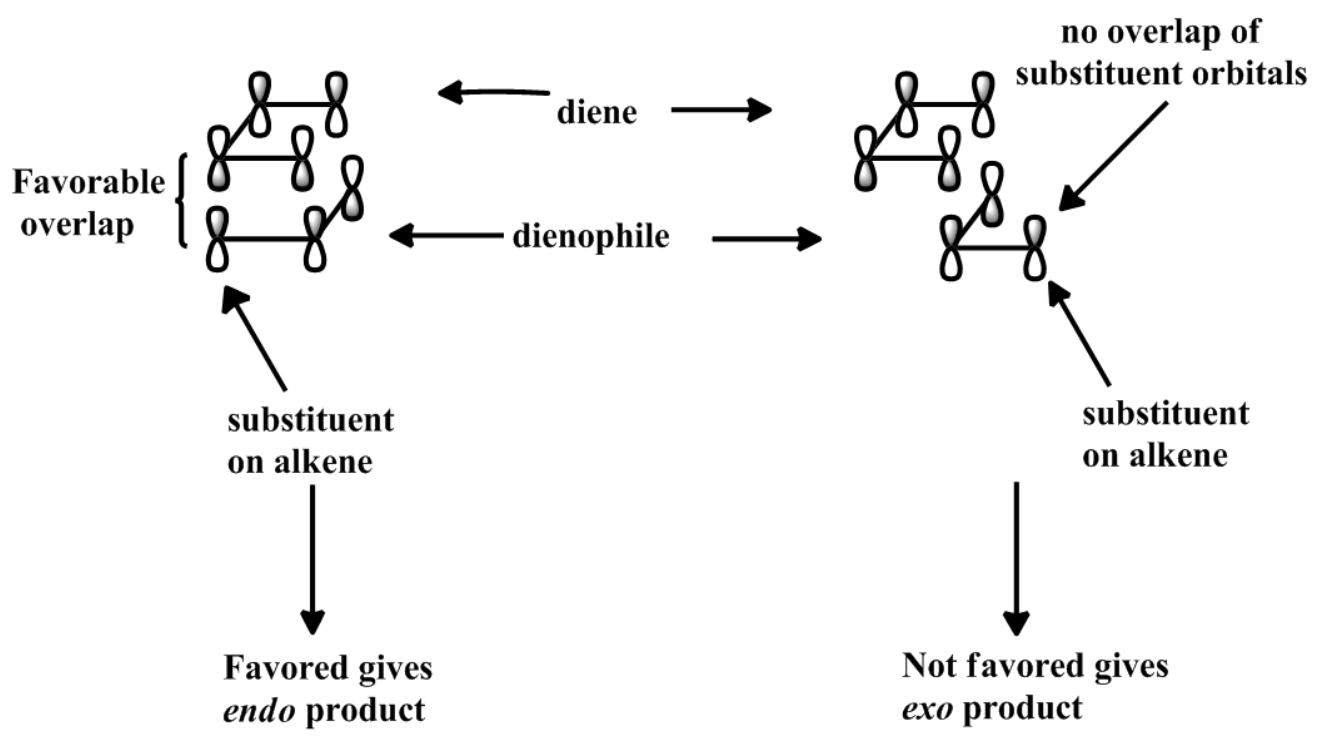

Figure 2.20: Pi overlaps of endo - exo conformations. 
Often, even though the endo product is formed initially, an exo isomer will be isolated from a DA reaction. This occurs because the exo isomer, having less steric strain than the endo, is more stable, and because the DA reaction is often reversible under the reaction conditions. In a reversible reaction, the product is formed, reverts to starting material, and forms again many times before being isolated.

The more stable the product, the less likely it will be to revert to the starting material. If the reaction is not reversible under the conditions used, the kinetic product will be isolated. However, if the first formed product is not the most stable product and the reaction is reversible under the conditions used, then the most stable product, called the thermodynamic product, will often be isolated. 


\section{EXPERIMENTAL WORK}

\subsection{Materials}

Methyl methacrylate (MMA, 99\%, Aldrich) was passed through basic alumina column to remove inhibitor and then distilled over $\mathrm{CaH} 2$ in vacuum prior to use. Poly(ethylene glycol monomethyl ether) (PEG-OH) $(\mathrm{Mn}=550 \mathrm{~g} / \mathrm{mol}$, Acros) was dried over anhydrous toluene by azeotropic distillation. N,N,N',N',N',pentamethyldiethylenetriamine (PMDETA, 99\%, Aldrich) was distilled over $\mathrm{NaOH}$ before use. Hexamethylenediisocyanate (HMDI, 98\%, Aldrich), dibutyltindilaurate (DBTL, 95\%, Aldrich), N,N'-dicyclohexylcarbodiimide (DCC, 99\%, Aldrich), 4dimethylaminopyridine (DMAP, 99\%, Acros), $\mathrm{CuCl}$ (99.9\%, Aldrich), 9-anthracene methanol (97\%, Aldrich) were used as received. $\mathrm{CH} 2 \mathrm{Cl} 2$ (99.9\%, Aldrich) was used after distillation over P2O5. Tetrahydrofuran (THF, 99.8\%, J.T. Baker) was dried and distilled over benzophenone-metallic sodium. Solvents unless specified here were purified by conventional procedures. All other reagents were purchased from Aldrich and used as received without further purification.

\subsection{Instrumentation}

1H NMR spectra were recorded on an Agilent VNMRS 500 (500 MHz for proton and $125 \mathrm{MHz}$ for carbon). The conventional gel permeation chromatography (GPC) measurements were carried out with an Agilent instrument (Model 1100) consisting of a pump, refractive index (RI), and ultraviolet (UV) detectors and four Waters Styragel columns (guard, HR 5E, HR 4E, HR 3, and HR 2), (4.6 mm internal diameter, $300 \mathrm{~mm}$ length, packed with $5 \mu \mathrm{m}$ particles). The effective molecular weight ranges are 2000-4,000,000, 50-100,000, 500-30,000, and 500-20,000, respectively. THF and toluene were used as eluent at a flow rate of $0.3 \mathrm{~mL} / \mathrm{min}$ at 30 ${ }^{\circ} \mathrm{C}$ and as an internal standard, respectively. The apparent molecular weights (Mn,GPC and Mw,GPC) and polydispersities (Mw/Mn) were determined with a calibration based on linear PS standards using PL Caliber Software from Polymer Laboratories. The differential scanning calorimetry (DSC) measurements were 
performed on a DSC Q1000 (TA Instruments) with a heating rate of $10 \mathrm{oC} / \mathrm{min}$ under nitrogen. All data were collected from a second heating cycle, and the glass transition $(\mathrm{Tg})$ temperatures were determined as a midpoint of thermograms. Thermo gravimetric analysis (TGA) measurements were carried out by using TGA Q50 (TA instruments) at a heating rate of $10{ }^{\circ} \mathrm{C} / \mathrm{min}$ under nitrogen atmosphere. UV measurements were recorded using VWR UV-1600 PC spectrophotometer in $\mathrm{CH} 2 \mathrm{Cl} 2$. The Diels-Alder reaction efficiency was monitored by following the disappearance of a characteristic signal at $367 \mathrm{~nm}$.

\subsection{Synthetic Procedure}

Anthracen-9-yl methyl 3-hydroxy-2-(hydroxymethyl)-2-methylpropanoate (anthracene diol), 1,13 4-(2-hydroxyethyl)-10-oxa-4-azatricyclo[5.2.1.02,6]dec-8ene-3,5-dione 2,14 $\alpha$-furan protected-maleimide terminated-PEG (PEG-MI)15 $(\mathrm{Mn}, \mathrm{theo}=840 \mathrm{~g} / \mathrm{mol}, \mathrm{Mn}, \mathrm{NMR}=860 \mathrm{~g} / \mathrm{mol}, \mathrm{Mn}, \mathrm{GPC}=550 \mathrm{~g} / \mathrm{mol}, \mathrm{Mw} / \mathrm{Mn}=1.09$, relative to PS standards) and $\alpha$-furan protected-maleimide terminated-PMMA $($ PMMA-MI) $15(\mathrm{Mn}$, theo $=1700 \mathrm{~g} / \mathrm{mol}, \mathrm{Mn}, \mathrm{NMR}=2100 \mathrm{~g} / \mathrm{mol}, \mathrm{Mn}, \mathrm{GPC}=2500$ $\mathrm{g} / \mathrm{mol}, \mathrm{Mw} / \mathrm{Mn}=1.33$, relative to PMMA standards) were prepared according to the published procedures.

\subsubsection{Synthesis of 2,2,5-trimethyl-[1,3]dioxane-5-carboxylic acid}

The 2,2-bis(hydroxymethyl)propanoic acid (16 g, $119.2 \mathrm{mmol}$ ) along with p-TSA (0.9 g, $4.64 \mathrm{mmol})$, and 2,2-dimethoxypropane (22.4 mL, $178.8 \mathrm{mmol})$ dissolved in $80 \mathrm{~mL}$ of dry acetone, and stirred $2 \mathrm{~h}$ at room temperature. In the vicinity of $2 \mathrm{~h}$, while stirring continued the reaction mixture was neutralized with $12 \mathrm{~mL}$ of totally $\mathrm{NH} 4 \mathrm{OH}(25 \%)$, and absolute ethanol (1:5), filtered off by-products and subsequent dilution with dichloromethane $(240 \mathrm{~mL})$, and once extracted with distilled water (80 $\mathrm{mL})$. The organic phase dried with $\mathrm{Na} 2 \mathrm{SO} 4$, concantrated to yield $14.8 \mathrm{~g}(71 \%)$ as white solid after evaporation of the solvent. 1H NMR (CDCl3, $\delta) 4.18(\mathrm{~d}, 2 \mathrm{H}$, $\mathrm{CCH} 2 \mathrm{O}$ ), 3.63 (d, 2H, CCH2O), 1.38 (s, 3H, CCH3) 1.36 (s, 3H, CCH3), 1.18 (s, $3 \mathrm{H}, \mathrm{C}=\mathrm{OC}(\mathrm{CH} 2 \mathrm{O}) 2 \mathrm{CH} 3)$. 


\subsubsection{Synthesis of anthracen-9-ylmethyl 2,2,5-trimethyl-[1,3]dioxane-5- carboxylate}

9-Anthracene methanol(6.5 g, $31.25 \mathrm{mmol})$ was dissolved in $100 \mathrm{~mL}$ of $\mathrm{CH} 2 \mathrm{Cl} 2$ and $5(6.5 \mathrm{~g}, 37.4 \mathrm{mmol})$, and DMAP $(5.5 \mathrm{~g}, 45.13 \mathrm{mmol})$ were added to the reaction mixture in that order. After stirring 5 minutes at room temperature, DCC $(9.25 \mathrm{~g}$, $44.9 \mathrm{mmol}$ ) dissolved in $50 \mathrm{~mL}$ of $\mathrm{CH} 2 \mathrm{Cl} 2$ was added. Reaction mixture was stirred overnight at room temperature and urea byproduct was filtered. Solvent was evaporated and the remaining product was purified by column chromatography over silica gel eluting with hexane/dichlorometane (4:1) to give pale yellow oil (Yield = $9.22 \mathrm{~g} ; 81 \%)$. 1H NMR (CDCl3, $\delta) 8.50$ (s, 1H, ArH of anthracene), 8.32 (d, 2H, ArH of anthracene), 8.02 (d, 2H, ArH of anthracene), 7.60-7.45 (m, 4H, ArH of anthracene), 6.2 (s, 2H, CH2-anthracene), 4.14 (d, 2H, CCH2O), $3.58(\mathrm{~d}, 2 \mathrm{H}$, $\mathrm{CCH} 2 \mathrm{O}), 1.38$ (s, 3H, $\mathrm{CCH} 3), 1.35$ (s, 3H, $\mathrm{CCH} 3), 1.08$ (s, 3H, $\mathrm{C}=\mathrm{OC}(\mathrm{CH} 2 \mathrm{O}) 2 \mathrm{CH} 3)$.

\subsubsection{Synthesis of anthracen-9-yl methyl 3-hydroxy-2-(hydroxymethyl)-2-}

\section{methylpropanoate}

9-anthrylmethyl 2,2,5-trimethyl-1,3-dioxane-5-carboxylate (9.22 g, $25.3 \mathrm{mmol})$ was dissolved in a mixture of $100 \mathrm{~mL}$ of $\mathrm{THF}$ and $100 \mathrm{~mL}$ of $1 \mathrm{M} \mathrm{HCl}$. The reaction mixture was stirred for $2 \mathrm{~h}$ at room temperature. The precipitated product was filtered off and reaction mixture was concentrated and extracted with $480 \mathrm{~mL}$ of $\mathrm{CH} 2 \mathrm{Cl} 2$ and $80 \mathrm{~mL}$ of water. The combined organic phase was dried with $\mathrm{Na} 2 \mathrm{SO} 4$ and concentrated. Hexane was added to the reaction mixture and it was kept in deep freeze overnight to give white solid (Yield $=8.2 \mathrm{~g}, 89 \%)$. 1H NMR $(\mathrm{CDCl} 3, \delta) 8.52$ (s, 1H, ArH of anthracene), $8.30(\mathrm{~d}, 2 \mathrm{H}, \mathrm{ArH}$ of anthracene), $8.03(\mathrm{~d}, 2 \mathrm{H}, \operatorname{ArH}$ of anthracene), 7.60-7.45 (m, 4H, ArH of anthracene), 6.2 (s, 2H, CH2-anthracene), 3.85 (d, 2H, CH2OH), 3.66 (d, 2H, CH2OH), 2.17(br, 2H, OH), 1.01 (s, 3H, CCH3).

\subsubsection{Synthesis of pendant anthracene-functional polyurethane (PU- anthracene) via condensation polymerization}

1, anthracen-9-ylmethyl 3-hydroxy-2-(hydroxymethyl)-2-methylpropanoate ( anthracene diol $0.500 \mathrm{~g}, 1.54 \mathrm{mmol}, 1.0$ equiv), HMDI (0.247 mL, $1.54 \mathrm{mmol} 1.0$ equiv) and DBTL (0.045 mL, 0.077 mmol, 0.05 equiv) were dissolved in $\mathrm{CH} 2 \mathrm{Cl} 2$ (5 $\mathrm{mL}$ ). Subsequently, the solution was bubbled with nitrogen for $30 \mathrm{~min}$ and stirred at 
room temperature for 10 days. After that time the polymer solution was precipitated in $50 \mathrm{~mL}$ of methanol and the solvent was removed by decantation. The residual solid was dissolved in THF and consequently precipitated in methanol. The purified polymer was finally dried at $40{ }^{\circ} \mathrm{C}$ in a vacuum oven for $24 \mathrm{~h}$ (Yield $=0.65 \mathrm{~g}, 86 \%$, $\mathrm{Mn}, \mathrm{GPC}=12900 \mathrm{~g} / \mathrm{mol}, \mathrm{Mw} / \mathrm{Mn}=1.87$, relative to PS standards). $1 \mathrm{H}$ NMR (500 $\mathrm{MHz}, \mathrm{CDCl} 3, \delta) 8.46$ (s, ArH of anthracene), 8.32 (s, ArH of anthracene), 7.99 (s, ArH of anthracene), 7.60-7.20 (m, ArH of anthracene), 6.15 (s, CH2-anthracene), 4.80-4.34 (br, NH of PU), 4.30-4.00 (m, $\mathrm{CH} 2 \mathrm{OC}=\mathrm{O}$ of PU), 3.70-3.50 (m, $\mathrm{CH} 2 \mathrm{OH}$ and $\mathrm{CH} 2 \mathrm{~N}=\mathrm{C}=\mathrm{O}$ end group protons of $\mathrm{PU}), 3.20-2.85(\mathrm{~m}, \mathrm{CH} 2 \mathrm{NHC}=\mathrm{O}$ of $\mathrm{PU})$, 1.50-0.80 (m, CCH3 and (CH2)4 of PU).

\subsubsection{Synthesis of 4-(2-hydroxyethyl)-10-oxa-4-azatricyclo[5.2.1.02,6]dec-8-ene}

\section{3,5- dione}

The adduct $1(10 \mathrm{~g}, 60 \mathrm{mmol})$ was suspended in methanol ( $150 \mathrm{~mL})$ and the mixture was cooled to $0{ }^{\circ} \mathrm{C}$. A solution of ethanolamine $(3.6 \mathrm{~mL}, 60 \mathrm{mmol})$ in $30 \mathrm{~mL}$ of methanol was added dropwise $(10 \mathrm{~min})$ to the reaction mixture, and the resulting solution was stirred for $5 \mathrm{~min}$ at $0{ }^{\circ} \mathrm{C}$, then $30 \mathrm{~min}$ at ambient temperature, and finally refluxed for $8 \mathrm{~h}$. After cooling the mixture to ambient temperature, solvent was removed under reduced pressure, and residue was dissolved in $150 \mathrm{~mL}$ of $\mathrm{CH} 2 \mathrm{Cl} 2$ and washed with $3 \times 100 \mathrm{~mL}$ of water. The organic layer was separated, dried over Na2SO4 and filtered. Removal of the solvent under reduced pressure gave white-off solid which was further purified by flash chromatography eluting with ethylacetate (EtOAc) to give the product as a white solid. (Yield= $4.9 \mathrm{~g}, 40 \%$ ). $\mathrm{Mp}=$ 138-139 ${ }^{\circ} \mathrm{C}(\mathrm{DSC}) .1 \mathrm{H}$ NMR $(\mathrm{CDCl} 3, \delta) 6.51$ (s, 2H, $\mathrm{CH}=\mathrm{CH}$, bridge protons), 5.26 (s, 2H, -CHO, bridge-head protons), 3.74-3.68 (m, 4H, NCH2CH2OH), $2.88(\mathrm{~s}, 2 \mathrm{H}$, $\mathrm{CH}-\mathrm{CH}$, bridge protons). 13C NMR (CDCl3, $\delta)$ 177.03, 136.60, 81.09, 60.53, 47.74, 42.03 .

\subsubsection{Preparation of furan-protected maleimide-end-functionalized PEG (PEG-MI)}

Me-PEG20 $(\mathrm{Mn}=840 \mathrm{~g} / \mathrm{mol})(2.0 \mathrm{~g}, 3.63 \mathrm{mmol})$ was dissolved in $50 \mathrm{~mL}$ of $\mathrm{CH} 2 \mathrm{Cl} 2$. To the reaction mixture were added DMAP $(0.044 \mathrm{~g}, 0.363 \mathrm{mmol})$ and 3 $(2.24 \mathrm{~g}, 7.27 \mathrm{mmol})$ in that order. After stirring $5 \mathrm{~min}$ at room temperature, a solution of DCC $(1.49 \mathrm{~g}, 7.27 \mathrm{mmol})$ in $10 \mathrm{~mL}$ of $\mathrm{CH} 2 \mathrm{Cl} 2$ was added. Reaction mixture was 
stirred for overnight at room temperature. After filtration off the salt, the solution was concentrated and the viscous brown color product was purified by column chromatography over silica gel eluting with $\mathrm{CH} 2 \mathrm{Cl} 2 / \mathrm{EtOAc}$ mixture $(1: 1, \mathrm{v} / \mathrm{v})$ and then with $\mathrm{CH} 2 \mathrm{Cl} 2 /$ methanol $(90: 10, \mathrm{v} / \mathrm{v})$ to obtain MI-PEG as viscous brown oil. Yield: $2.7 \mathrm{~g}(88 \%)$. 1H NMR $(\mathrm{CDCl} 3, \delta) 6.50$ (s, 2H, $\mathrm{CH}=\mathrm{CH}$ as bridge protons), $5.24(\mathrm{~s}, 2 \mathrm{H},-\mathrm{CHO}$, bridge-head protons), $4.21(\mathrm{~m}, 4 \mathrm{H}, \mathrm{CH} 2 \mathrm{OC}=\mathrm{O}), 3.74-3.53(\mathrm{~m}$, $\mathrm{OCH} 2 \mathrm{CH} 2$ repeating unit of $\mathrm{PEG}, \mathrm{C}=\mathrm{ONCH} 2$, and $\mathrm{CH} 2-\mathrm{PEG}$ repeating unit), 3.36 (s, 3H, PEG-OCH3), $2.86(\mathrm{~s}, 2 \mathrm{H}, \mathrm{CH}-\mathrm{CH}$, bridge protons) 2.61-2.56 (m, 4H, $\mathrm{C}=\mathrm{OCH} 2 \mathrm{CH} 2 \mathrm{C}=\mathrm{O})$.

\subsubsection{Preparation of furan-protected maleimide-end-functionalized PMMA (PMMA-MI)}

In a $25 \mathrm{~mL}$ of Schlenk tube, MMA (5.0 mL, $47 \mathrm{mmol})$, PMDETA $(0.20 \mathrm{~mL}, 0.94$ $\mathrm{mmol}), \mathrm{CuCl}(0.093 \mathrm{~g}, 0.94 \mathrm{mmol})$, toluene $(5 \mathrm{~mL})$, and 2-bromo-2-methylpropionic acid 2-(3,5-dioxo-10-oxa-4-azatricyclo[5.2.1.02,6]dec-8-en-4-yl)-ethyl ester $(0.34 \mathrm{~g}, 0.94 \mathrm{mmol})$ were added, and the reaction mixture was degassed by FPT cycles, and left in argon. The tube was then placed in a thermostated oil bath at $40{ }^{\circ} \mathrm{C}$ for a predetermined time. The polymerization mixture was diluted with THF, passed through a basic alumina column to remove the catalyst, and precipitated into hexane. The polymer was dried for $24 \mathrm{~h}$ in a vacuum oven at $40{ }^{\circ} \mathrm{C}(\mathrm{Mn}$, theo $=2800$ $\mathrm{g} / \mathrm{mol}, \mathrm{Mn}, \mathrm{NMR}=2700 \mathrm{~g} / \mathrm{mol}, \mathrm{Mn}, \mathrm{GPC}=2500 \mathrm{~g} / \mathrm{mol}, \mathrm{Mw} / \mathrm{Mn}=1.32) .1 \mathrm{H} \mathrm{NMR}$ (500 MHz, CDCl3, d) 6.54 (s, 2H, $\mathrm{CH}=\mathrm{CH}$, bridge protons), 5.27 (s, 2H, $-\mathrm{CHO}$, bridge-head protons), 4.17 and $4.12(\mathrm{~m}, 2 \mathrm{H}, \mathrm{NCH} 2 \mathrm{CH} 2 \mathrm{OC}=\mathrm{O}), 3.75-3.50(\mathrm{~m}, \mathrm{OCH} 3$ of PMMA and $\mathrm{NCH} 2 \mathrm{CH} 2 \mathrm{OC}=\mathrm{O}$ ), 2.91 (s, 2H, $\mathrm{CH}-\mathrm{CH}$, bridge protons), 2.20-0.75 (m, aliphatic protons of PMMA).

\subsubsection{Synthesis of Diels-Alder model reaction of PU-anthracene with 4-(2- hydroxyethyl)-10-oxa-4-azatricyclo[5.2.1.02,6]dec-8-ene-3,5-dione, 2 (PU-g-2)}

PU-anthracene $(0.100 \mathrm{~g}, 0.203 \mathrm{mmol}$ of anthracene, 1 equiv) and 2 (0.0558 g, 0.305 mmol, 1.5 equiv) were dissolved in $30 \mathrm{~mL}$ of dioxane/toluene mixture $(2: 1, \mathrm{v} / \mathrm{v})$. Following that, the solution was bubbled with nitrogen for $30 \mathrm{~min}$ and refluxed at $105^{\circ} \mathrm{C}$ in the dark for $24 \mathrm{~h}$. The solution was evaporated to dryness and the residual solid was dissolved in THF, and subsequently precipitated in $50 \mathrm{~mL}$ of diethyl ether. This dissolution-precipitation procedure (THF-ether) was repeated two times and the 
obtained product was dried in a vacuum oven at $40{ }^{\circ} \mathrm{C}$ for $24 \mathrm{~h}$ (Yield $=0.123 \mathrm{~g}$, $90 \%, \mathrm{Mn}, \mathrm{GPC}=9350 \mathrm{~g} / \mathrm{mol}, \mathrm{Mw} / \mathrm{Mn}=1.52$, relative to PS standards). $1 \mathrm{H} \mathrm{NMR}$ (500 MHz, CDCl3, \&) 7.50-7.00 (m, ArH), 5.60-5.00 (m, CH2-Diels-Alder adduct and $\mathrm{NH}$ of PU), 4.78 (s, CH, bridge-head proton), 4.40-4.05 (m, $\mathrm{CH} 2 \mathrm{OC}=\mathrm{O}$ of $\mathrm{PU}$ ), 3.70-3.50 (m, $\mathrm{CH} 2 \mathrm{OH}$ and $\mathrm{CH} 2 \mathrm{~N}=\mathrm{C}=\mathrm{O}$ end group protons of $\mathrm{PU}), 3.50-2.90(\mathrm{~m}$, $\mathrm{CH} 2 \mathrm{NHC}=\mathrm{O}$ of $\mathrm{PU}, \mathrm{CH}-\mathrm{CH}$ bridge protons, $\mathrm{OCH} 2 \mathrm{CH} 2 \mathrm{~N}, \mathrm{OCH} 2 \mathrm{CH} 2 \mathrm{~N}), 1.50-1.00$ (br, $\mathrm{CCH} 3$ and $(\mathrm{CH} 2) 4$ of PU).

\subsubsection{Synthesis of PU-g-PEG copolymer via Diels-Alder reaction between PU- anthracene and PEG-MI}

PU-anthracene (0.100 g, $0.203 \mathrm{mmol}$ of anthracene, 1 equiv) and PEG-MI (0.204 g, $0.244 \mathrm{mmol}, \mathrm{Mn}$,theo= $840 \mathrm{~g} / \mathrm{mol}, 1.2$ equiv) were dissolved in $30 \mathrm{~mL}$ of dioxane/toluene mixture $(2: 1, \mathrm{v} / \mathrm{v})$. The reaction mixture was bubbled with nitrogen for $30 \mathrm{~min}$ and refluxed at $105^{\circ} \mathrm{C}$ in the dark for $48 \mathrm{~h}$. It was evaporated to dryness, and the residual solid was dissolved in THF, and subsequently precipitated in $50 \mathrm{~mL}$ of diethyl ether. The remaining solid was isolated by decantation. This dissolutionprecipitation procedure (THF-ether) was repeated two times and the obtained product was dried in a vacuum oven at $40{ }^{\circ} \mathrm{C}$ for $24 \mathrm{~h}$ (Yield $=0.14 \mathrm{~g}, 52 \%, \mathrm{Mn}, \mathrm{GPC}=$ $11600 \mathrm{~g} / \mathrm{mol}, \mathrm{Mw} / \mathrm{Mn}=1.45$, relative to PS standards). 1H NMR (500 MHz, CDCl3, б) 7.50-7.00 (m, ArH), 5.45 (bs, CH2-Diels-Alder adduct), 5.20-4.90 (br, NH of PU), 4.74 (s, CH, bridge-head proton), 4.40-4.00 (bs, $\mathrm{CH} 2 \mathrm{OC}=\mathrm{O}$ of $\mathrm{PU}$ and $\mathrm{C}=\mathrm{OOCH} 2 \mathrm{CH} 2), 3.90-2.80(\mathrm{~m}, \mathrm{CH} 2 \mathrm{OH}$ and $\mathrm{CH} 2 \mathrm{~N}=\mathrm{C}=\mathrm{O}$ end group protons of $\mathrm{PU}$, $\mathrm{OCH} 2 \mathrm{CH} 2$ of $\mathrm{PEG}, \mathrm{C}=\mathrm{OOCH} 2 \mathrm{CH} 2 \mathrm{~N}, \mathrm{C}=\mathrm{OOCH} 2 \mathrm{CH} 2 \mathrm{~N}, \mathrm{OCH} 3$ end-group of $\mathrm{PEG}$ and $\mathrm{CH}-\mathrm{CH}$ bridge protons, $\mathrm{CH} 2 \mathrm{NHC}=\mathrm{O}$ of $\mathrm{PU}$ ), 2.70-2.40 (br, $\mathrm{C}=\mathrm{OCH} 2 \mathrm{CH} 2 \mathrm{C}=\mathrm{O}$ ), 1.50-1.00 (m, CCH3 and (CH2)4 of PU).

\subsubsection{Synthesis of PU-g-PMMA copolymer via Diels-Alder reaction between PU-anthracene and PMMA-MI}

PU-anthracene (0.100 g, $0.203 \mathrm{mmol}$ of anthracene, 1 equiv) and PMMA-MI (0.609 $\mathrm{g}, 0.244 \mathrm{mmol}, \mathrm{Mn}, \mathrm{GPC}=2500 \mathrm{~g} / \mathrm{mol}, 1.2$ equiv) were dissolved in $30 \mathrm{~mL}$ of dioxane/toluene mixture $(2: 1, \mathrm{v} / \mathrm{v})$. Following that, the solution was bubbled with nitrogen for $30 \mathrm{~min}$ and refluxed at $105^{\circ} \mathrm{C}$ in the dark for $48 \mathrm{~h}$. The solution was evaporated to dryness and the residual solid was dissolved in THF, and subsequently precipitated in methanol/diethyl ether mixture $(1: 1, \mathrm{v} / \mathrm{v})$. This dissolution- 
precipitation procedure was repeated two times and the obtained product was dried in a vacuum oven at $40^{\circ} \mathrm{C}$ for $24 \mathrm{~h}$ (Yield $=0.5 \mathrm{~g}, 80 \%, \mathrm{Mn}, \mathrm{GPC}=23800 \mathrm{~g} / \mathrm{mol}$, $\mathrm{Mw} / \mathrm{Mn}=1.65$, relative to PS standards). 1H NMR (500 MHz, $\mathrm{CDCl} 3, \delta) 7.50-7.00$ (m, ArH), 5.48 (bs, CH2-Diels-Alder adduct), 5.20-4.90 (br, NH of PU), 4.79 (s, $\mathrm{CH}$, bridge-head proton), 4.30-4.00 (m, $\mathrm{CH} 2 \mathrm{OC}=\mathrm{O}$ of $\mathrm{PU}), 3.90-2.90(\mathrm{~m}, \mathrm{CH} 2 \mathrm{OH}$ and $\mathrm{CH} 2 \mathrm{~N}=\mathrm{C}=\mathrm{O}$ end group protons of $\mathrm{PU}, \mathrm{OCH} 3$ of $\mathrm{PMMA}, \mathrm{C}=\mathrm{OOCH} 2 \mathrm{CH} 2 \mathrm{~N}$, $\mathrm{C}=\mathrm{OOCH} 2 \mathrm{CH} 2 \mathrm{~N}, \mathrm{CH}-\mathrm{CH}$ bridge protons and $\mathrm{CH} 2 \mathrm{NHC}=\mathrm{O}$ of $\mathrm{PU}), 1.50-0.80(\mathrm{~m}$, $\mathrm{CH} 2$ and $\mathrm{CH} 3$ of PMMA, $\mathrm{CCH} 3$ and $(\mathrm{CH} 2) 4$ of $\mathrm{PU})$. 


\section{RESULTS AND DISCUSSION}

\subsection{Synthesis of Adduct Functional Structures}

Maleic anhydride and furan were reacted in toluene at reflux temperature for $8 \mathrm{~h}$ to give 4,10-dioxatricyclo[5.2.1.02,6]dec-8-ene-3,5-dione , 1 (Fig. 4.1). The anhydride 1 (maleimide) was obtained as small white needles.

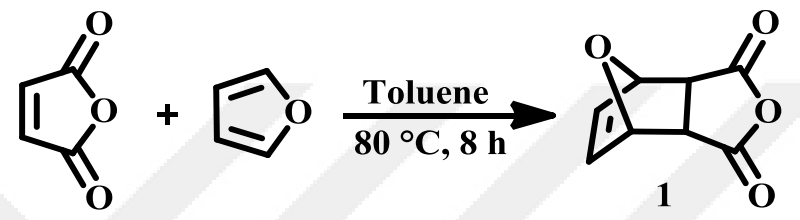

Figure 4.1: Formation of the adduct.

The reaction of the anhydride 1 (maleic anhydride) was then carried out to give the 4-(2-Hydroxyethyl)-10-oxa-4-azatricyclo[5.2.1.02,6]dec-8-ene-3,5- dione, 2 . In this reaction, the anhydride 1 was suspended in $\mathrm{MeOH}$ and a solution of ethanolamine in $\mathrm{MeOH}$ was added at $0{ }^{\circ} \mathrm{C}$, then the mixture refluxed for $8 \mathrm{~h}$ (Fig. 4.2). Finally, compound 2 (adduct alcohol) was obtained as a white solid.

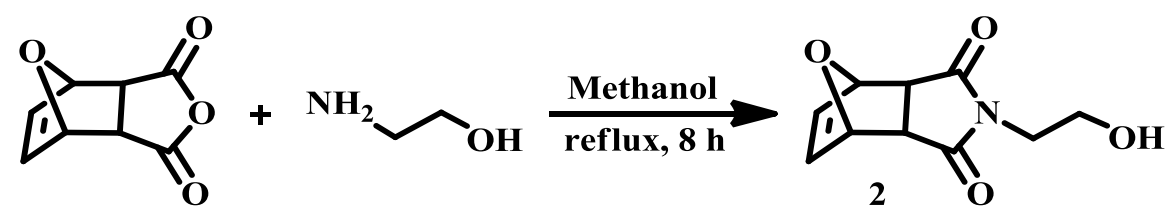

Figure 4.2: Formation of the adduct alcohol.

The synthesis of 2-bromo-2-methyl-propionic acid 2-(3,5-dioxo-10-oxa-4azatricyclo[5.2.1.02,6]dec-8-en-4-yl) ethyl ester 3 was obtained via an esterification reaction between 2 and 2-bromoisobutryl bromide in THF at room temperature (Fig. 4.3). Thus, the initiators with proper functionalities for DA reaction were first prepared. 


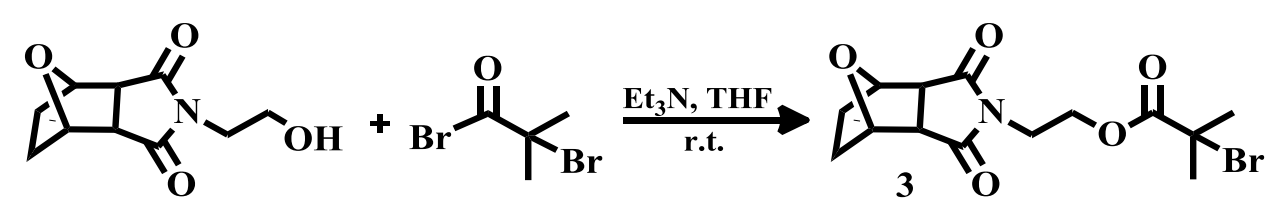

Figure 4.3: The synthesis of 2-bromo-2-methyl-propionic acid 2-(3,5-dioxo-10-oxa4-azatricyclo[5.2.1.02,6]dec-8-en-4-yl) ethyl ester.

The hydoxyl functionality of 2 was converted to carboxylic acid via a reaction with succinic anhydride in the presence of Et3N/DMAP catalyst system and 1,4-dioxane as solvent in order to give the 4-(2-\{[(3-acetyl-7-oxabicyclo[2.2.1]heptyl)carbonyl]amino \}ethoxy)-4-oxobutanoic acid, 4 (Fig. 4.4).

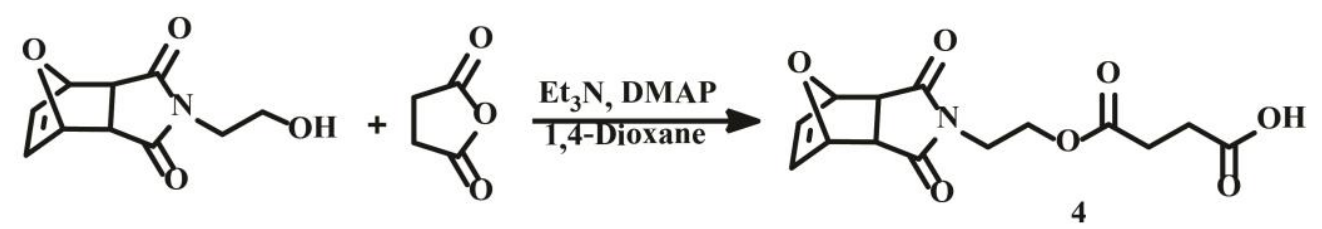

Figure 4.4: The synthesis of 4-(2-\{[(3-acetyl-7-oxabicyclo[2.2.1]heptyl)carbonyl]amino ethoxy)-4-oxobutanoic acid.

From overlay 1H NMR spectra Figure 4.5 of 4, methylene protons next to the ester $(\mathrm{NCH} 2 \mathrm{CH} 2 \mathrm{OC}=\mathrm{O})$ and methylene protons adjacent to nitrogen $(\mathrm{NCH} 2 \mathrm{CH} 2 \mathrm{OC}=\mathrm{O})$ appeared at $4.25 \mathrm{ppm}$ and $3.74 \mathrm{ppm}$ respectively. Moreover, the multiplet peaks around 2.66-2.53 ppm confirmed successful conversion of hydroxyl group to carboxylic acid. From spectrum (c), it is clearly seen that the methyl protons next to Br were detected at $1.87 \mathrm{ppm}$ and the methylene protons next to the ester unit at 4.31 ppm. Moreover, the characteristic protons of the adduct were also detected at 6.49 ppm (bridge vinyl protons), $5.24 \mathrm{ppm}$ (bridge-head protons) and $2.85 \mathrm{ppm}$ (bridge protons) respectively. These results confirmed that the synthesis of 3 was achived. 

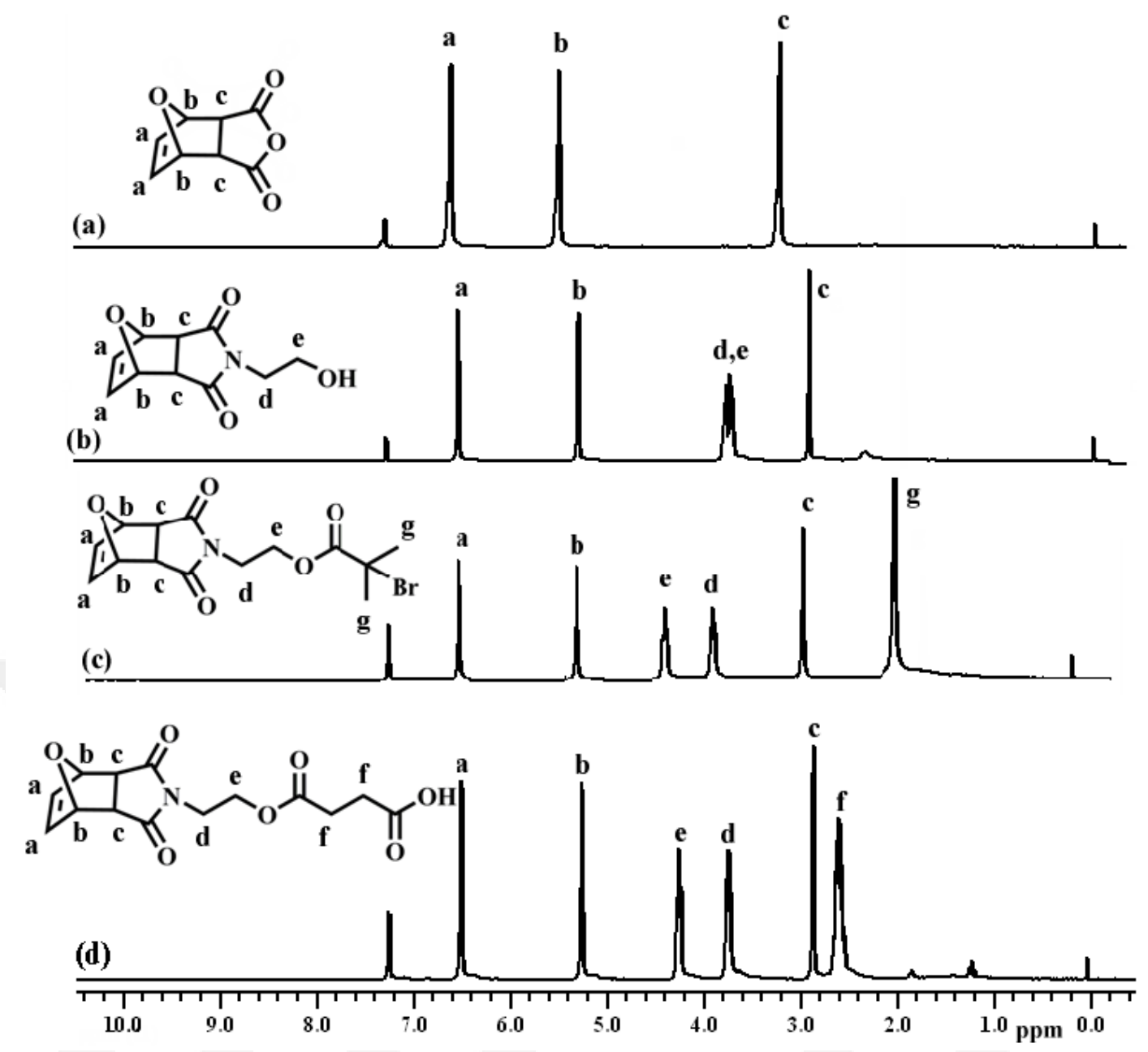

Figure 4.5: Overlay 1H-NMR spectra of the compounds.

a) 3-acetyl-N-(2-hydroxyethyl)-7-oxabicyclo[2.2.1]hept-5-ene-2-carboxylic acid (1);

b) 3-acetyl-N-(2-hydroxyethyl)-7-oxabicyclo[2.2.1]hept-5-ene-2-carboxamide (2); c) 2-bromo-2- methyl-propionic acid 2-(3,5-dioxo-10-oxa-4-azatricyclo[5.2.1.02,6]dec8-en-4-yl) ethyl ester (3); d) 4-(2-\{[(3-acetyl-7-oxabicyclo[2.2.1]heptyl)carbonyl]amino \}ethoxy)-4-oxobutanoic acid (4) in CDCl3.

To synthesize 1-(3,5-bis(trifloromethyl)phenyl)-3-cyclohexylthiourea) is in other world co-catalyst (TU), cyclohexylamine and 3,5-bis(trifluoromethyl)phenyl isothiocyanate were reacted in THF at room temperature for 4 h (Fig.4.6). Finally, compound 5 was obtained as a white solid. 


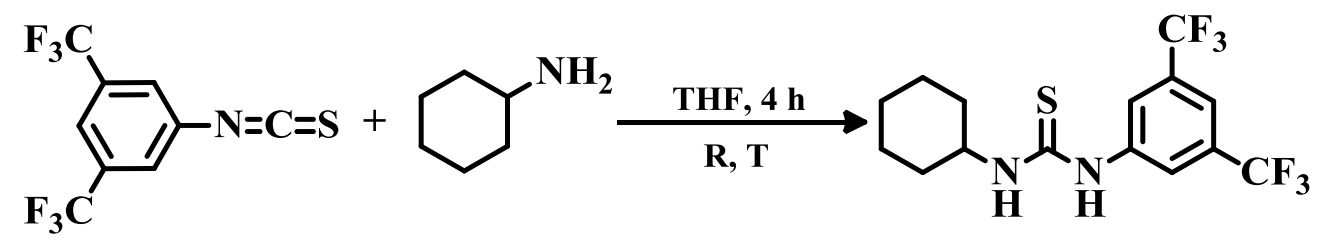

Figure 4.6: The synthesis of 1-(3,5-bis(trifloromethyl)phenyl)-3cyclohexylthiourea).

\subsection{Synthesis of Anthracene Functional Monomers}

2,2,5-Trimethyl-[1,3]dioxane-5-carboxylic acid (1) was synthesized by the reaction between 2,2-bis (hydroxymethyl)-propanoic acid and 2,2-dimethoxy-propane with excess amount of dry acetone using p-toluene sulfonic acid as catalyst.

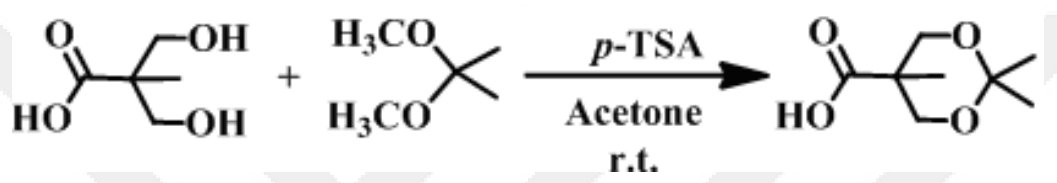

Figure 4.7:Formation of the acid ketal.

1H NMR spectrum of 2,2,5-trimethyl-[1,3]dioxane-5-carboxylic acid, 6 showing resonances corresponding to $-\mathrm{COOH}$ proton at $11.20 \mathrm{ppm}$, methylene groups at 4.18 and 3.63 , the methyl protons adjacent to ketal group and adjacent to methylene groups at $1.38-1.36 \mathrm{ppm}$ and $1.18 \mathrm{ppm}$ respectively.

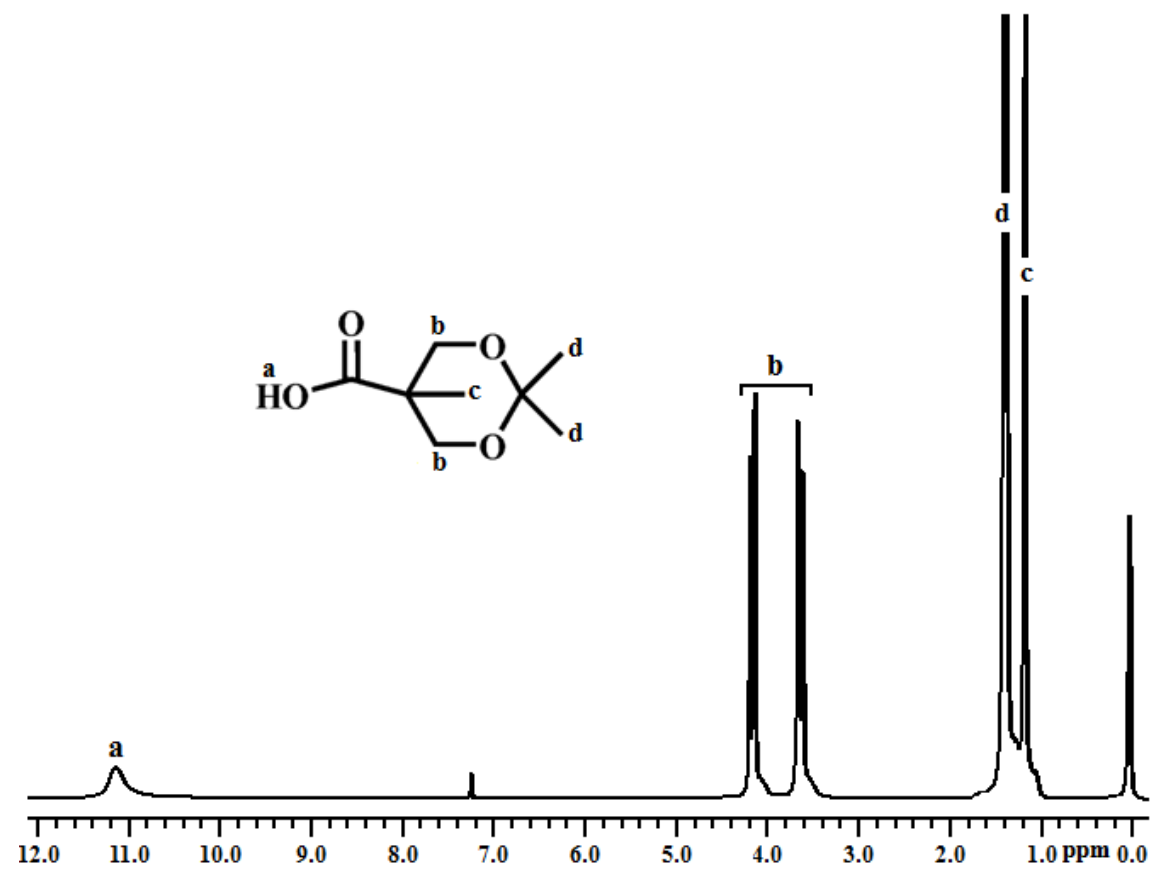

Figure 4.8: $1 \mathrm{H}$ NMR spectrum of 6 in $\mathrm{CDCl} 3$. 
Initially, esterification reaction of anthracen-9-ylmethanol and 2,2,5-trimethyl-1,3dioxane-5-carboxylic acid 6 was prepared to synthesize (anthracen-9-ylmethyl 2,2,5trimethyl-1,3-dioxane-5-carboxylate), 7 by catalyzing DCC and DMAP in $\mathrm{CH} 2 \mathrm{Cl} 2$ at room temperature overnight.

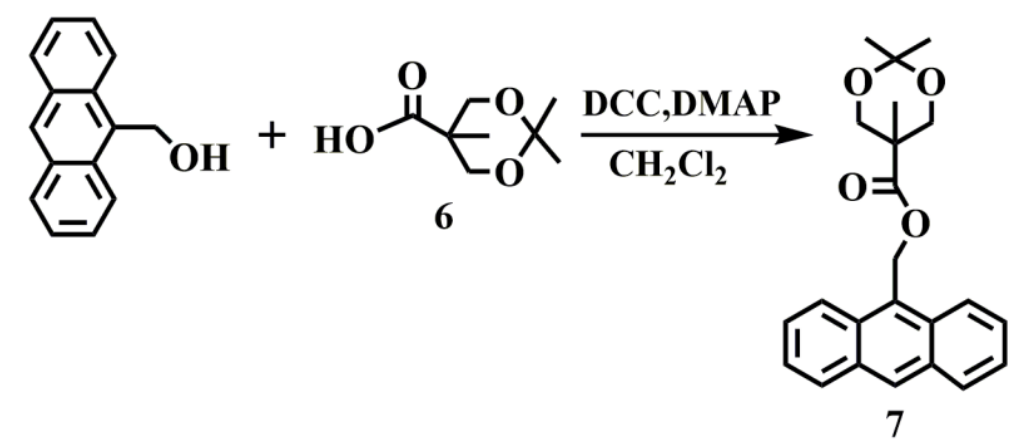

Figure 4.9: Synthesis of the anthracene ketal.

Next, (anthracene-9-ylmethyl 2,2,5-trimethyl-1,3-dioxane-5-carboxylate) 7 was hydrolized in THF by adding $\mathrm{HCl}$ solution stirring for 2 hours at room temperature.
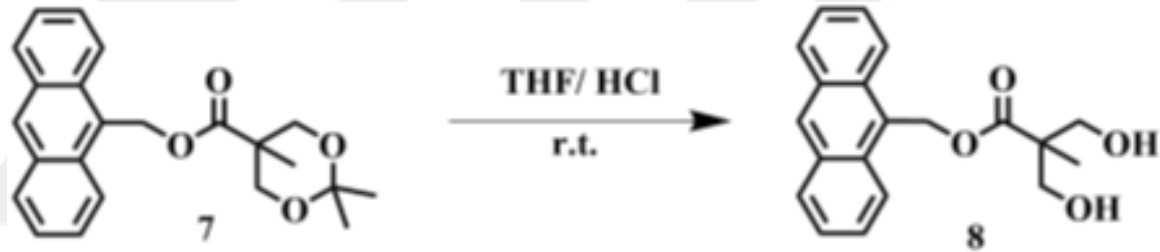

Figure 4.10: Synthesis of the anthracene diol.

Thus, anthracen-9-ylmethyl 3-hydroxy-2-(hydroxymethyl)-2-methylpropanoate 8 was obtained.

\subsection{Synthesis of Co-Catalyst TU}

To synthesize thiourea (TU) 9 co-catalyst simply reacted two compound shown in Figure 4.5 which those are cyclohexylamine and 3,5-bis(trifluoromethyl)phenyl isothiocyanate, respectively. Cyclohexylamine was added dropwise at room temperature to a stirring solution of 3,5-bis(trifluoromethyl)phenyl isothiocyanate using THF as solvent. 


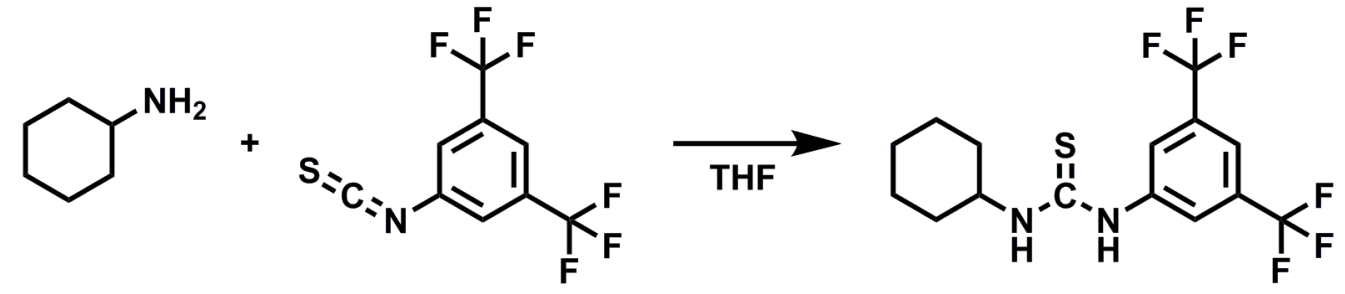

(9)

Figure 4.11: Synthesis of the thiourea derivative.

On the NMR spectrum of 1-(3,5-bis(trifluoromethyl)phenyl)-3-cyclohexyl thiourea (TU) integration values corrected the structure of the compound.

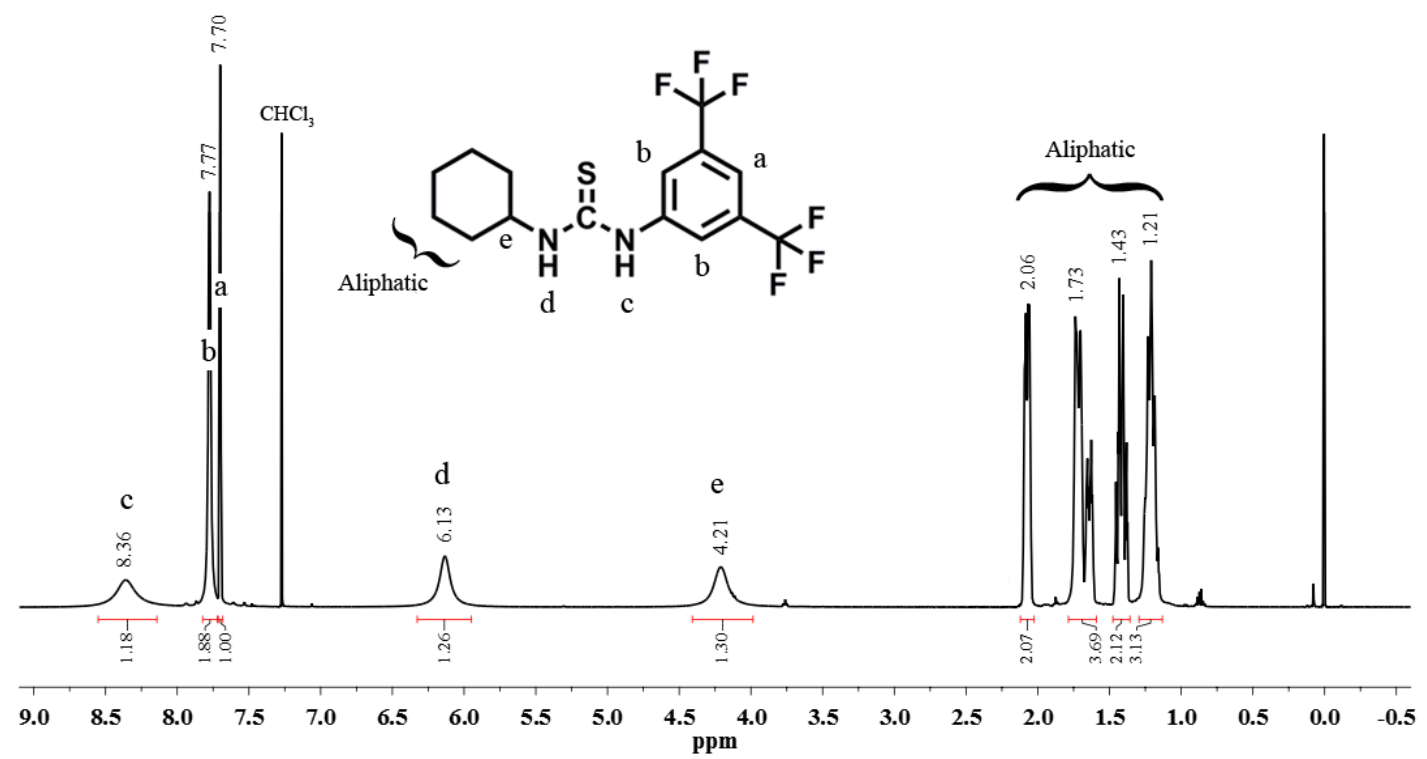

Figure 4.12: 1H-NMR spectrum of 1-(3,5-bis(trifluoromethyl)phenyl)-3-cyclohexyl thiourea (TU) in CDCl3 (500 MHz).

\subsection{Homopolymers and Diels Alder Products}

Diels-Alder reactions have been extensively employed for the post-polymerization functionalization of a wide variety of polymer backbones13,16 as well as for the polymer-polymer conjugation. Therefore, here we explored the use of anthracene diol, 1 for PU-anthracene synthesis, followed by its post-functionalization via DielsAlder reaction using well-defined polymer precursors with a maleimide terminal group (Fig. 4.13). To verify the efficiency of Diels-Alder reaction for grafting onto 
the PU-anthracene, a model reaction of maleimide functional group with the PUanthracene backbone was first studied.
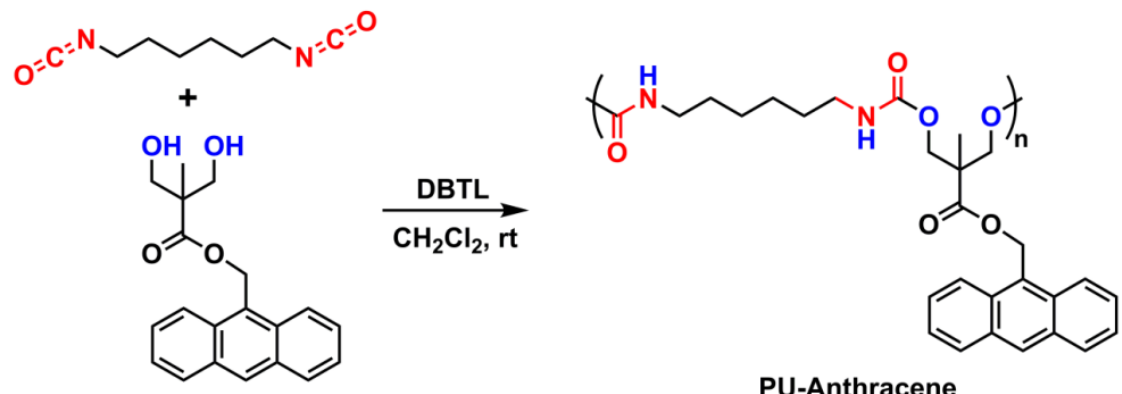

PU-Anthracene

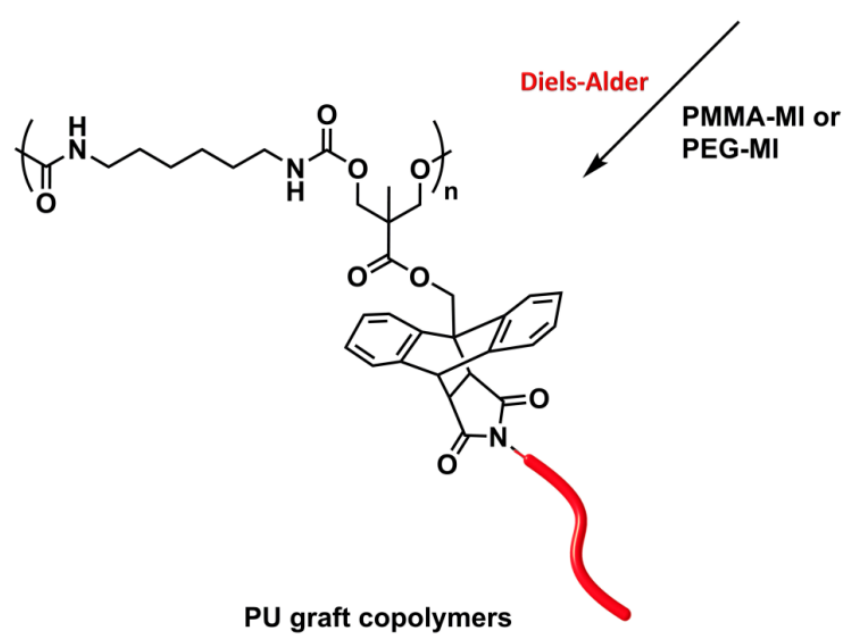

Figure 4.13: . General reaction pathway for the synthesis of PU-graft copolymers.

The linear PU with regular pendant anthracene functional groups (PU-anthracene) was synthesized by step-growth polymerization of anthracene diol, 1 (1 equiv) and HMDI ( 1 equiv) using DBTL (0.05 equiv) as the catalyst in $\mathrm{CH} 2 \mathrm{Cl} 2$ at room temperature for 10 days. 1H NMR spectroscopy confirmed the expected structure of the PU-anthracene primarily displaying the characteristic signals of the ArHs of anthracene and the $\mathrm{CH} 2 \mathrm{NHC}=\mathrm{O}$ of $\mathrm{PU}$ backbone at 8.46-7.20 and 3.20-2.85 ppm, respectively. Notably, an integrated ratio of the ArHs of anthracene unit to the $\mathrm{CH} 2 \mathrm{NHC}=\mathrm{O}$ of $\mathrm{PU}$ was found to be 9:4, indicating the successful formation of the PU-anthracene. Gel permeation chromatography (GPC) analysis exhibited: Mn,GPC $=12900 \mathrm{~g} / \mathrm{mol}, \mathrm{Mw} / \mathrm{Mn}=1.87$ relative to PS standards in THF at $30 \mathrm{oC}$. 


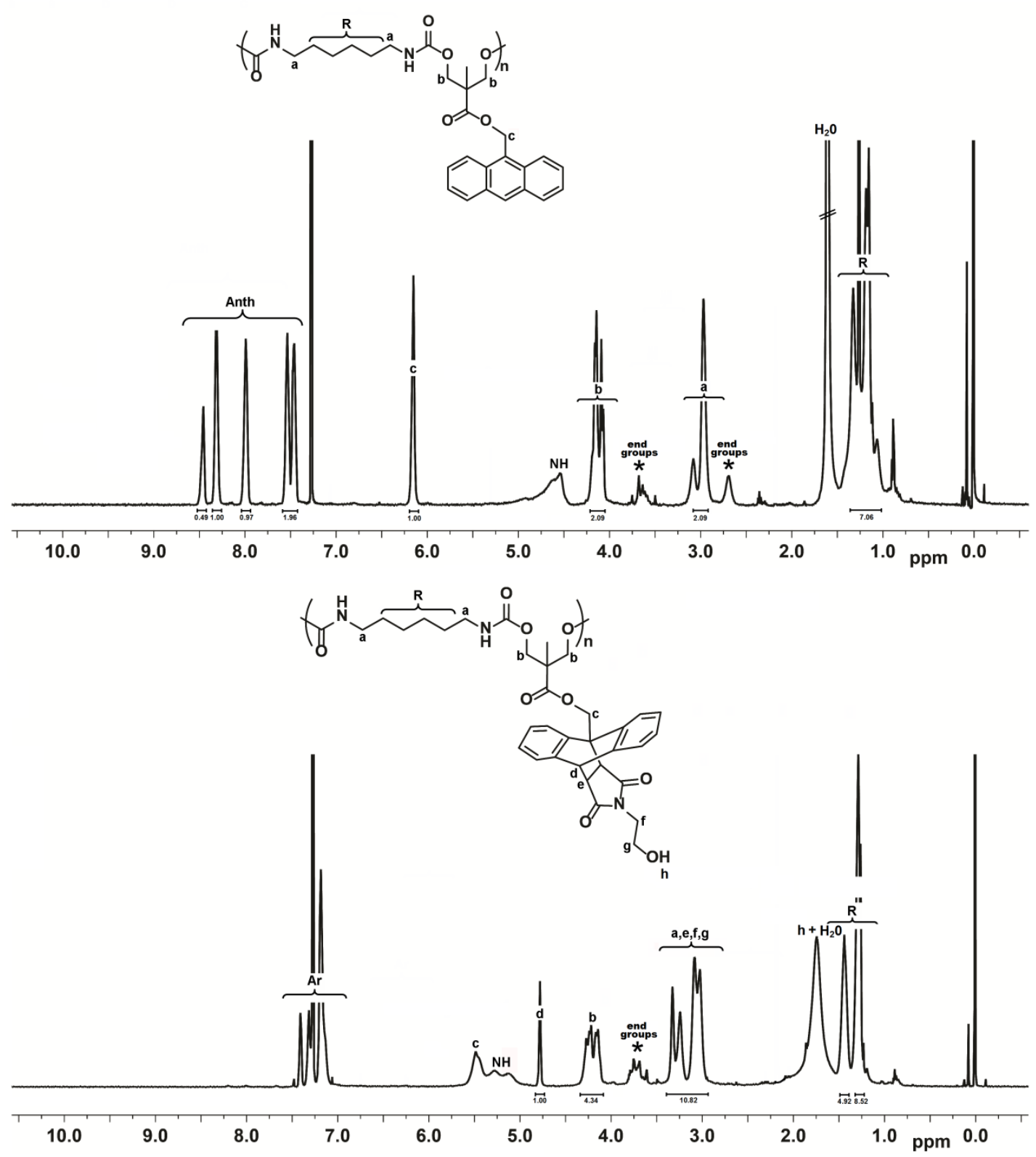

Figure 4.14: $1 \mathrm{H}$ NMR spectra of PU-anthracene and PU-g-2 (model reaction) in $\mathrm{CDCl} 3(500 \mathrm{MHz})$.

A model reaction between the PU-anthracene and the maleimide functional compound, 2 was accomplished to determine the efficiency of Diels-Alder click reaction prior to the synthesis of PU-graft copolymers (Fig. 4.14) The Diels-Alder adduct formation (in dioxane/toluene at $105 \mathrm{oC}$ for $24 \mathrm{~h}$ ) was monitored by UV spectroscopy following the disappearance of the characteristic five-finger absorbance of the anthracene at 300-400 $\mathrm{nm}$ due to the formation of the Diels-Alder adduct (Fig. 4.19). The Diels-Alder reaction efficiency was calculated to be $>99 \%$ using an equation given in ref. 13, and thus, indicating a quantitative functionalization of 2 
onto the PU backbone in order to yield PU-g-2. Moreover, the PU-g-2 was also subsequently analyzed by $1 \mathrm{H}$ NMR spectroscopy. Remarkably, 1H NMR revealed a complete disappearance of ArH signals assignable to the anthracene at 8.46, 8.32 and $7.99 \mathrm{ppm}$ and the appearance of new signals regarding the $\mathrm{CH} 2$ linked to the adduct and the $\mathrm{CH}$ (bridge-head) at 5.48 and $4.78 \mathrm{ppm}$, respectively together with signals of 2 (Fig. 4.14). An integrated ratio of the $\mathrm{CH} 2 \mathrm{OC}=\mathrm{O}$ in the $\mathrm{PC}$ backbone ( $\delta 4.40-4.05)$ to the $\mathrm{CH}$ (bridge-head proton, $\delta 4.78$ ) also gave a $4: 1$, indicating quantitative DielsAlder click reaction. Therefore, the confirmed structure of the PU-g-2 demonstrates that Diels Alder click reaction can be employed in the preparation of the PU graft copolymers. As a matter of interest, the GPC trace of the PU-g-2 displayed a shift to higher elution time compared to its starting precursor PU-anthracene, while maintaining moderately narrow polydispersity index and monomodal distribution (Fig. 4.20). This may be attributable to that an incorporation of pendant $\mathrm{OH}$ groups onto the PU backbone may cause to adsorption rather than real size exclusion in the GPC using THF as solvent.13,15a,17

Next, the PU-anthracene main backbone was clicked with a PMMA-MI or PEG-MI as a side chain at reflux temperature of dioxane/toluene mixture for $48 \mathrm{~h}$ to result in the final graft copolymers. A 1.2 equiv of the side chains to the repeating anthracene units of the PU main backbone was used to ensure the reaction completion. The efficiency of Diels-Alder reactions was monitored by UV measurements in the range of 300-400 nm and found to be 99 and 93\% for the PU-g-PMMA and PU-g-PEG, respectively. (Fig 4.21 and 4.22)

A clear shift to the higher molecular weight region was detected from GPC measurements while maintaining moderately narrow polydispersity index and monomodal distribution, except PU-g-PEG, where an adsorption of the graft copolymer to the stationary phase rather than a selective permeation occurred during this operation (Figs. $4.15 \mathrm{a}$ and $\mathrm{b}$ ). 


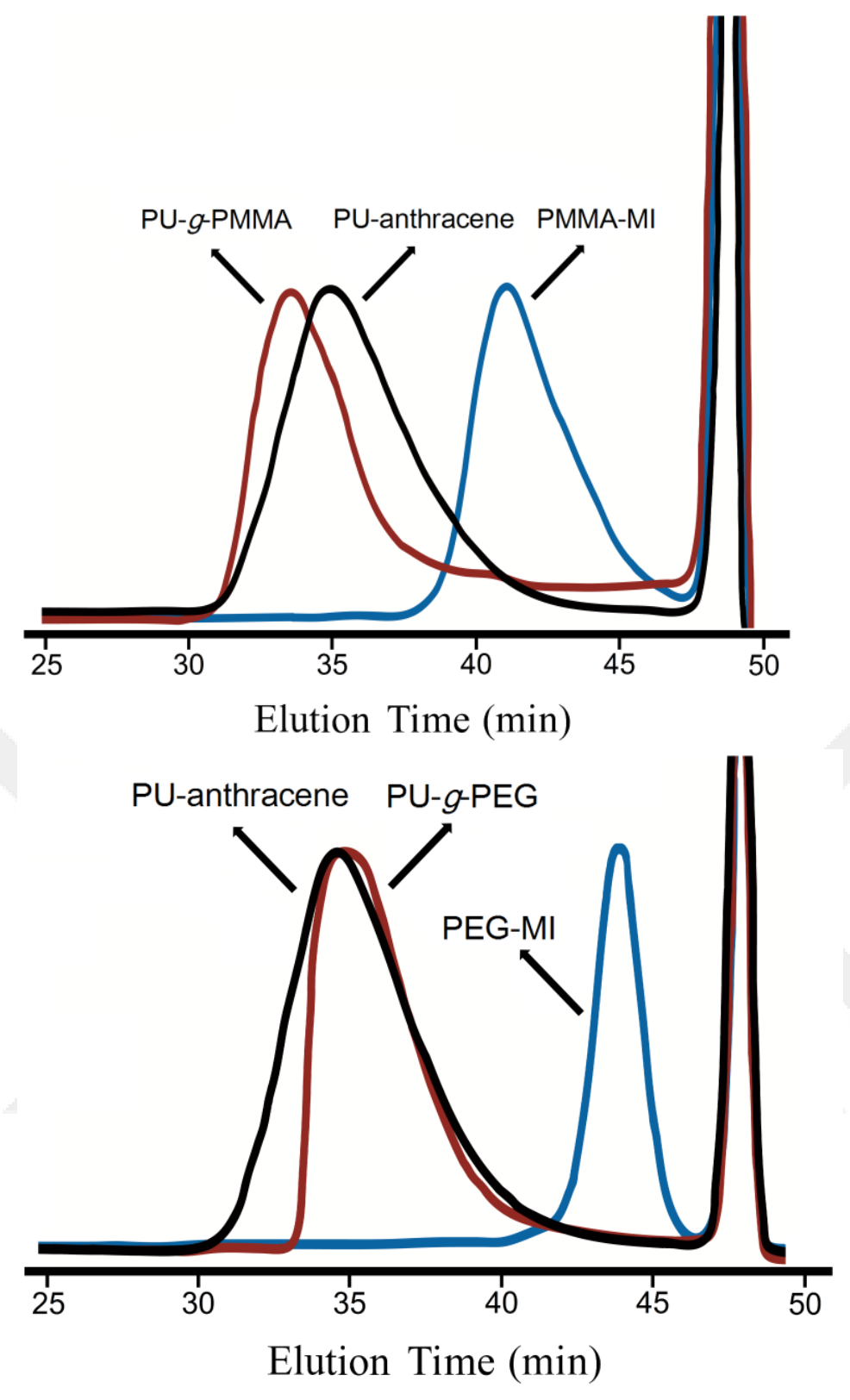

Figure 4.15: Overlays of GPC.

In Figure 4.15, (a) GPC overlays of PU-g-PMMA copolymer, PU-anthracene and PMMA-MI precursors in THF; (b) GPC overlays of PU-g-PEG copolymer, PUanthracene, and PEG-MI precursors in THF. An assessment of the 1H NMR spectrum of the PU-g-PMMA revealed that the resonances related to the ArHs of anthracene at 8.50-7.50 completely had disappeared and two signals regarding the CH2-Diels-Alder adduct and $\mathrm{CH}$ (bridge-head proton) had appeared at 5.48 and 4.79 ppm, respectively (Fig. 4.16). 


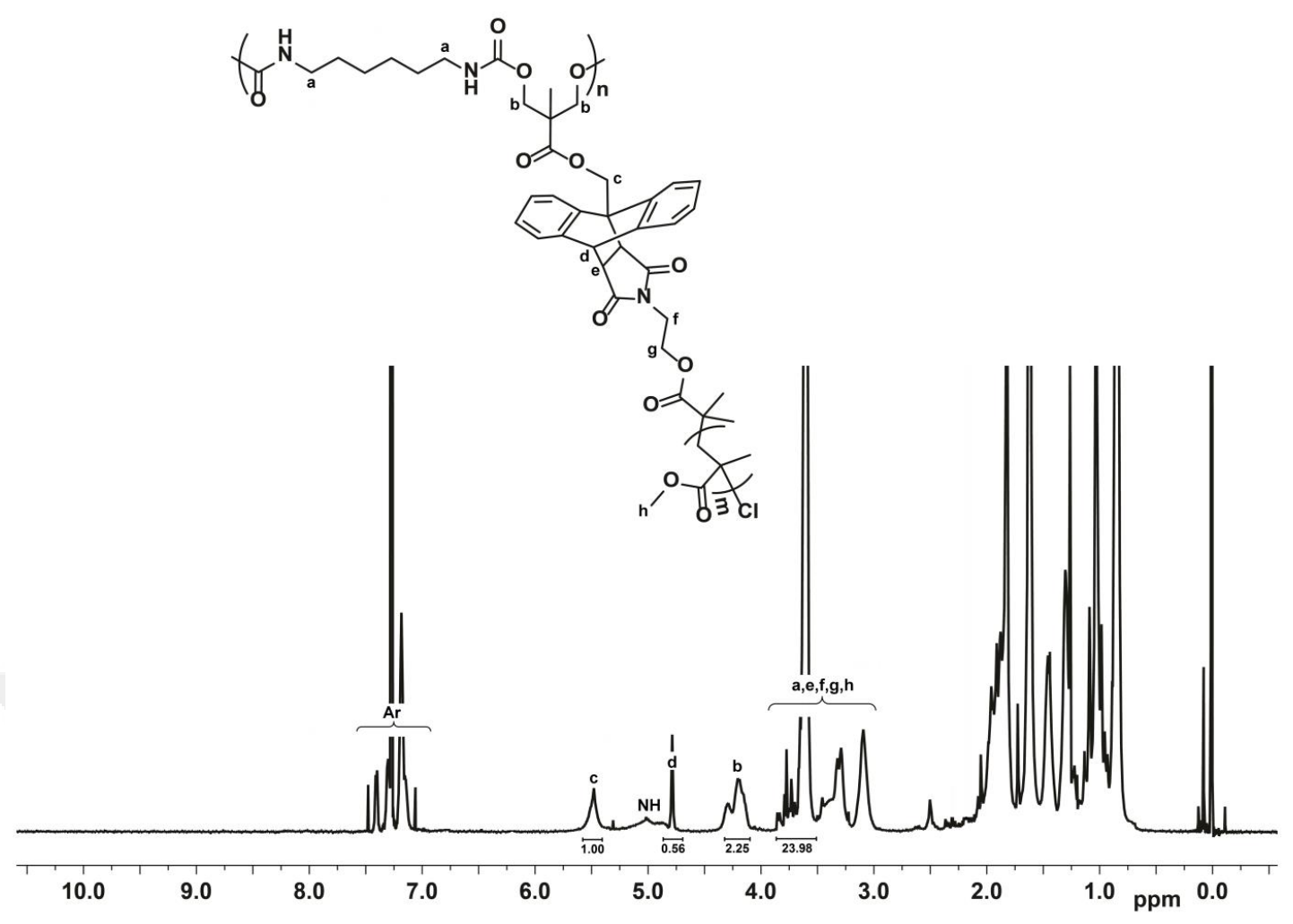

Figure 4.16: 1H NMR spectrum of PU-g-PMMA copolymer in $\mathrm{CDCl} 3(500 \mathrm{MHz})$.

An integrated ratio of the $\mathrm{OCH} 3$ of the PMMA at $3.61 \mathrm{ppm}$ to the $\mathrm{CH} 2$-Diels-Alder adduct of the PU at $5.48 \mathrm{ppm}$ gave the calculated DPn $=16$ of the PMMA side chain incorporated to the PU backbone. It should be noted that this is comparable to the $\mathrm{DPn}=18$ of the linear PMMA precursor.

As a second sample of graft copolymer, the PU-anthracene was subjected to the Diels Alder click reaction with PEG-MI to yield the PU-g-PEG copolymer at reflux temperature of dioxane/toluene for $48 \mathrm{~h}$. The $1 \mathrm{H}$ NMR spectroscopy analysis revealed the presence of both the $\mathrm{CCH} 3 /(\mathrm{CH} 2) 4$ of $\mathrm{PU}$ and the $\mathrm{CH} 2 \mathrm{CH} 2 \mathrm{O}$ of the PEG segments at 1.50-1.00 and 3.74-3.50 ppm, respectively (Fig. 4.17). In addition, a similar calculation based on an integrated ratio of the $\mathrm{OCH} 2 \mathrm{CH} 2$ of the PEG at 3.74-3.50 to the $\mathrm{CCH} 3 /(\mathrm{CH} 2) 4$ of the $\mathrm{PU}(11 \mathrm{H})$ at $1.50-1.00 \mathrm{ppm}$ resulted in the calculated DPn $=9.9$ of the PEG side chain in the PU-g-PEG copolymer being consistent with the DPn $=11$ of the linear PEG precursor. 


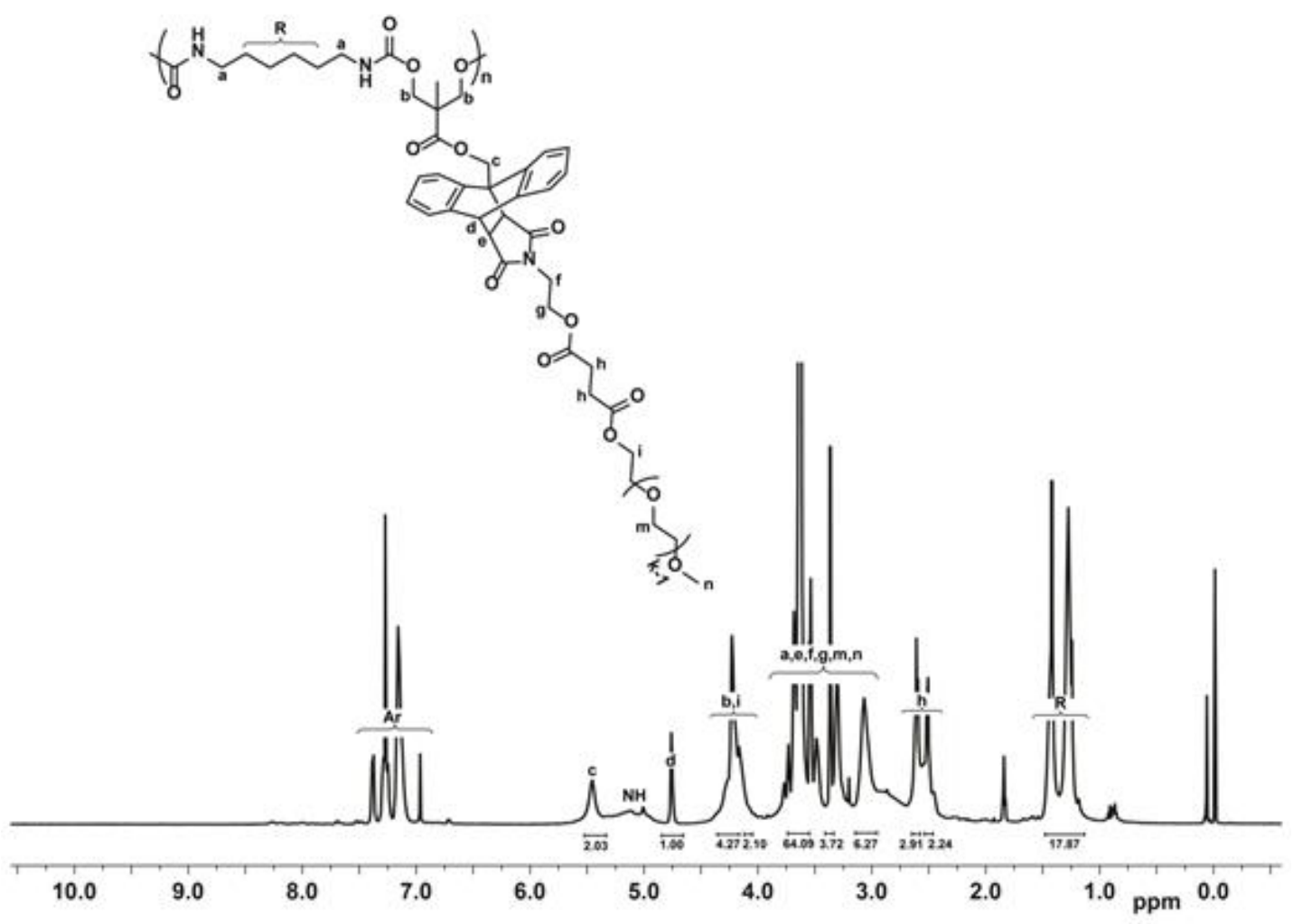

Figure 4.17: 1H NMR spectrum of PU-g-PEG copolymer in CDCl3 (500 MHz).

The thermal transitions from a second heating cycle were measured by DSC at a heating rate of $10 \mathrm{oC} / \mathrm{min}$ under nitrogen. The PU-anthracene exhibited a glass transition (Tg) at $730 \mathrm{C}$ (Fig. 4.18). When the PU-anthracene was modified by reacting with 2 in order to give PU-g-2, the higher Tg at 99oC was observed. The higher Tg of PU-g-2 suggests that an extra contribution of the $\mathrm{OH}$ groups to the intermolecular hydrogen bonding associated with urethane groups exists. Any Tg of the PU-g-PEG copolymer could not be detected due to the fact that maybe an incorporation of the PEG chains might have increased the crystallinity of the PU-gPEG copolymer and thus have decreased the intensity of the Tg signal. . For the PUg-PMMA copolymer, only one $\mathrm{Tg}$ at $113 \mathrm{oC}$, which may be attributed to PMMA grafts was observed. Moreover, it should be noted that the lack of existence of a $\mathrm{Tg}$ value for the PU backbone, might have caused due to the chain stiffness arising from the incorporation of PMMA side chains [17]. 


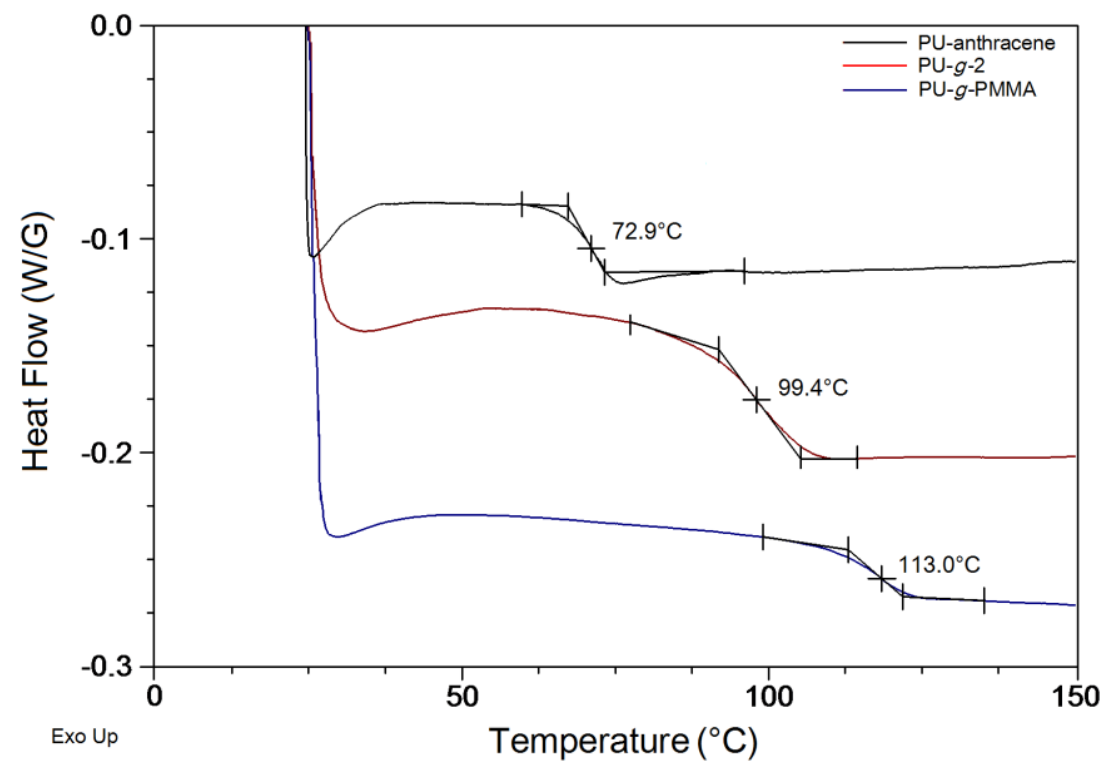

Figure 4.18: DSC thermograms of PU-anthracene, PU-g-2 (model reaction), and PU-g-PMMA copolymer at a heating rate of $10 \mathrm{oC} / \mathrm{min}$ in nitrogen.

TGA measurements of PU-anthracene, PU-g-2, PU-g-PMMA and PU-g-PEG were carried out via TGA Q50 at a heating rate of $10 \mathrm{oC} / \mathrm{min}$ under nitrogen. The degradation of PU-anthracene starts in the range of $250-300 \mathrm{oC}$, which is consistent with the literature [18]. From the TGA thermograms of the PU-g-2 and PU-g-PMMA copolymers, it is deduced that these polymers displayed two degradation processes in the ranges of 250-350oC and 350-450oC (Fig. 4.23). For the PU-g-PMMA, it can be described that the first step corresponds to the degradation of the PU backbone followed by the depolymerization of PMMA grafts as a second step. In the literature, it is given that the PMMA with saturated end groups is thermally stable up to $300 \mathrm{oC}$ in nitrogen atmosphere.18 For the PU-g-2 case, the degradation of the PU main backbone is followed by evolving the compound 2 by retro Diels-Alder reaction. As a matter of interest, the TGA thermogram of the PU-g-PEG copolymer displayed one step degradation process similar to that of PU-anthracene. It may be concluded that the degradation of both PU backbone and PEG grafts occurred concurrently. 


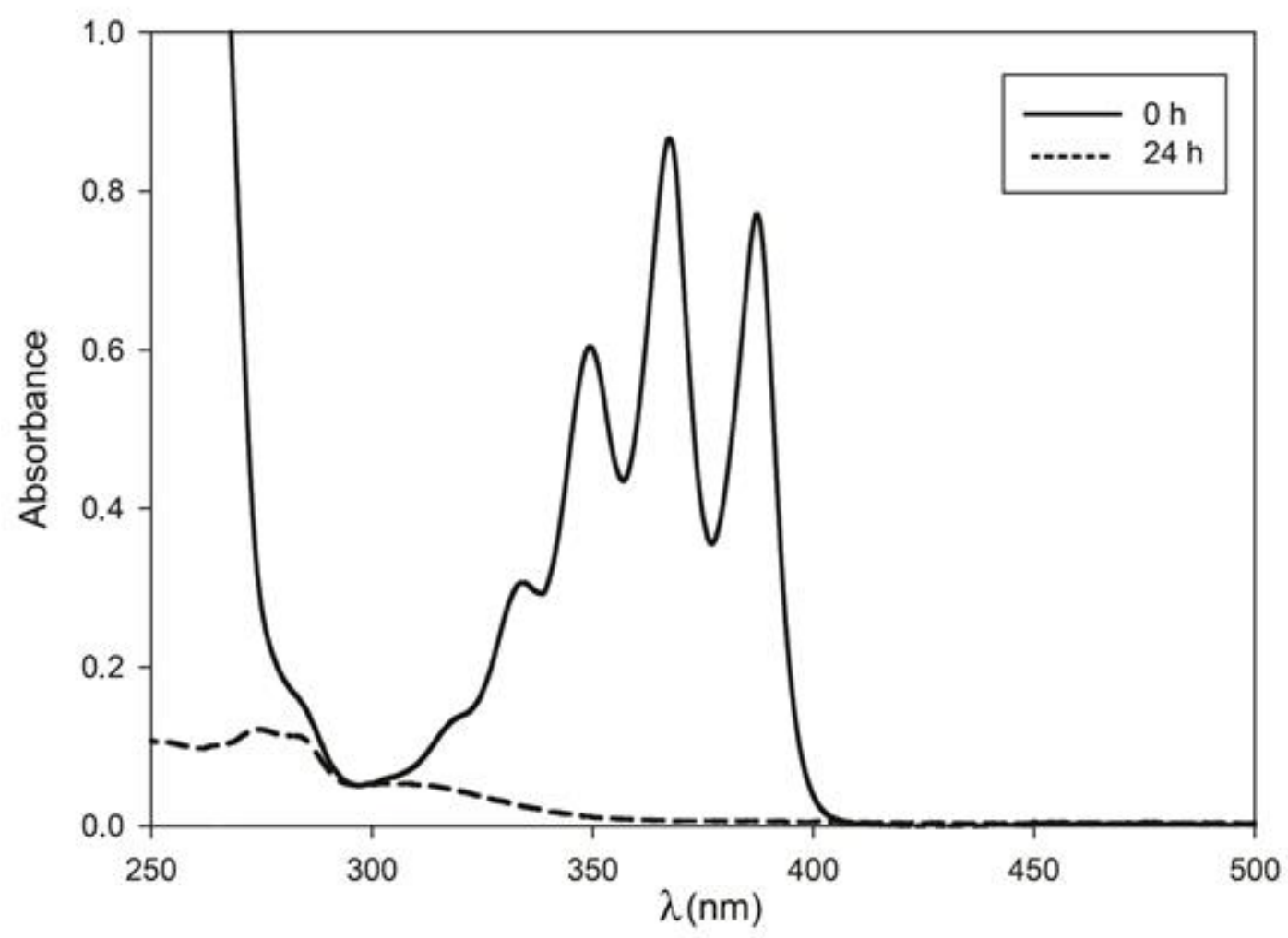

Figure 4.19: UV spectra of $\mathrm{PU}$-anthracene $(\mathrm{C} 0=0.033 \mathrm{~g} / \mathrm{L})($ at $0 \mathrm{~h})$ and $\mathrm{PU}-\mathrm{g}-2$ (at $24 \mathrm{~h})$ in $\mathrm{CH} 2 \mathrm{Cl} 2$.

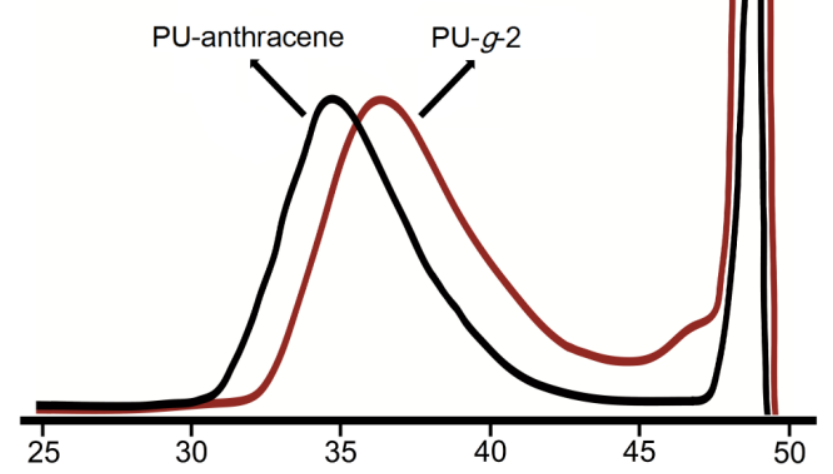

Elution Time (min)

Figure 4.20: GPC overlay of PU-anthracene and PU-g-2 (model reaction) in THF. 


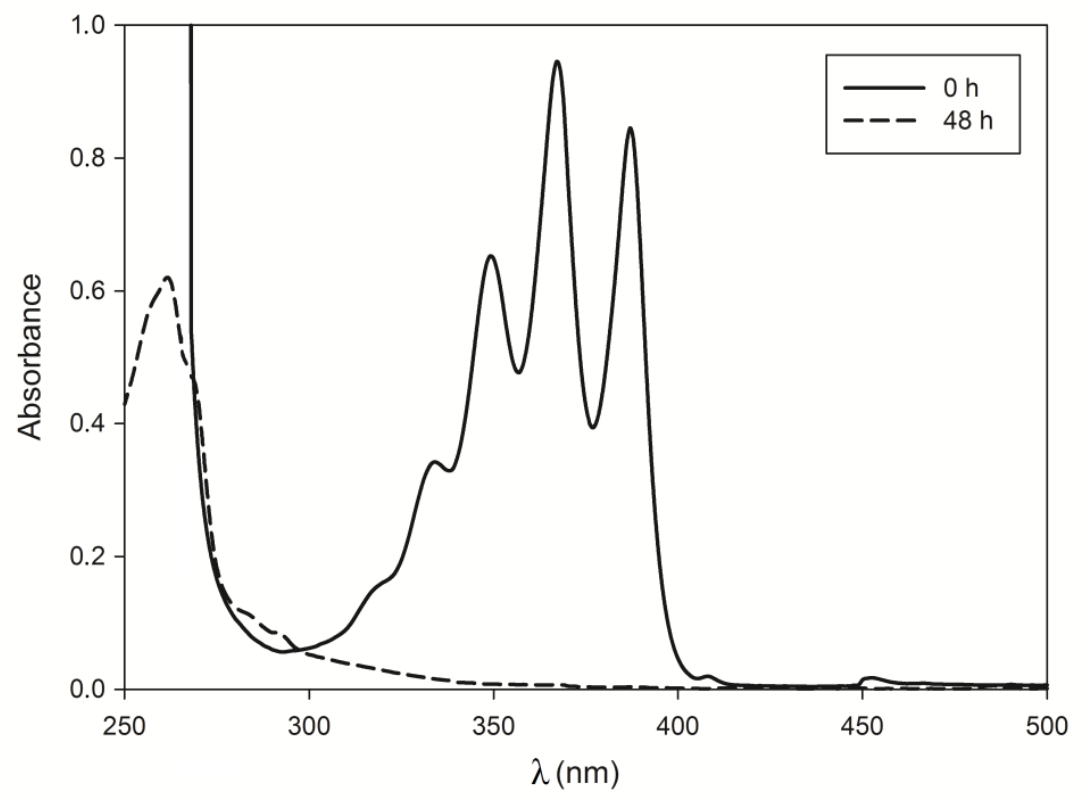

Figure 4.21: UV spectra of PU-anthracene precursor $(\mathrm{C} 0=0.033 \mathrm{~g} / \mathrm{L})($ at $0 \mathrm{~h})$, and PU-g-PMMA copolymer (at $48 \mathrm{~h}$ ) in $\mathrm{CH} 2 \mathrm{Cl} 2$.

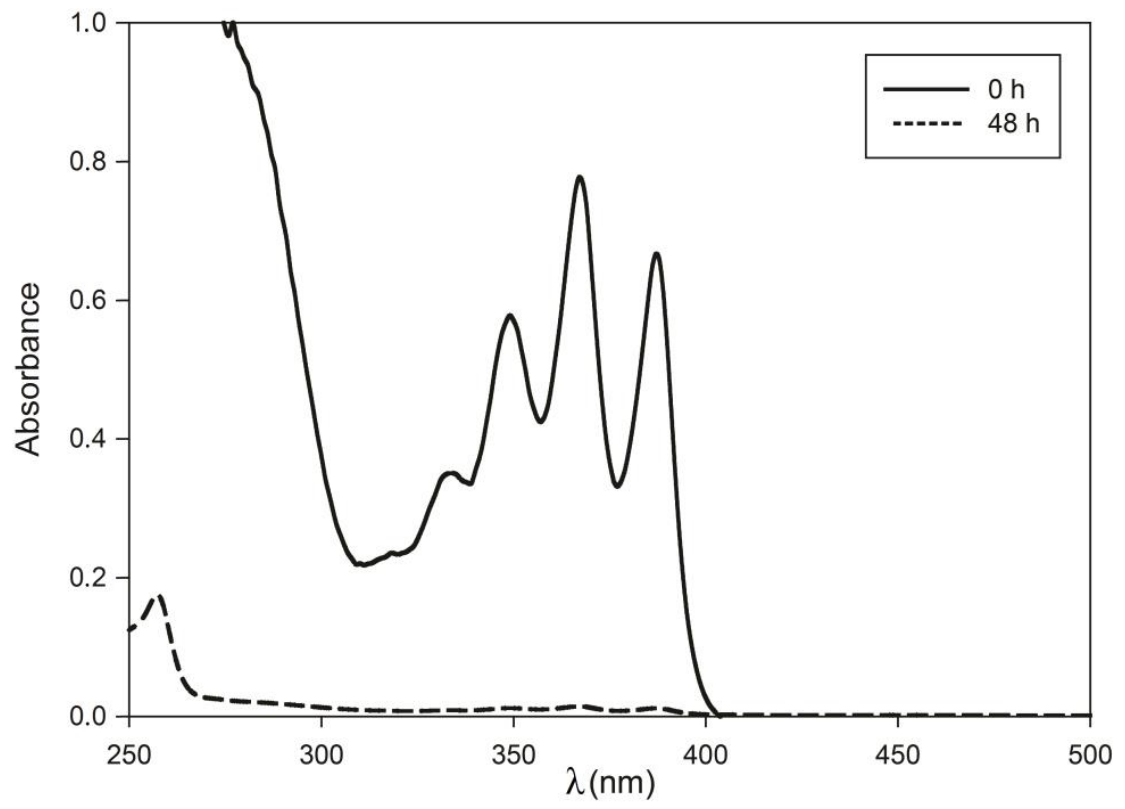

Figure 4.22: UV spectra of PU-anthracene precursor $(\mathrm{C} 0=0.033 \mathrm{~g} / \mathrm{L})($ at $0 \mathrm{~h})$ and PU-g-PEG copolymer (at $48 \mathrm{~h}$ ) in $\mathrm{CH} 2 \mathrm{Cl} 2$. 


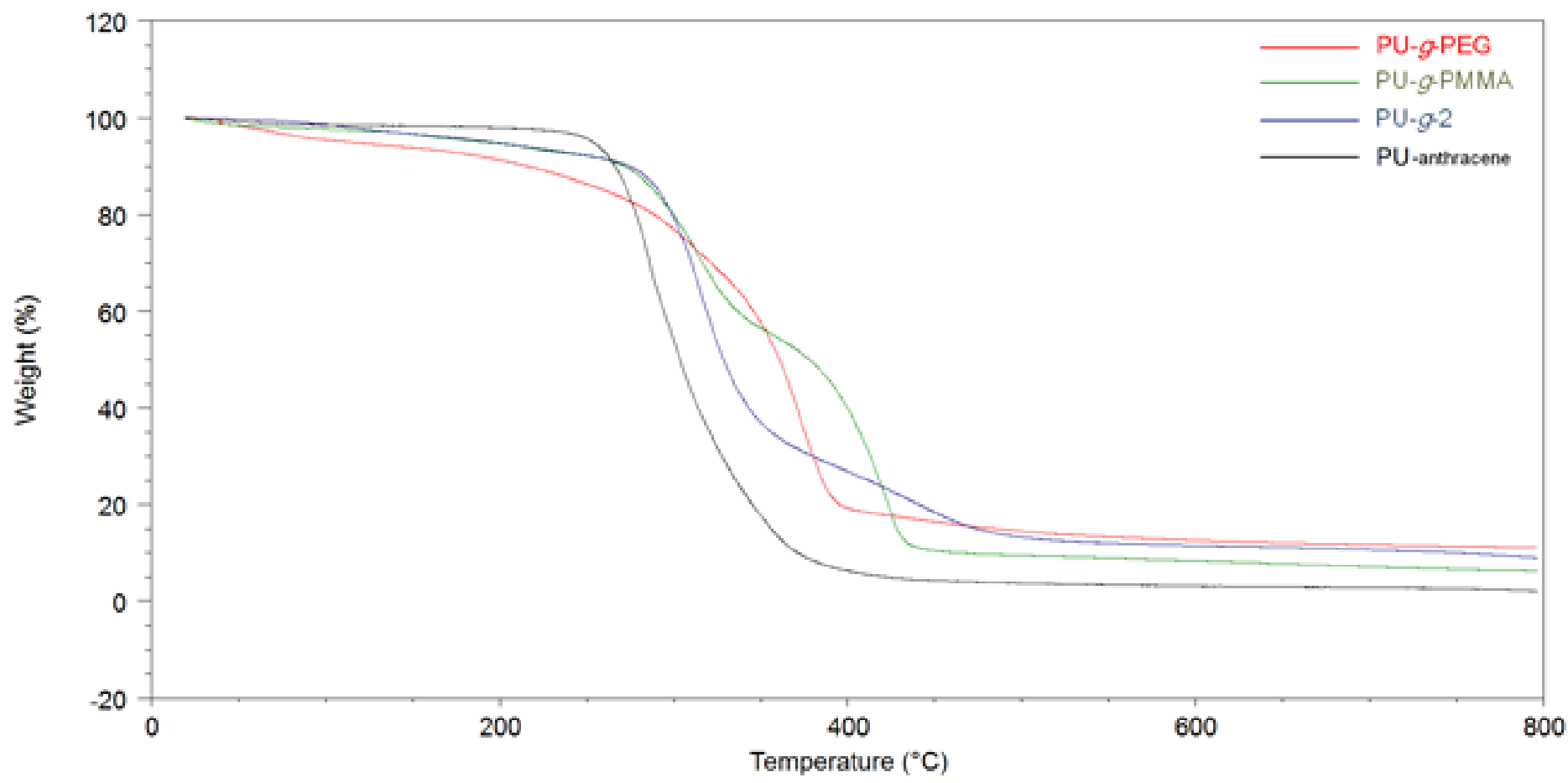

Figure 4.23: TGA traces of PU-anthracene, PU-g-2 (model reaction), PU-g-PMMA copolymer and PU-g-PEG copolymer at a heating rate of $10 \mathrm{oC} / \mathrm{min}$ under nitrogen. 


\section{CONCLUSION}

In this study, we prepared two examples of PU-graft copolymers (PU-g-PMMA and PU-g-PEG) via an incorporation of well-defined PMMA or PEG as a side chain onto the PU main backbone using Diels-Alder reaction. The linear aliphatic PU with anthracene pendant groups was prepared by reacting anthracene diol, 1 with HMDI using DBTL as catalyst in $\mathrm{CH} 2 \mathrm{Cl} 2$ at room temperature is soluble in common organic solvents $(\mathrm{CH} 2 \mathrm{Cl} 2$ and THF). We showed here for the first time that DielsAlder click reaction is an efficient synthetic approach for the incorporation of a wide variety of linear polymers into the PU main backbone in order to yield PU-graft copolymers. 


\section{REFERENCES}

[1] (a) Ulrich, H. (2003). In Encyclopedia of Polymer Science and Technology, Mark, H. (Editor)., 3rd Ed., Vol. 4, pp 26-72, John Wiley \& Sons, Inc., Hoboken, NJ; (b) G. Odian, (2004). In Principles of Polymerization, 4th Ed., John Wiley \& Sons, Inc., Hoboken, NJ.

[2] (a) N. Kihara, T. Endo. (1993). J. Polym. Sci. Part A: Polym. Chem., 31, 27652773; (b) B. Ochiai, S.-I. Sato, T. Endo, (2007). J. Polym. Sci. Part A: Polym. Chem., 45, 3408-3414; (c) V. Besse, G. Foyer, R. Auvergne, S. Caillol, B. Boutevin, J. Polym. Sci. Part A: Polym. Chem., 51, 3284-3296.

[3] (a) Z. Xie, C. Lu, X. Chen, L. Chen, X. Hu, Q. Shi, X. Jing, (2007). Eur. Polym. J., 43, 2080-2087; (b) D. V. Palaskar, A. Boyer, E. Cloutet, J.-F. Le Meins, B. Gadenne, C. Alfos, C. Farcet, H. Cramail, (2012). J. Polym. Sci. Part A: Polym. Chem., 50, 17661782; (c) G. Lligadas, J. C. Ronda, M. Galia, V. Cadiz J. (2013). Polym. Sci. Part A: Polym. Chem., 51, 2111-2124.

[4] D. Fournier, F. E. Du Prez. (2008). Macromolecules, 41, 4622-4630.

[5] L. Billiet, D. Fournier, F.E. Du Prez. (2009). Polymer, 50, 3877-3886.

[6] L. Billiet, O. Gok, A. P. Dove, A. Sanyal, L.-T. T. Nguyen, F. E. Du Prez. (2011). Macromolecules, 44, 7874-7878.

[7] (a) C. Ferris, M. V. De Paz, J. A. Galbis, (2011). J. Polym. Sci. Part A: Polym. Chem., 49, 1147-1154; (b) P. Espeel, F. Goethals, F. Driessen, L.-T. T. Nguyen, F. E. Du Prez. (2013). Polym. Chem., 4, 2449.

[8]. C. Ott, C. D. Easton, T. R. Gengenbach, S. L. McArthur, P. A. Gunatillake. (2011). Polym. Chem., 2, 2782-2784.

[9] M. Baskoa, M. Bednarek, L.-T. T. Nguyen, P. Kubisa, F.E. Du Prez. (2013). Eur. Polym. J., 49, 3573-3581.

[10] H. Sardon, J. M. W. Chan, R. J. Ono, D. Mecerreyes, J. L. Hedrick. (2014). Polym. Chem., 5, 3547-3550.

[11] P. Du, X. Liu, Z. Zheng, X. Wang, T. Joncheray, Y. Zhang. (2013). RSC $A d v ., 3,15475-15482$.

[12] Rivero, G., Nguyen, L.-T. T., Hillewaere, X. K. D., Du Prez. F. (2014). Macromolecules, 47, 2010-2018.

[13] Dag, A., Aydın, M., Durmaz, H., Hizal, G., Tunca. U., (2012). J. Polym. Sci. Part A: Polym. Chem., 50, 4476-4483.

[14] Durmaz, H., Dag, A., Erdogan, E., Demirel, A. L., Hizal, G., Tunca, U. (2010). J. Polym. Sci. Part A: Polym. Chem., 48, 99-108.

[15] (a) Durmaz, H., Dag, A., N. Cerit, O. Sirkecioglu, G. Hizal, U. Tunca. (2010). J. Polym. Sci. Part A: Polym. Chem., 48, 5982-5991; (b) A. Dag, H. Sahin, H. Durmaz, G. Hizal, U. Tunca. (2011). J. Polym. Sci. Part A: Polym. Chem., 49, 886-892; (c) Dag, A.;Durmaz, H.;Hizal, G.;Tunca, U. (2008). J Polym Sci Part A: Polym Chem,46,302-313. 
[16] Tunca, U. (2014). J. Polym. Sci. Part A: Polym. Chem., doi: 10.1002/pola.27379.

[17] Cerit, N., Cakir, N., Dag, A., Sirkecioglu, O., Durmaz, H., Hizal, G., Tunca, U., (2011). J. Polym. Sci. Part A: Polym. Chem., 49, 2850-2858.

[18] K. Pielichowski, J. Njuguna. (2005). In Thermal Degradation of Polymeric Materials, Rapra Tech. Ltd. U.K., pp 80-100.

[19] William Reusch, Michigan State U., Virtual Textbook of Organic Chemistry,

[20] Matyjaszewski, K., and Davis, T., (eds.). (2001). Handbook of Radical Polymerization, John Wiley \& Sons, New Jersey

[21] Matyjaszewski, K., Spanswick J. (2005). Controlled/Living Radical Polymerization, Material Science, 26-33.

[22] Szwarc, M. (1956). Block copolymers, Nature, 178, 1168.

[23] Quirk, R. P., Kinning, D. J., and Fetters, L. J. (1989). Comprehensive Polymer Science, Aggarwal, S. L., Vol 7, p.1, Ed. Pergamon Press, London.

[24] Matyjaszewski, K., (1995). Introduction to Living Polymerization, Living and/or Controlled Polymerization, J. Phys. Org. Chem., 8(4), 197207.

[25] Percec, V., and Tirrel, D. A. (2000). Living or Controlled ?, J. Polym. Sci., Part A: Org. Ppoly Chem., 38(10), 1705-1752.

[26] Coca, S., Paik, H., Matyjaszewski, K. (1997), Block Coplymers by Transformation of Living Ring-Opening Metathesis Polymerization into Controlled/“Living” Atom Transfer Radical Polymerization, 30, 6513-6516.

[27] Zhang, J.-F.; Ren, W.-M.; Sun, X.-K.; Meng, Y.; Du, B.-Y.; Zhang, X.-H. (2012). Macromolecules, 44 , 9882-988.

[28] (a) Lahann, J. (Editor). (2009). Click Chemistry for Biotechnology and Materials Science, Wiley: Chichester,; (b) Iha, R. K.; Wooley, K. L.; Nystrom, A. M.; Burke, D. J.; Kade, M. J.; Hawker, C. (2009). J. Chem. Rev., 109, 5620-5686.

[29] Rosen, B. M.; Wilson, C. J.; Wilson, D. A.; Peterca, M.; Imam, M. R.; Percec, V. (2009). Chem. Rev., 109, 6275-6540.

[30] Binder, W. H.; Kluger, C. (2004). Macromolecules, 37, 9321-9330.

[31] Grimaud, T.; Matyjaszewski, K. (1997). Controlled/'Living" radical polymerization of methyl methacrylate by atom transfer radical polymerization, Macromolecules, 30, 2216.

[32] Patten, T.E. and Matyjaszewski, K. (1999). Copper(I)-catalyzed atom transfer radical polymerization, Accounts of Chemical Research, 32, 895-903.

[33] Matyjaszewski, K.;Xia, J. (2001). Chem Rev., 101, 2923.

[34] Kato, M.; Kamigaito, M.; Sawamoto, M.; Higashimura, T. (1995). Macromolecules, 28, 1721.

[35] Percec, V.; Barboiu, B. (1995). Macromolecules, 28, 7970.

[36] Matyjaszewski, K.; Wang, J. S. WO Pat. 9630421, U.S. Pat. 5,763,548. 
[37] Matyjaszewski, K.; Coca, S., Gaynor, S. G.; Greszta, D.; Patten, T.E.; Wang, J.; Xia, J. WO Pat. 9718247, US. Pat. 5, 807-937.

[38] Patten, T. E.; Matyjaszewski, K. (1999). Acc. Chem. Res, 32, 895.

[39] Youqing Shen, Huadong Tang, (2004). Catalyst separation in atom transfer radical polymerization. Shijie Ding Department of Chemical and Petroleum Engineering, University of Wyoming, Laramie, WY, USA.

[40] Kato, M., Kamigaito, M., Sawamoto, M., and Higashimura, T. (1995). Polymerization of Methyl Methacrylate with the Carbon Tetrachloride/Dichlorotris(triphenylphosphine)ruthenium(II)/Methylal uminum Bis(2,6-di-tert-butylphenoxide) Initiating System: Possibility of Living Radical Polymerization, Macromolecules, 28(5), 17211723.

[41] Hoyle, C. E.; Lowe, A. B.; Bowman, C. N. (2010). Chem. Soc. Rev., 39, 13551387.

[42] Altintas, O.; Tunca, U. (2011). Chem. Asian J., 6, 2584-2591.

[43] Matyjaszewski, K., Patten, T. E., and Xia, J. (1997). Controlled/"Living" Radical Polymerization. Kinetics of the Homogeneous Atom Transfer Radical Polymerization of Styrene, J. Am. Chem. Soc., 119(4), 674680.

[44] Davis, K., O'Malley, J., Paik, H. J., and Matyjaszewski, K. (1997). Effect of the Counteranion in Atom Transfer Radical Polymerization Using Alkyl (Pseudo) Halide Initiators, Polym. Prepr. (Am. Chem. Soc., Div. Polym. Chem.), 213(320-Poly Part 2), 687.

[45] Matyjaszewski, K. and Xia, J.H. (2001). Atom transfer radical polymerization, Chemical Reviews, 101, 2921-2990.

[46] Hizal, G.; Tunca, U.; Sanyal, A. J. Polym. Sci. Part A: Polym. Chem. (2011). 49, 4103-4120.

[47] Matyjaszewski, K., Davis, K., Patten, T.E., and Wei, M.L. (1997). Observation and analysis of a slow termination process in the atom transfer radical polymerization of styrene, Tetrahedron, 53, 1532115329.

[48] Hamley, I. W. L. (1998). The Physics of block copolymers, Oxford University Press, Oxford.

[49] Sumerlin, B. S.; Vogt, A. P. (2010). Macromolecules 43, 1-13.

[50] Xia, J., Zhang, X., and Matyjaszewski, K. (2000). The Effect of Ligands on Copper-Mediated Atom Transfer Radical Polymerization, Transition Metal Catalysis in Macromolecular Design, 207-223.

[51] Matyjaszewski, K., Gnanou, Y., and Leibler, L. (2007). Macromolecular Engineering: Precise Synthesis, Materials Properties, Applications. Weinheim, Wiley-VCH.

[52] Kuran, W. (1998). Coordination Polymerization of Heterocyclic And Heterounsaturated Monomers, Prog. Polym. Sci., 23(6), 919-992. 
[53] Lundberg, R.D. and Cox, E.F. (1969). Lactones, in Ring-Opening Polymerization, Frish, K., Reegen, S., Eds, 2:247 Marcel Dekker, New York.

[54] Kricheldorf, H. R., Berl, M., and Scharnagl, N. (1988). Poly(Lactones), 9. Polymerization Mechanism of Metal Alkoxide Initiated Polymerizations of Lactide and Various Lactones, Macromolecules, 21(2), 286-293.

[55] Kowalski, A., Duda, A., and Penczek, S. (1998). Polymerization of L,LLactide Initiated by Aluminum Isopropoxide Trimer or Tetramer, Macromolecules, 31(7), 2114-2122.

[56] Schwach, G., Coudane, J., Engel, R., and Vert, M. (1998). Ring Opening Polymerization of D,L-Lactide in the Presence of Zinc Metal and Zinc Lactate, Polym. Initiated by Aluminum Isopropoxide Trimer or Tetramer, Macromolecules, Int. 46(3), 177-182.

[57] Matyjaszewski, K., Patten, T.E., and Xia, J.H. (1997). Controlled/"living" radical polymerization. Kinetics of the homogeneous atom transfer radical polymerization of styrene, Journal of the American Chemical Society, 119, 674-680.

[58] Wang, J.S. and Matyjaszewski, K. (1995). Controlled living radical polymerization - atom-transfer radical polymerization in the presence of transition-metal complexes, Journal of the American Chemical Society, 117, 5614-5615.

[59] Durmaz, H.; Sanyal, A.; Hizal, G.; Tunca, U. (2012). Polym. Chem., 3, 825835.

[60] Kolb, H. C.; Finn, M. G.; Sharpless, K. B. (2001). Angewandte Chemie, International Edition, 40, 2004-2021.

[61] Hong, S. C.; Jia, S.; Teodorescu, M.; Kowalewski, T.; Matyjaszewski, K.; Gottfried, A. C.; Brookhart, M. (2002). Journal of Polymer Science, Part A: Polymer Chemistry, 40, 2736-2749.

[62] Kaneyoshi, H.; Inoue, Y.; Matyjaszewski, K. (2005). Macromolecules, 38, 5425-5435.

[63] Neugebauer, D.; Zhang, Y.; Pakula, T.; Sheiko, S. S.; Matyjaszewski, K. (2003). Macromolecules,36, 6746-6755.

[64] Shinoda, H.; Matyjaszewski, K.; Okrasa, L.; Mierzwa, M.; Pakula, T. (2003). Macromolecules, 36, 4772-4778.

[65] Shinoda, H.; Matyjaszewski, K. (2001). Macromolecules, 34, 6243-6248.

[66] Hawker, C. J.; Mecerreyes, D.; Elce, E.; Dao, J.; Hedrick, J. L.; Barakat, I.; Dubois, P.; Jerome, R.; Volksen, I. (1997). Macromol. Chem. Phys., 198, 155-166.

[67] Matyjaszewski, K.; Beers, K. L.; Kern, A.; Gaynor, S. G. (2008). J. Polym. Sci., Part A: Polym. Chem., 36, 823-830.

[68] Lutz, J.-F.; Jahed, N.; Matyjaszewski, K. (2004). Journal of Polymer Science, Part A: Polymer Chemistry, 42, 1939-1952.

[69] Neugebauer, D.; Zhang, Y.; Pakula, T. (2006). Journal of Polymer Science, Part A: Polymer Chemistry, 44, 1347-1356.

[70] Inoue, Y.; Matsugi, T.; Kashiwa, N.; Matyjaszewski, K. (2004). Macromolecules , 37, 3651-3658. 
[71] Okrasa, L.; Pakula, T.; Inoue, Y.; Matyjaszewski, K. (2004). Colloid and Polymer Science, 282, 844-853.

[72] Kaneyoshi, H.; Inoue, Y.; Matyjaszewski, K. (2004). PMSE Preprints, 91, 41-42.

[73] Paik, H. J.; Gaynor, S. G.; Matyjaszewski, K. (1998). Macromol. Rapid Commun., 19, 47-52.

[74] Percec, V.; Asgarzadeh, F. (2001). J. Polym. Sci., Part A: Polym. Chem., 39, 1120-1135.

[75] Hong, S. C.; Pakula, T.; Matyjaszewski, K. (2001). Macromolecular Chemistry and Physics , 202, 3392-3402.

[76] Matyjaszewski, K.; Gaynor, S. G.; Coca, S. In PCT Int. Appl.; (Carnegie Mellon University, USA). WO 9840415, 1998; p 230 pp.

[77] Gao, H.; Min, K.; Matyjaszewski, K. (2007). Macromolecular Chemistry and Physics, 208, 1370-1378.

[78] Tsarevsky, N. V.; Bencherif, S. A.; Matyjaszewski, K. (2007). Macromolecules, 40, 4439-4445.

[79] Sumerlin, B. S.; Tsarevsky, N. V.; Louche, G.; Lee, R. Y.; Matyjaszewski, K. (2005). Macromolecules, 38, 7540-7545.

[80] Gao, H.; Matyjaszewski, (2007). K. Journal of the American Chemical Society, 129, 6633-6639.

[81] Fu, Q.; Liu, C.; Lin, W.; Huang, (2008). J. J. Polym. Sci., Part A: Polym. Chem., 46, 6770-6779.

[82] Kolb, H.C., Finn, M.G., and Sharpless, K.B., 2001, Click chemistry: Diverse chemical function from a few good reactions, Angewandte ChemieInternational Edition, 40, 2004-2021.

[83] C. B. Kowollik, F. E. Du Prez, P. Espeel, C. J. Hawker, T. Junkers, H. Schlaad, W. Van Camp. (2010). Angew. Chem. Int. Ed., 49, 2 - 5.

[84] Diels, O.; Alder, K.; Liebigs, J. (1928). Ann. Chem., 460, 98-122.

[85] Diels, O. and Alder, K., 1928, Synthesen in der hydroaromatischen Reihe, Justus Liebig's Annalen der Chemie, 460, 98-122.

[86] Corey, E.J., 2002, Catalytic enantioselective Diels-Alder reactions: Methods, mechanistic fundamentals, pathways, and applications, Angewandte Chemie-International Edition, 41, 1650-1667.

[87] Diels, O. and Alder, K., 1926, Über die Ursachen der Azoesterreaktion, Justus Liebig's Annalen der Chemie, 450, 237-254.

[88] L. F. Tietze and G. Kettschau, Top. Curr. Chem., 1997, 189, 1-120.

[89] Fringuelli, F. and Taticchi, A. (2002). The Diels Alder reaction : selected practical methods. Chichester, New York, Wiley.

[90] J. L. Ripoll, A. Rouessac and F. Rouessac. (1978). Tetrahedron, 34, 19-40.

[91] M.A. Tasdelen. (2011). Polym. Chem., 2011, 2, 2133.

[92] Woodward, R.B. and Hoffmann, R. (1970). The conservation of orbital symmetry. Weinheim/Bergstr, Verlag Chemie.

[93] Woodward, R.B. and Hoffmann, R. (1965). Stereochemistry of electrocyclic reactions, Journal of the American Chemical Society, 87, 395-397. 


\section{CURRICULUM VITAE}

Soykan Agar

E-mail: agars@itu.edu.tr

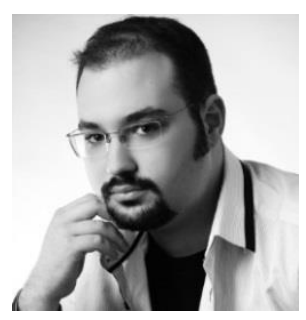

\section{\#1 - POSITIONS \& EMPLOYMENT}

Istanbul Tech. University (English Education), Istanbul, Turkey. 2012-2015

Master of Science, Chemistry Department.

$>$ Research on "Organic \& Polymer Chemistry via Click Chemistry" at Complex Macromolecular Architecture Center.

$>$ Master Degree Courses on Analytical, Organic/Polymer Chemistry \& Advanced Genetics Courses, Graduated with $2^{\text {nd }}$ degree from the Faculty of Chemistry, Jan 2015.

$>$ Research Knowledge: ATRP, ROP, ROMP, Polycondensation.

$>$ Equipment Knowledge: NMR, GPC-UV, HPLC, FTIR, DSC, TGA, Column Chromatography, TLC.

> Software Knowledge: MestRenova, ChemBioDraw 3D, TA Universal DSC Analysis, TGA Q50 Analysis, Agilent GPC/SEC, Origins, Agilent UV Chemstation, Scifinder 3D Desktop, Sigma Plot, Adobe Illustrator, Adobe Photoshop, PSP, Endnote Publication, ReadCube, Adobe Premier, Vegas Pro.

> Social Activities at the University: I edited \& created informative videos using professional movie-editing programs to explain the basics \& how to become a good archer using my movie editing/montaging techniques for the archery club members. These were watched in club meetings $\&$ were very useful for the field trainings. These kinds of activities always made me $\&$ the social groups around me quite enthusiastic \& cheerful.

Medesform Firm, Istanbul, Turkey.

2004-2015

* I was the head consultant to the boss for 11 years.

Editing and improving the english quality of the research papers that were getting sent to publishing using my experience in the "'Academic North American dialect'".

Genetic \& chemical advising.

$>$ Following, contacting \& organizing the academic \& international aspects of the jobs.

The advertising \& preparation of media speeches.

Following the scientific congresses. 
Koc University (English Education), Istanbul, Turkey.

* Bachelor of Engineering, College of Engineering Department.

$>$ Chemical Engineering \& Biological Engineering.

D Exceptional award within the Engineering faculty, in the period of Fall 2010, Vehbi Koc Scholar Award by the President of Koc University (Prof. Dr. Umran Inan).

> Graduated with high honor, Spring 2011, Dean's Honor Roll Award.

* Bachelor Thesis, College of Engineering Department.

$>$ When my senior year was arrived, for my undergraduate thesis, I designed a factory having more than a $\$ 52,000,000$ USD budget for yearly income on the basis of synthesis \& mass production of high purity (HPLC grade) dichloromethane, an important widely used solvent in both industrial \& research settings. This project required the design of various high-tech reactors, furnaces, distillation columns, chimneys, \& environmentallyresponsible waste management systems.

> Software Knowledge: Aspen Hysis, ChemCAD, Eclipse 3.3 Java, Matlab.

* Work \& Study Assistantship Program in Genetics \& Biochemistry Labs.

$>$ Research Knowledge: Proteinopathies, SNP \& Deletion scanning, Protein analysis, Bioinformatics

$>$ Equipment Knowledge: DNA electrophoresis, SDS-PAGE, HRM, PCR, Real time PCR.

$>$ Software Knowledge: GenScan.

* Social Activities at the University: I also served in the preparations of various scientific congress organizations (especially on polymer chemistry \& stem cell conferences) \& had memberships in the music/guitar \& archery clubs of my university. I was among the leading staff in the school clubs where I mostly chose to be in charge of organizing events such as bringing all together the club members to meet the stars of that profession (famous celebrity rock guitarists, archers), organizing speeches, Q\&A sessions with the celebrities, dinners, picnic potlucks, hiking in woods in the forests of Belgrade located in Istanbul.

* As I dived deeper into the ocean of chemistry \& biology, I wanted to improve myself scientifically on these marvelous coral reefs of human knowledge. Hence, I applied to, \& was accepted by, my first choice of post-secondary schools, specifically the Chemical \& Biological Engineering Department of Koc University which is well known as one of the most prestigious universities of the world. Without losing time, within my first year at the university, I began studying in the Biochemistry Labs, volunteered on the Biotechnology wing. My early efforts paid off \& later on I was promoted to join the "'work \& study program" \& recruited for Biochemistry laboratories as an undergraduate researcher since my efforts \& lab skills were appreciated by my professors. Throughout the years of my undergraduate studies, I both earned my income \& learned lot of skills in the laboratory.

* In the meantime, besides focusing on my professional area, I had the opportunity to see through the eyes of others. Throughout my undergraduate studies at Koc University, the "liberal arts system" made me focus on the economics of globalization, \& also begin to strategically evaluate history \& philosophy. These became my hobbies in my spare time \& these interests widened my general perspective to perceive the world in such a way that I have become a wellrounded, critically thinking, $\&$ appreciative person. 
* Collaborative Internship in Bio-materials Dpt, Physics of Complex Fluids Dpt \& Organic Chemistry Dpt.

$>$ In addition to advancing my academic studies, this internship provided me an opportunity to start learning to organize different research groups for the same goal \& learn German language quite a bit. The project I was involved at Mesa+ Institute required the participation of three separate research groups. I was the key figure there to organize this collaboration $\&$ hand out the duties of each different project to the undergraduate students working in different laboratories.

$>$ Research Knowledge: Cell culturing of HUVEC cells \& 3D cell imaging.

$>$ Equipment \& Software Knowledge: Confocal microscope, cell incubation, cell passaging, 2D - 3D imaging \& organelle tracking.

\section{TUPRAS - Turkish Petroleum Refineries Corp, Izmit, Turkey.}

\section{Intern in Crude Oil \& Fluid Catalytic Cracking Units.}

This was a wonderful opportunity for me to further develop leadership \& interpersonal skills that are so critical in a research setting. In TUPRAS refineries, my team-work \& collaboration abilities were again essential \& further developed. Two different units (Crude Oil Processing \& Catalytic Cracking) of the whole plant were needed to be organized to work together \& I was the bridge among them under the title of Intern Chief of Chemical Engineers \& I made some essential design changes for the plants to reduce the expense of a furnace called 5F1 of the Crude-Oil Unit.

\section{Ted College High School (English Education), Istanbul, Turkey. 2002-2005}

* Science Major, high-honor graduation.

$>$ While I was a high school student at T.E.D. Istanbul College, I began focusing my studies on chemistry \& biology, following novel projects which were published in daily Science \& Technology magazines via the informative guidance of my enthusiastic Canadian \& American teachers. In those years, experiencing different \& unique teaching styles in the classes \& laboratories dependent on more visual $\&$ brain storming techniques in the composition of classical music, increased my motivation towards chemistry \& biology.

$>$ In terms of extracurricular activities in my high school years, I worked in the environmental cleaning \& purification of 'Goksu River' project helping my high school, T.E.D. College, earn a Blue Flag, an international award given for environmental steward from the Foundation for Environmental Education in Europe. I was also one of the founding members of the carpentry club in my high school. Our club built sustainable greenhouses for my high school. As part of this project, I trained a crew of 30 club members in how to build such buildings. This project was confirmed by many high officials to allow a green future for everyone.

$>$ I also was the captain of the official basketball team of T.E.D. in the years of $2002-2005$, playing in both the center \& point guard positions. Our team earned a silver medal in the national basketball tournaments between the years of 2003-2004.

$>$ Finally, I had memberships in the table-tennis \& chess clubs throughout my high school years. 


\title{
\#2 - HONORS/AWARDS
}

* Istanbul Technical University, $2^{\text {nd }}$ degree in graduation

* Koc University, High Honor graduation, Dean's Honor Roll Award

* Vehbi Koc Scholar Award by the President of Koc University

Exceptional Award, Crystal Award Plaque

* Koc University, Dean's Honor Roll Award

* Koc University, Undergraduate Work \& Study Assistantship in Biochemistry

\section{\#3 - LANGUAGES}

ENGLISH (Upper Advanced level at academic speaking, writing \& reading)

$>$ I.B.T. (Internet Based TOEFL) : Overall: 99, TWE: 29/30

* TURKISH (Upper Advanced level at academic speaking, writing \& reading)

* GERMAN (Pre-Intermediate level at reading, speaking \& writing)

\section{\#4 - EXTRACURRICULAR ACTIVITIES}

* Archery Club Member at Istanbul Technical University

* Scientific Congress Organizations at Koc University

* Music Club Member of Koc University, playing acoustic guitar in the band

* I.A.E.S.T.E. (The International Assoc. for the Exchange of Tech. Experience)

* Sustainable Greenhouse Building Project

* Basketball Team Member (Position: Center, PG) at Ted College

* F.E.E.E. (Foundation for Environmental Education in Europe)

I worked on the environmental cleaning \& purification of the streams \& rivers, especially on Goksu Stream, located in Istanbul Bosphorus, earned blue flag for this international project.

\section{\#5 - HOBBIES \& PERSONAL}

\author{
* Archery \\ * Philosophy \\ * Playing Classical \& Acoustic Guitar \\ * History of Science \\ * Cinematography, movie editing techniques using Adobe Premier, Vegas Pro, \\ Movie Maker Papajohn \\ * 19.12.1988, B (automobile) driving license, non-smoker
}




\section{\#6 - PUBLICATIONS}

1) Soykan Agar, Hakan Durmaz, Ufuk Saim Gunay, Gurkan Hizal \& Umit Tunca, Polymer grafting onto polyurethane backbone via Diels-Alder reaction, J. Polym. Sci. Part A: Polym. Chem., 2014, vol. 53, issue 4, p 521-527, doi: 10.1002/pola.27466.

http://onlinelibrary.wiley.com/doi/10.1002/pola.27466/abstract

- Explanation: I studied my master degree thesis \& published this paper mentioned above at Istanbul Technical University within the "Complex Macromolecular Structure Center". The professors of the center has great $\mathrm{H}$ indices \& high impact factor values for the publications they make \& are among the top ten papers published in the "Journal of Polymer Science of Wiley". Within that research center, I focused on graft \& brush copolymers; I synthesized the appropriate allyl \& anthrecene pendant urethane monomers \& polymerized them with various methods including condensation polymerization, ATRP, ROP \& ROMP to get the polymer backbone which later on they can be branched/grafted with Click chemistry.

* My contributions: For this research paper, my job was to synthesize all the chemicals, characterize them (NMR, GPC, HPLC, UV, FTIR, TGA, DSC) \& when advise was needed, asking questions to my lab supervisor Assoc. Prof. Hakan Durmaz \& Prof Umit Tunca - Prof. Gurkan Hizal.

* Aim of the paper: My aim was to synthesize polyurethane backbones, forming its grafts via Diels-Alder chemistry \& observing the increase in the heat resistance capabilities of the grafted co-polymers. For the synthesis, green chemistry subtitutes were used as much as it could have done. Three different branched grafts of Pu-g-PMMA, PU-g-PEG \& PU-g-adduct alcohol are succefully synthesized $\&$ characterized due to the great help of Click Chemistry Diels-Alder, the yields were very high, up to 93-98\%. Plasticizing / hardening effects were seen when PMMA was incorporated in PU structure. While PMMA increasing the elasticity \& toughness of the graft, PEG introduced hydrophilic property \& elongation at break point.

2) Suna Lahut, Burcak Ozes, Soykan Agar, A. Nazli Basak, TDP-43 Proteinopathies: A New Player in Neurodegenerative Diseases with Defective Protein Folding, Turkish Journal of Neurology, 2012, vol. 18(1), p 1-10, doi:10.4274/Tnd.58561. http://www.journalagent.com/tjn/pdfs/TJN_18_1_1_10.pdf

Explanation: During my scientific preparation courses semesters before my master degree at I.T.U., I studied on different projects, mainly consisting of finding discoveriers by biochemical mechanisms to the neurobiological \& neurodegenerative diseases. Among them, I also studied a little bioinformatics on Becker Muscle Syndrome, ALS \& Parkinson's Diseases. While working on those, I got chosen to study in a second project by the admiration of professors to use my chemistry knowledge on Genetics for the proteinopathies. I then published a review paper concerning TDP-43 proteinopathies.

* My contributions: I was the co-author for the paper published, where each of us had different sections to write \& compare our cumulative knowledge at the end. I 
was responsible for the writing of, TDP 43 Gene-Protein \& Aggregations section $\&$ its relation with the neurodegeneration sections \& the summary/abstract.

* Aim of the paper: It was written to comprehensively understand how TDP-43 inclusion bodies \& its aggregations within the cell leads to the neurodegenerative diseases. Stress, aging \& the chronic expression of misfolded proteins challenge the proteostasis machinery $\&$ the vitality of the cell. There is increasing evidence that the accumulation of damaged proteins not only has direct consequences on the efficiency \& fidelity of cellular processes but also, when not corrected, that they initiate a cascade of dysfunction, which in humans is associated with a plethora of diseases of protein conformation, referred to as proteinopathies. Alzheimer's Disease (AD), Parkinson's Disease (PD), Huntington's Disease (HD), Amyotrophic Lateral Sclerosis (ALS), cancer \& diabetes, whose frequencies have drastically increased in countries with aging populations, are all consequences of misfolded proteins. This paper focuses on TDP-43, which excelled as a key protein in neurodegenerative processes because of its association with different diseases, especially with ALS \& Frontotemporal Lobar Dementia (FTLD), the two best studied examples of TDP-43 proteinopathies (Turkish Journal of Neurology 2012; 18:1-10). 